\title{
Peptide Tethering: Pocket-Directed Fragment Screening for Peptidomimetic Inhibitor Discovery
}

\author{
Ashley E. Modell, Frank Marrone III, Nihar R. Panigrahi, Yingkai Zhang, and Paramjit S. Arora* \\ Department of Chemistry, New York University, 100 Washington Square East, New York, NY, 10003 \\ *arora@nyu.edu
}

\section{Table of Contents:}

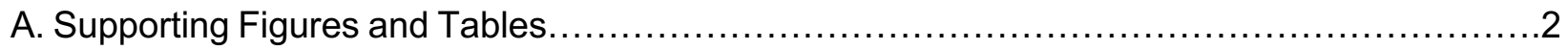

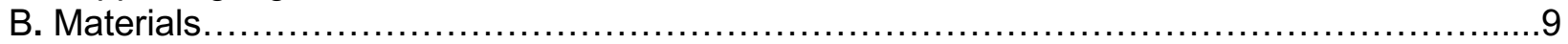

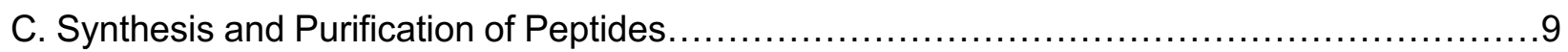

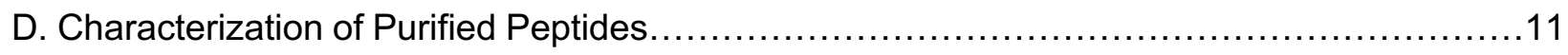

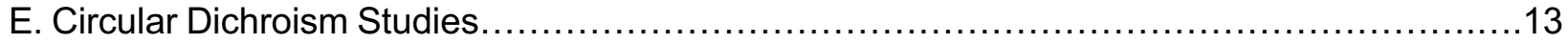

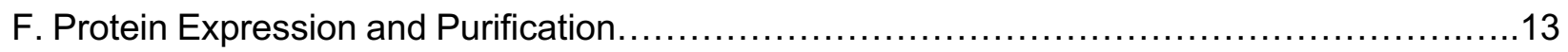

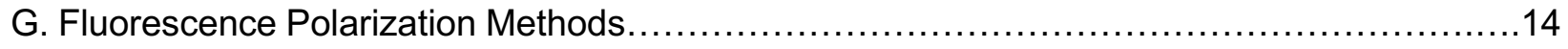

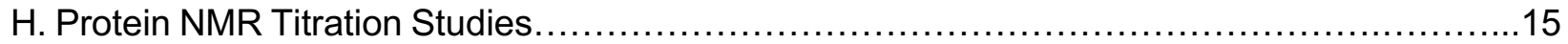

I. Synthesis, Purification, and Characterization of Small Molecules.............................16

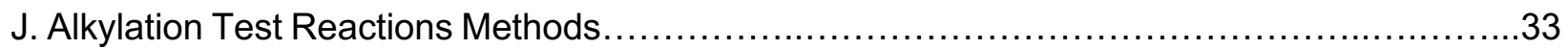

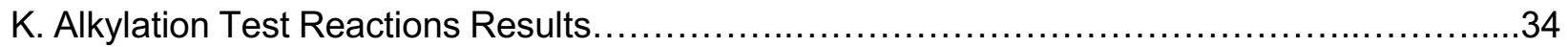

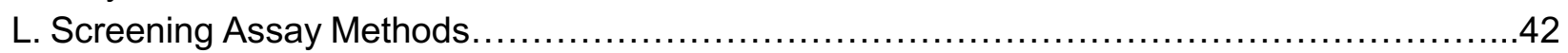

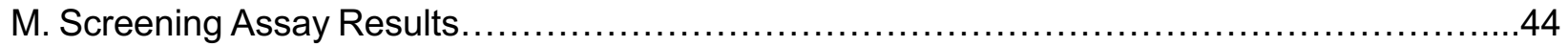

N. Designs of Cell-Stable Analogues from Screening Hits . . . . . .

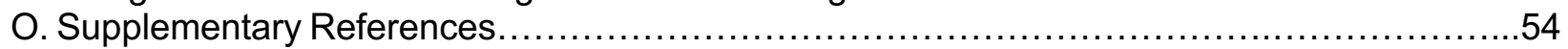




\section{A. Supporting Figures and Tables}

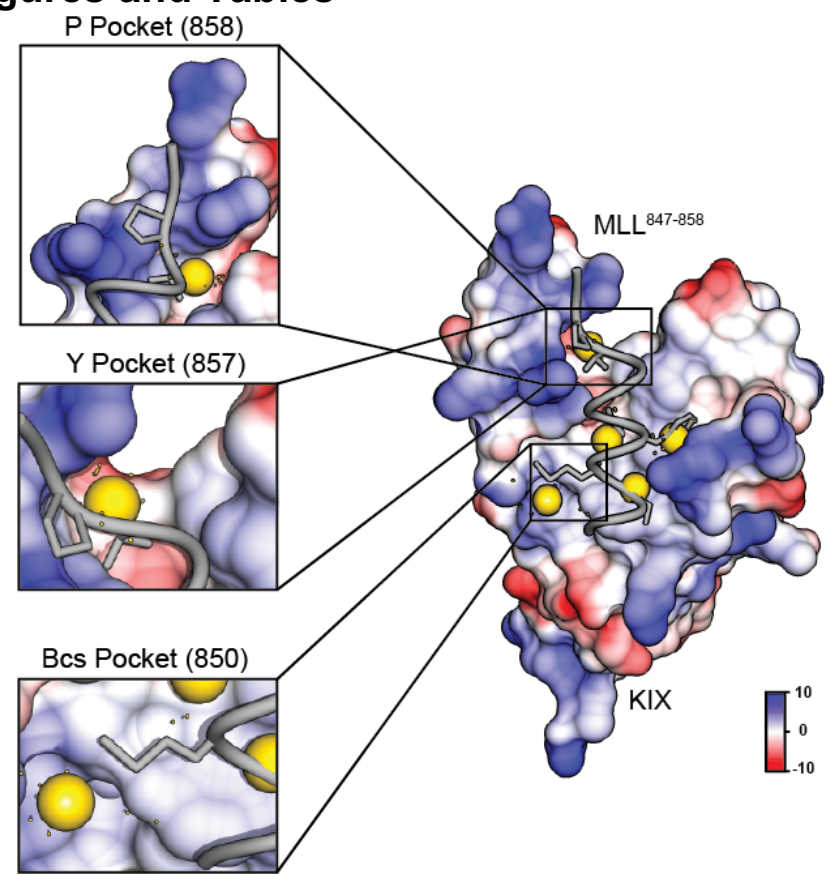

Figure S1: Electrostatic map of KIX highlighting the pockets screened. MLL ${ }^{847-858}$ ribbon, docked to KIX, shown in electrostatic surface. Pockets screened are highlighted. The Bcs pocket is hydrophobic as well as the surrounding residues around the $\mathrm{Y}$ pocket, whereas the $\mathrm{P}$ pocket is surrounded by a positive patch on KIX. PDB 2AGH.

Table S1: Summary of binding constants for HBS derivatives. The MLL and unconstrained compounds $\left({ }^{\ddagger}\right)$ are the same compounds tested and reported in [1]. Several mutations were made to identify HBS I as the best binder. Binding constants determined by a fluorescence polarization competition assay.

\begin{tabular}{|c|c|c|c|c|c|c|c|c|c|c|c|c|c|c|c|c|}
\hline Compound & \multicolumn{15}{|c|}{ Sequence } & \multirow{2}{*}{$\frac{K_{\mathrm{i}}(\mu \mathrm{M})}{>1000^{\ddagger}}$} \\
\hline$M L L^{847-858 \ddagger}$ & Ac- & $\mathrm{s}$ & $\mathrm{D}$ & 1 & $M$ & $\mathrm{D}$ & $\mathrm{F}$ & V & $\mathrm{L}$ & $\mathrm{K}$ & $\mathrm{N}$ & $\mathrm{T}$ & $\mathrm{P}$ & $-\mathrm{NH}_{2}$ & & \\
\hline Peptide $\mathrm{I}^{\ddagger}$ & Ac- & $\mathrm{S}$ & $\mathrm{D}$ & 1 & Bcs & $\mathrm{D}$ & $2 \mathrm{meF}$ & 1 & L & $\mathrm{K}$ & $\mathrm{N}$ & $Y$ & $P$ & $-\mathrm{OH}$ & & $22 \pm 8^{\ddagger}$ \\
\hline Peptide I-NH ${ }_{2}^{\ddagger}$ & Ac- & $S$ & $\mathrm{D}$ & I & Bcs & $\mathrm{D}$ & $2 \mathrm{meF}$ & 1 & $\mathrm{~L}$ & $\mathrm{~K}$ & $\mathrm{~N}$ & $Y$ & $\mathrm{P}$ & $-\mathrm{NH}_{2}$ & & $20 \pm 26^{\ddagger}$ \\
\hline HBS 0 & $x$ & $S$ & $\mathrm{D}$ & $\mathrm{G}^{*}$ & Bcs & $\mathrm{D}$ & $2 \mathrm{meF}$ & I & $\mathrm{L}$ & $\mathrm{K}$ & $\mathrm{N}$ & $Y$ & $\mathrm{P}$ & $-\mathrm{NH}_{2}$ & & $28 \pm 10$ \\
\hline HBS I & $x$ & $S$ & $\mathrm{D}$ & $\mathrm{G}^{*}$ & Bcs & $\mathrm{D}$ & $2 \mathrm{meF}$ & I & $\mathrm{L}$ & $\mathrm{K}$ & $\mathrm{N}$ & $Y$ & $P$ & W & $-\mathrm{NH}_{2}$ & $13 \pm 3$ \\
\hline
\end{tabular}

All single letter amino acid codes are used above in addition to the following abbreviations: Ac = Acyl cap; $\mathrm{X}=$ Pentenoic Acid; Bcs = Benzylcysteine; $2 \mathrm{meF}=2$-methyl phenylalanine; $\mathrm{G}^{*}=$ $\mathrm{N}$-allyl glycine 
A) HBS I_850_Screen*

B) HBS I_857_Screen*

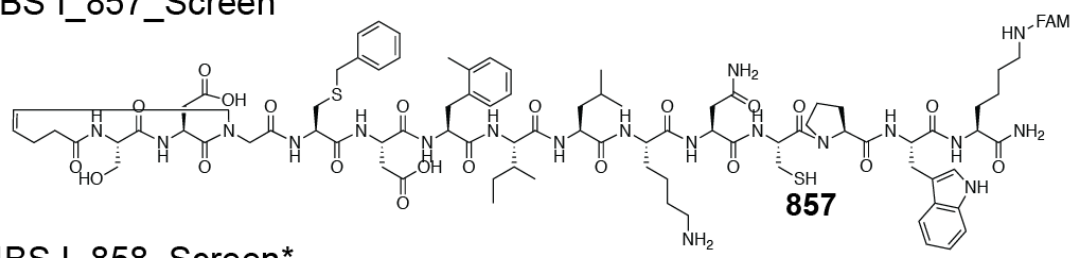

C) HBS I_858_Screen*

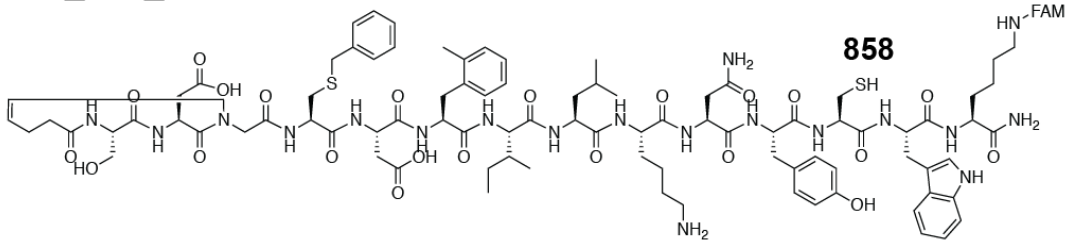

Figure S2: Peptides used for screening in this study: A) HBS I_850_Screen*to screen at the Bcs pocket, B) HBS I_857_Screen* to screen at the Y pocket, and C) HBS I_858_Screen* to screen at the $\mathrm{P}$ pocket. 


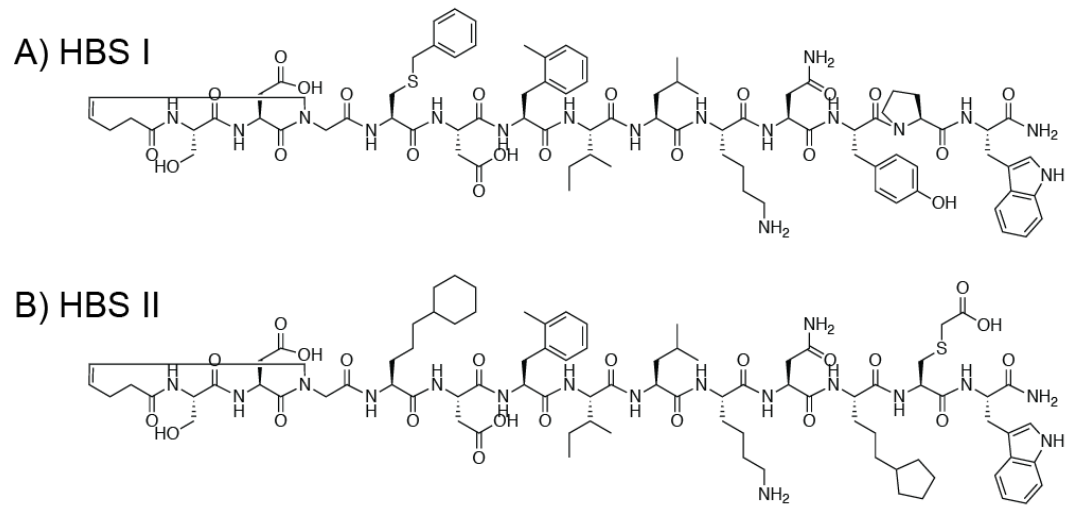

C) HBS I*

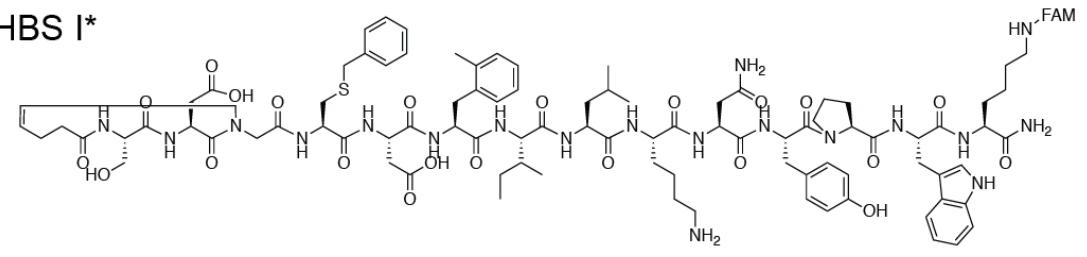

D) HBS II*

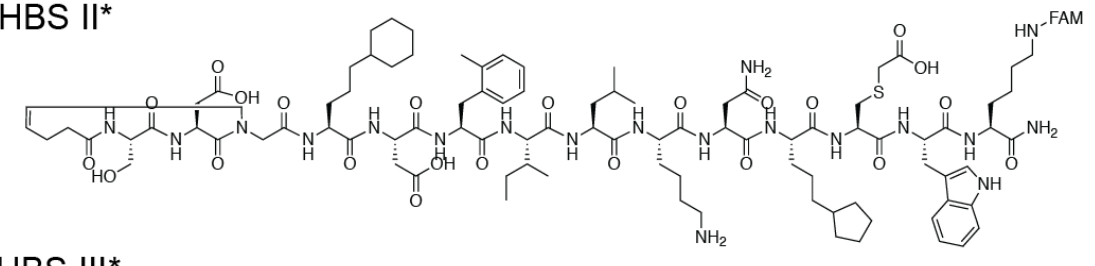

E) HBS III*

F) HBS IV*
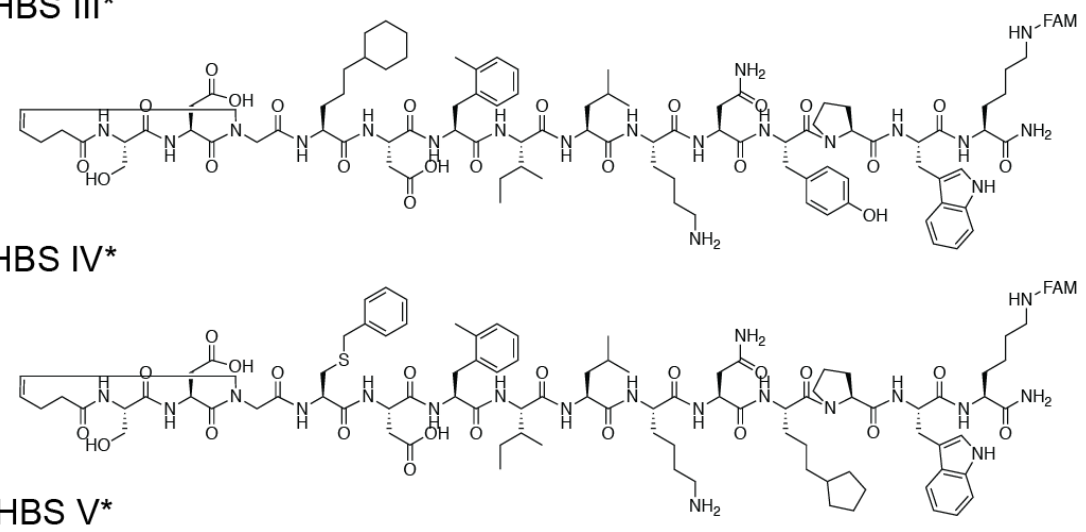

G) HBS V*

H) HBS VI*

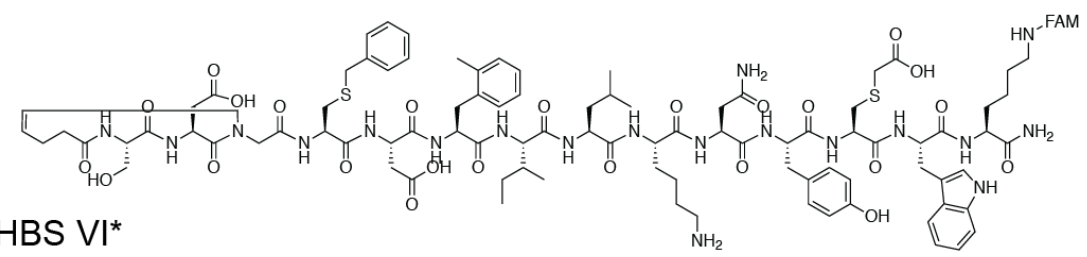

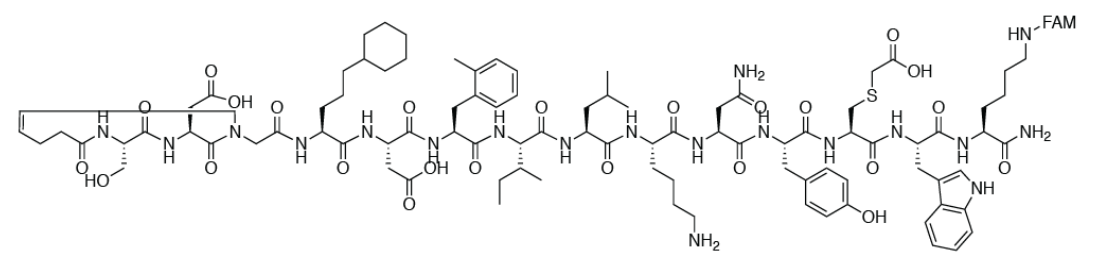

Figure S3: Structures of peptides used in this study. Baseline HBS (HBS I), optimized HBS (HBS II), and peptides containing fragment hits at one position (HBS III-V*), two positions (HBS VI*). * denotes fluorescently labeled. 
Table S2: Summary of binding affinities with hits from the screen. Data is shown in Fig 5 in the manuscript. Binding Constants determined by FP.

\begin{tabular}{|l|c|}
\hline Peptide & $\boldsymbol{K}_{\mathbf{d}}(\boldsymbol{\mu M})$ \\
\hline $\mathrm{HBS} \mathrm{I}^{*}$ & $51 \pm 18$ \\
\hline $\mathrm{HBS} \mathrm{II}^{*}$ & $17 \pm 5$ \\
\hline $\mathrm{HBS} \mathrm{IV}^{*}$ & $13 \pm 3$ \\
\hline $\mathrm{HBS} \mathrm{V}^{*}$ & $21 \pm 5$ \\
\hline $\mathrm{HBS} \mathrm{VI}^{*}$ & $7.4 \pm 1.4$ \\
\hline $\mathrm{HBS} \mathrm{II}^{*}$ & $2.0 \pm 0.6$ \\
\hline
\end{tabular}

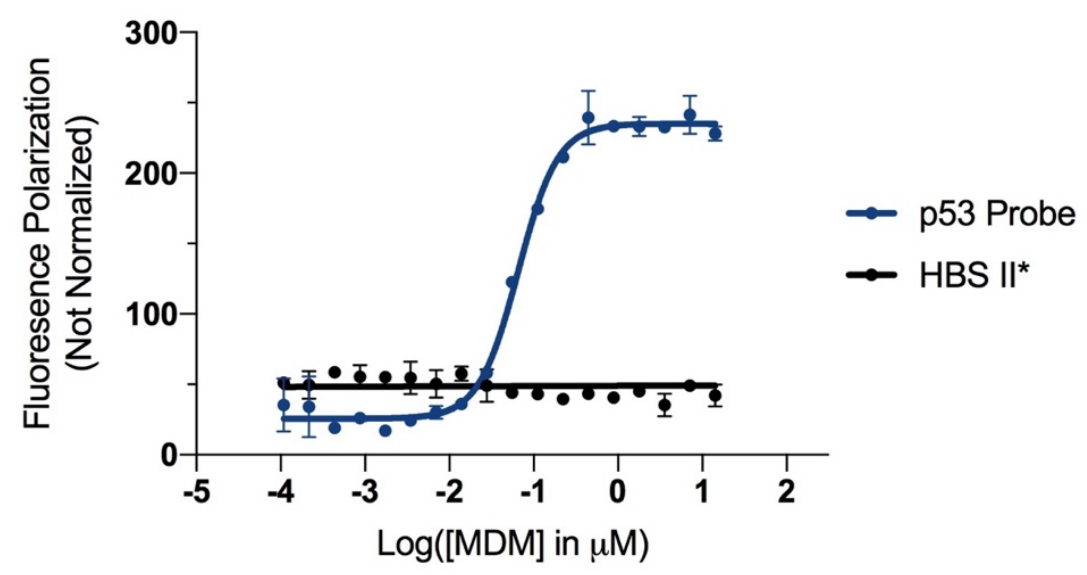

Figure S4: Investigating selectivity of the HBS $\mathrm{II}^{*}$ peptide against MDM2. Fluorescence polarization direct binding studies with the p53 Probe from [2] (known binder to MDM2) and $\mathrm{HBSII}^{*}$ fluorescently labeled peptide to MDM2. $\mathrm{K}_{\mathrm{D}}$ p53 Probe for MDM2 is $47 \pm 10 \mathrm{nM}$. $\mathrm{K}_{\mathrm{D}} \mathrm{HBS}$ II* for MDM2 is $>15 \mu \mathrm{M}$. 
A)

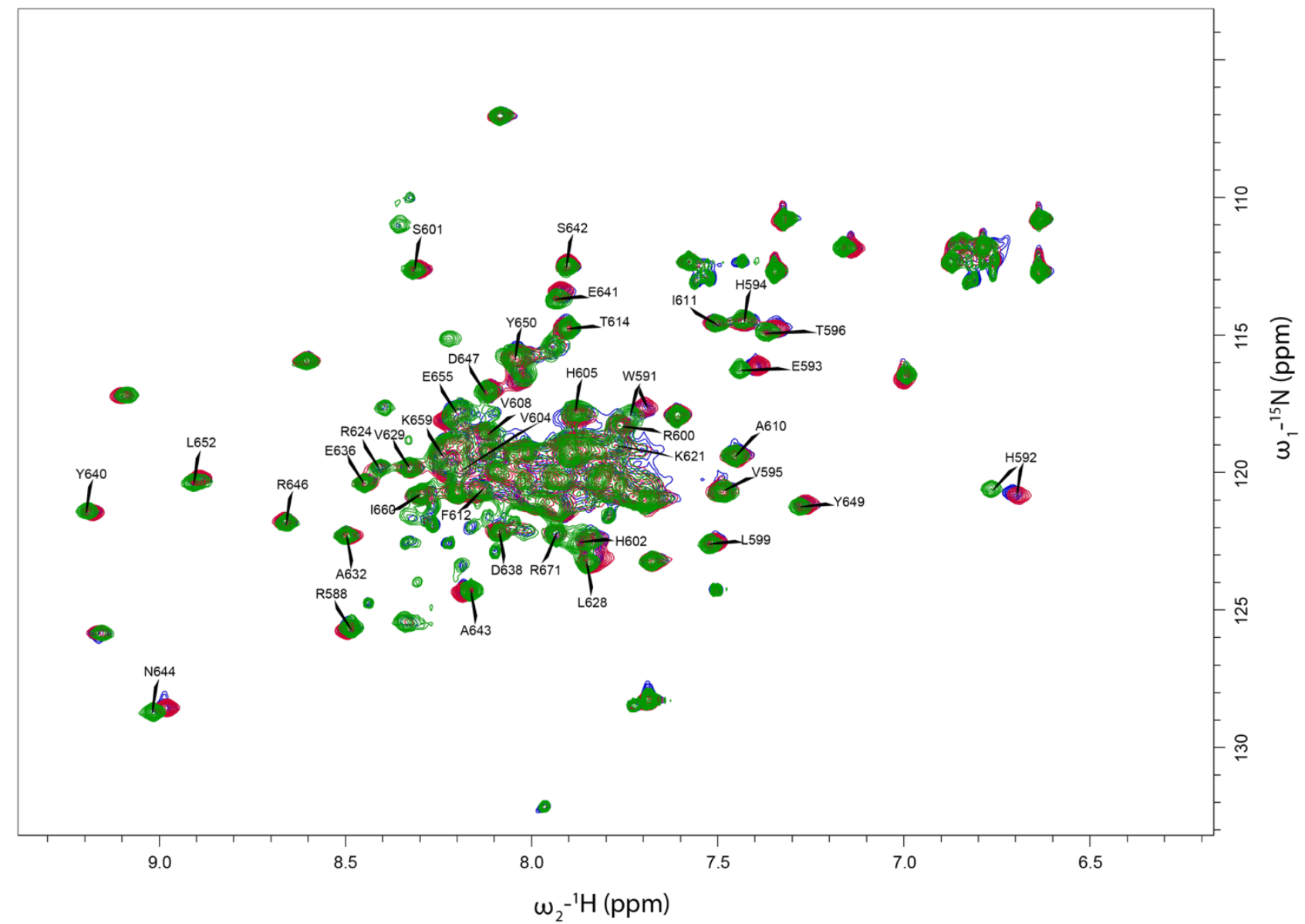

Figure S5: A) NMR shifts mapped on KIX in the presence of HBS II at 0, 0.5 and 1 molar equivalents. 
B)

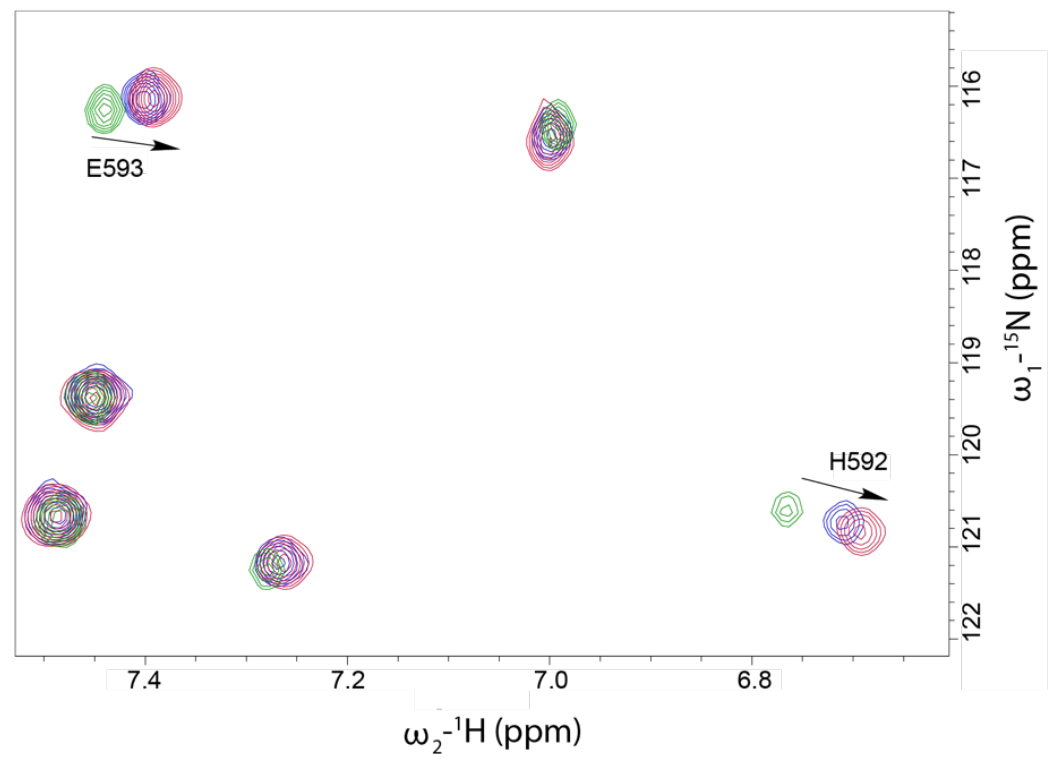

C)

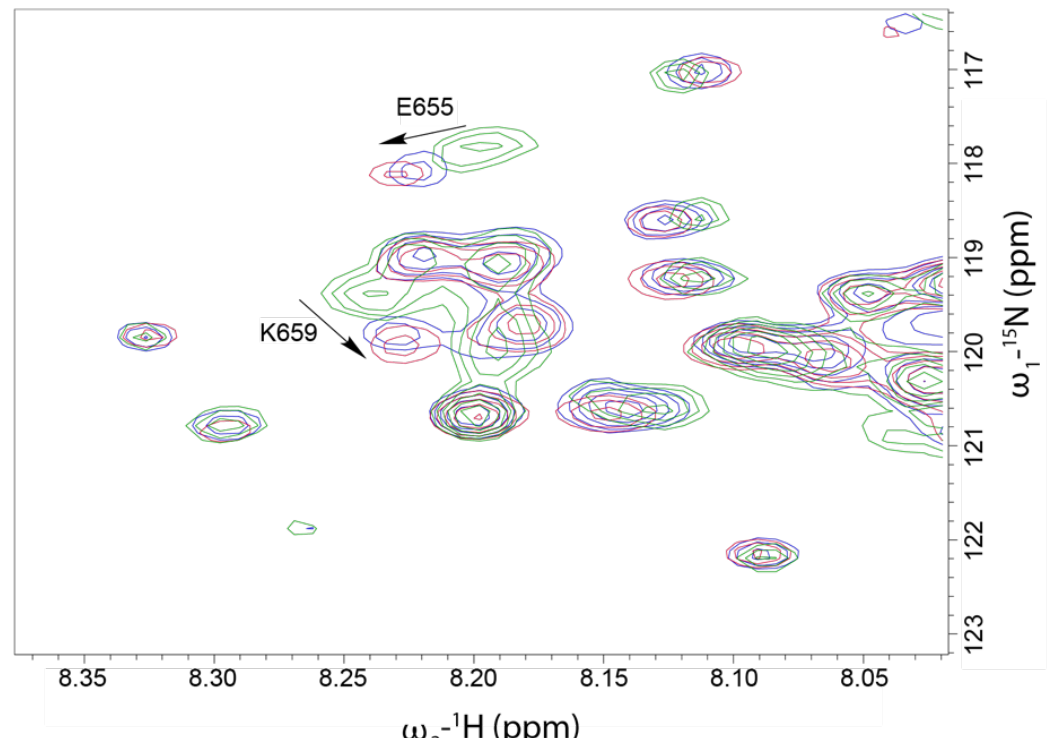

Figure S5. Cont. B) Unidirectional shifts of E593, H592, and C) E655 and K659 are shown. Color codes: Green $=$ Apo, Blue $=0.5$ molar eq., Red $=1$ molar eq. 
Table S3: Summary of NMR Shifts in the presence of HBS II.

\begin{tabular}{|c|c|c|}
\hline Residue & Position & Shift \\
\hline R & 588 & 0.031 \\
\hline W & 591 & 0.094 \\
\hline H & 592 & 0.101 \\
\hline E & 593 & 0.049 \\
\hline H & 594 & 0.043 \\
\hline V & 595 & 0.006 \\
\hline T & 596 & 0.032 \\
\hline L & 599 & 0.014 \\
\hline R & 600 & 0.009 \\
\hline S & 601 & 0.015 \\
\hline V & 604 & 0.053 \\
\hline H & 605 & 0.054 \\
\hline L & 607 & 0.007 \\
\hline V & 608 & 0.028 \\
\hline A & 610 & 0.009 \\
\hline I & 611 & 0.012 \\
\hline F & 612 & 0.026 \\
\hline T & 614 & 0.022 \\
\hline D & 616 & 0.008 \\
\hline A & 618 & 0.012 \\
\hline A & 619 & 0.007 \\
\hline L & 620 & 0.003 \\
\hline K & 621 & 0.028 \\
\hline R & 624 & 0.009 \\
\hline L & 628 & 0.008 \\
\hline V & 629 & 0.004 \\
\hline Y & 630 & 0.006 \\
\hline & 631 & 0.009 \\
\hline
\end{tabular}

\begin{tabular}{|c|c|c|}
\hline Residue & Position & Shift \\
\hline $\mathrm{R}$ & 588 & 0.031 \\
\hline $\mathrm{K}$ & 633 & 0.002 \\
\hline $\mathrm{K}$ & 634 & 0.009 \\
\hline$E$ & 636 & 0.002 \\
\hline$D$ & 638 & 0.007 \\
\hline$M$ & 639 & 0.012 \\
\hline $\mathrm{Y}$ & 640 & 0.026 \\
\hline$E$ & 641 & 0.076 \\
\hline$S$ & 642 & 0.005 \\
\hline A & 643 & 0.029 \\
\hline $\mathrm{N}$ & 644 & 0.047 \\
\hline $\mathrm{R}$ & 646 & 0.009 \\
\hline $\mathrm{D}$ & 647 & 0.008 \\
\hline$Y$ & 649 & 0.017 \\
\hline$Y$ & 650 & 0.012 \\
\hline $\mathrm{H}$ & 651 & 0.019 \\
\hline $\mathrm{L}$ & 652 & 0.038 \\
\hline $\mathrm{L}$ & 653 & 0.005 \\
\hline A & 654 & 0.018 \\
\hline$E$ & 655 & 0.071 \\
\hline 1 & 657 & 0.013 \\
\hline $\mathrm{K}$ & 659 & 0.155 \\
\hline 1 & 660 & 0.027 \\
\hline Q & 661 & 0.014 \\
\hline $\mathrm{K}$ & 662 & 0.009 \\
\hline$E$ & 663 & 0.005 \\
\hline$E$ & 666 & 0.018 \\
\hline $\mathrm{R}$ & 669 & 0.005 \\
\hline
\end{tabular}




\section{B. Materials}

Commercial grade solvents and reagents were used without further purification. All reagents were purchased from Chemlmpex, TCl, Sigma, Aldrich, Sigma-Aldrich, Alfa Aesar, VWR, Anaspec, ThermoScientific, Novabiochem, GyrosProtein Technologies, Combi-Blocks, Matrix Scientific, Enamine, and Acros. Bioexpress Media (10X) was purchased from Cambridge Isotopes.

\section{Synthesis and Purification of Peptides}

Solid-Phase Peptide Synthesis: High loading Rink Amide MBHA $(0.80 \mathrm{mmol} / \mathrm{g})$ was used for the HBS derivatives. Low loading Rink Amide MBHA $(0.27 \mathrm{mmol} / \mathrm{g})$ was used for peptides with Cterminal 5-carboxyfluoroscien additions. Standard Fmoc- synthesis was used and the resin was sufficiently washed in between steps with DMF, DCM, MeOH, DMF, DCM with 5 column volumes each. Synthesized amino acid monomers were coupled by hand using either 3 or 4 eq. of Amino Acid/HOAt/DIC in DMF overnight.

For HBS derivatives containing glycine at the bridge: peptides were synthesized until the bridge, followed by coupling of Nosyl-N(allyl)-glycine-OH which has been previously synthesized and described [3]. For HBS derivatives containing alternative residues at the bridge: peptides were synthesized until the bridgehead carbon, protected with nosyl chloride before performing a mitsunobu reaction with allyl alcohol as described [4]. The nosyl group was then deprotected using 10 equivalents of thiophenol and 10 equivalents of triethylamine in DMF for 2 hours. Secondary amine couplings were performed overnight with 10/10/10 equivalents of AA/HOAT/DIC in DMF. Standard Fmoc- coupling was used to complete the bis-olefin.

All other peptides were synthesized using standard Fmoc-solid phases synthesis using a Prelude $X$ Protein Technologies synthesizer until the bis olefin. Nosyl deprotection of nosyl glycine was carried out on the synthesizer using $120 \mathrm{mM}$ DBU and $100 \mathrm{mM} \beta$-mercaptoethanol in DMF. The Fmoc- deprotection solution (20\% Piperidine/DMF) was supplemented with $0.1 \mathrm{M} \mathrm{HOBt}$ to prevent aspartimide formation [5].

For all peptides, ring closing metathesis was performed in the microwave on $0.1 \mathrm{mmol}$ scales with $3 \mathrm{mLs}$ of dry DCE, $0.20 \%$ of Hoveyda-Grubbs II using $120^{\circ} \mathrm{C}$ for 12 minutes at $150 \mathrm{~W}$ power (Scheme S1).

After ring closing metathesis, Lys(Mtt)-containing peptides were deprotected using 1.5\% TFA, 5\% TIPS in DCM for 5 minutes and repeated for a total of 5 times. The resin was then treated with $5 \%$ DIEA in DMF for 5 minutes each for a total of 3 times. 4 equivalents of 5 -carboxyfluoroscein (5-FAM) was activated with 4 equivalents of HBTU and 8 equivalents of DIEA in DMF and was then added to the resin. The 5-FAM was at a $0.1 \mathrm{M}$ final concentration. The reaction proceeded overnight and was confirmed by MALDI-TOF (Scheme S2).

All peptides were cleaved from the resin and globally deprotected by applying a solution of trifluoroacetic acid/TIPS/water (95/2.5/2.5) for 2 hours at room temperature or trifluoroacetic acid/thioanisole/EDT/anisole (90/5/3/2) for peptides with free thiols. The resin was filtered and the peptide was concentrated in vacuo. The pellet was precipitated with cold diethyl ether and dried under nitrogen gas. Reversed-phase HPLC using a gradient of acetonitrile in water supplemented with $0.1 \%$ TFA was performed. Each peptide was lyophilized and yielded a white to off-white powder. Purity of the compounds were determined using a reversed-phase HPLC analytical column (C-18, $3.5 \mu \mathrm{m}, 2.1 \times 150 \mathrm{~mm})$ run with $5-95 \%$ acetonitrile in water with $0.1 \%$ TFA over 12 minutes. Exact masses were determined using the Bruker UltrafleXtreme MALDI-TOF. 

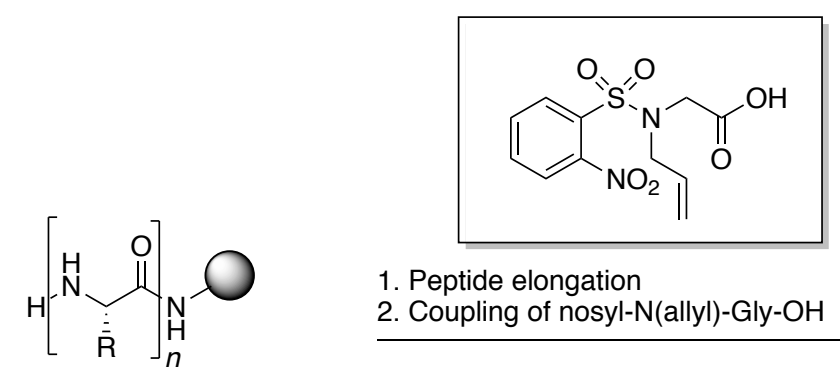

1. Peptide elongation

2. Coupling of nosyl-N(allyl)-Gly-OH

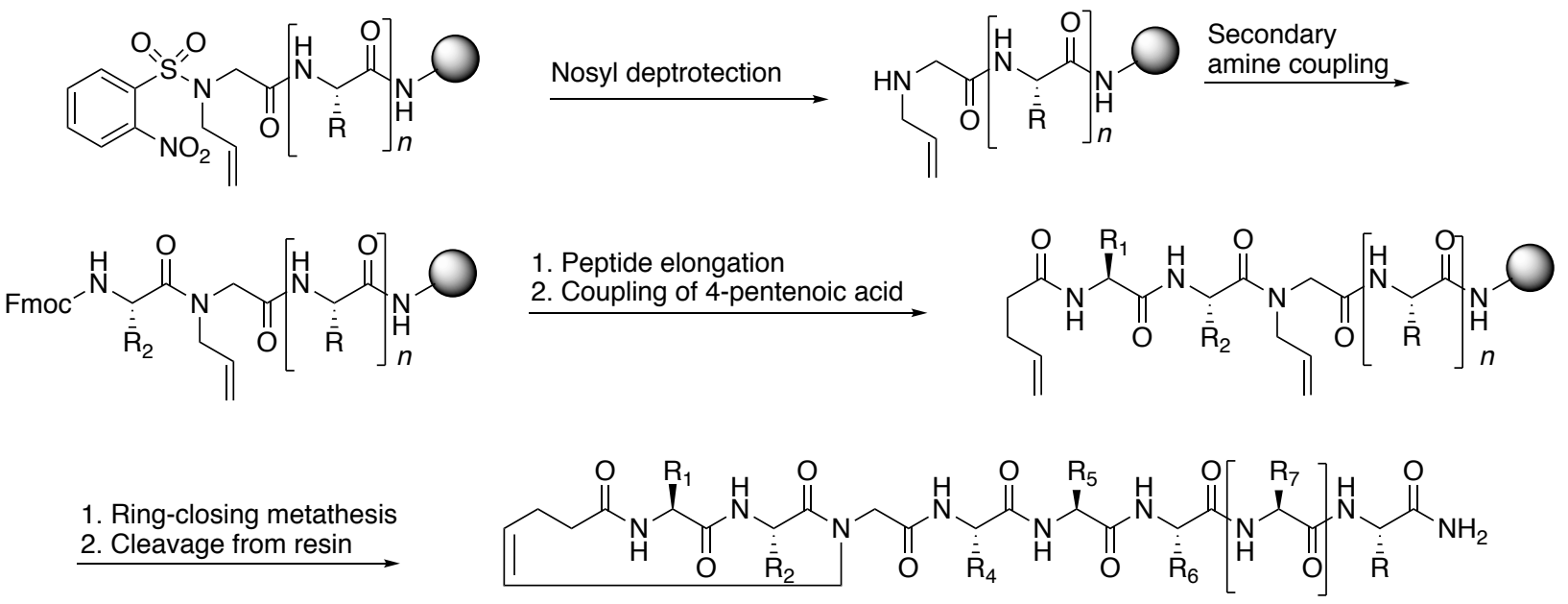

Scheme S1: Solid phase HBS synthesis.

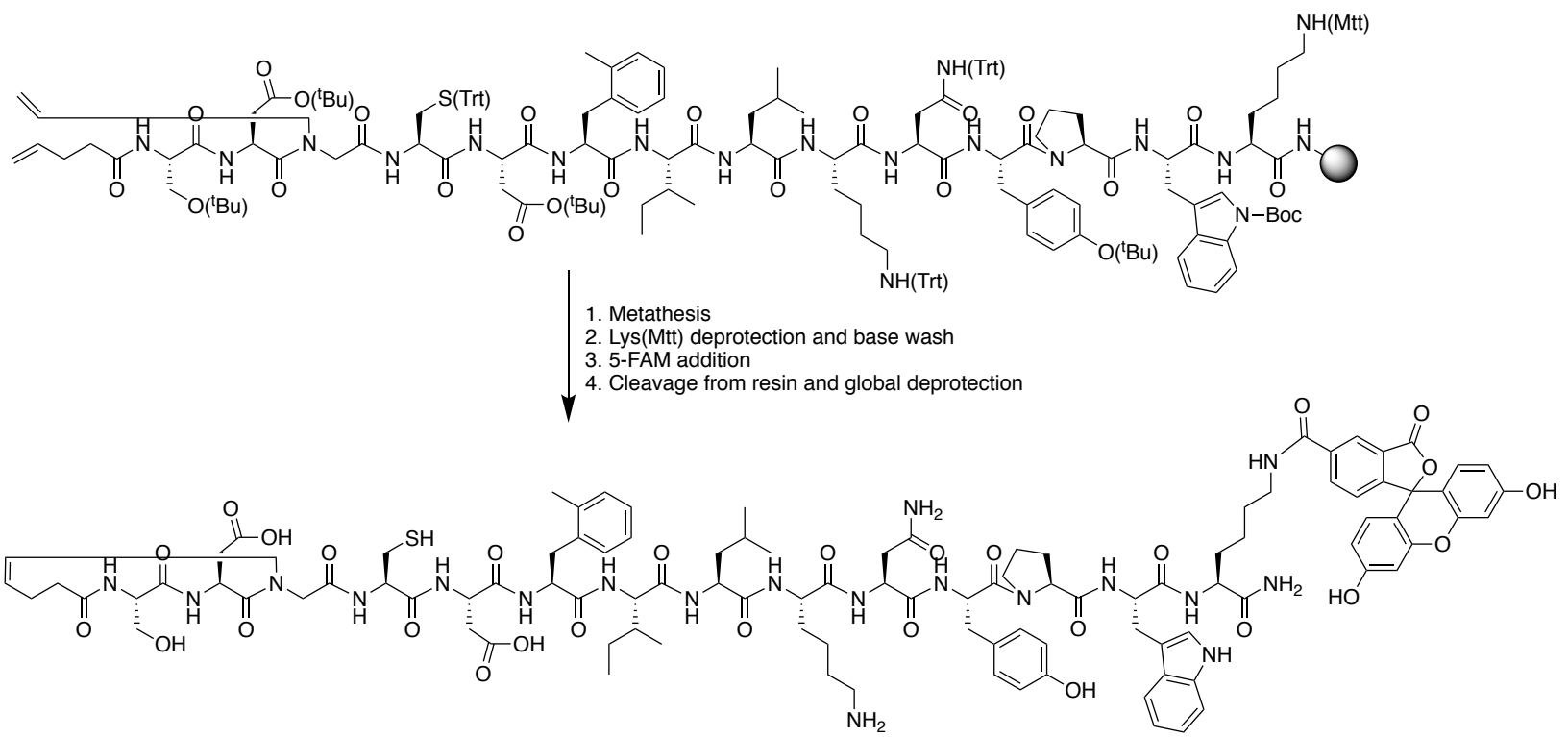

Scheme S2: Solid phase synthesis of screen and hit compounds, example peptide. 


\section{Characterization of purified peptides}

Table S4: Peptide Characterization summary of mass spectrometry results.

\begin{tabular}{|c|c|c|c|}
\hline Compound & Sequence & $\begin{array}{c}{[\mathrm{M}+\mathrm{H}]^{+}} \\
\text {Calc'd }\end{array}$ & $\begin{array}{c}{[\mathrm{M}+\mathrm{H}]^{+}} \\
\text {Obs. }\end{array}$ \\
\hline \multicolumn{4}{|c|}{ HBS Derivatives } \\
\hline HBS I & $\mathrm{XSDG}^{*}(\mathrm{Bcs}) \mathrm{D}(2 \mathrm{meF}) \mathrm{ILKNYPW}-\mathrm{NH}_{2}$ & 1754.817 & 1755.203 \\
\hline \multicolumn{4}{|c|}{ Screening Peptides } \\
\hline HBS I_850_Screen* & XSDG ${ }^{*} \mathrm{CD}(2 \mathrm{meF}) \mathrm{ILKNYPW}(\mathrm{K}-5-\mathrm{FAM})-\mathrm{NH}_{2}$ & 2150.913 & 2151.408 \\
\hline HBS I_857_Screen* & $\mathrm{XSDG}^{*}(\mathrm{Bcs}) \mathrm{D}(2 \mathrm{meF}) \mathrm{ILKNCPW}(\mathrm{K}-5-\mathrm{FAM})-\mathrm{NH}_{2}$ & 2180.906 & 2180.981 \\
\hline HBS I_858_Screen* & $\mathrm{XSDG}^{*}(\mathrm{Bcs}) \mathrm{D}(2 \mathrm{meF}) \mathrm{ILKNYCW}(\mathrm{K}-5-\mathrm{FAM})-\mathrm{NH}_{2}$ & 2246.917 & 2247.198 \\
\hline \multicolumn{4}{|c|}{ Baseline Peptide } \\
\hline HBS I* & XSDG*(Bcs) D(2meF)ILKNYPW(K-5-FAM)-NH ${ }_{2}$ & 2240.960 & 2241.082 \\
\hline \multicolumn{4}{|c|}{ Single Hits } \\
\hline HBS III* & $\mathrm{XSDG}^{*}(\mathrm{CyHex}) \mathrm{D}(2 \mathrm{meF}) \mathrm{ILKNYPW}(\mathrm{K}-5-\mathrm{FAM})-\mathrm{NH}_{2}$ & 2229.051 & 2228.700 \\
\hline HBS IV* & $\mathrm{XSDG}^{*}(\mathrm{Bcs}) \mathrm{D}(2 \mathrm{meF}) \mathrm{ILKN}(\mathrm{CyPent}) \mathrm{PW}(\mathrm{K}-5-\mathrm{FAM})-\mathrm{NH}_{2}$ & 2245.028 & 2244.743 \\
\hline HBS V* & $\mathrm{XSDG}^{*}(\mathrm{Bcs}) \mathrm{D}(2 \mathrm{meF}) \mid \mathrm{LKNY}(\mathrm{C}-\mathrm{IAA}) \mathrm{W}(\mathrm{K}-5-\mathrm{FAM})-\mathrm{NH}_{2}$ & 2304.922 & 2304.770 \\
\hline \multicolumn{4}{|c|}{ Double Hit } \\
\hline HBS VI* & $\mathrm{XSDG}^{*}(\mathrm{CyHex}) \mathrm{D}(2 \mathrm{meF}) \mathrm{ILKNY}(\mathrm{C}-\mathrm{IAA}) \mathrm{W}(\mathrm{K}-5-\mathrm{FAM})-\mathrm{NH}_{2}$ & 2293.013 & 2292.731 \\
\hline \multicolumn{4}{|c|}{ Triple Hit } \\
\hline HBS II* & $\mathrm{XSDG}^{*}(\mathrm{CyHex}) \mathrm{D}(2 \mathrm{meF}) \mathrm{ILKN}(\mathrm{CyPent})(\mathrm{C}-\mathrm{IAA}) \mathrm{W}(\mathrm{K}-5-\mathrm{FAM})-\mathrm{NH}_{2}$ & 2297.080 & 2297.486 \\
\hline HBS II & XSDG* ${ }^{*}$ CyHex)D(2meF)ILKN(CyPent)(C-IAA)W-NH 2 & 1810.938 & 1811.094 \\
\hline
\end{tabular}

All single letter amino acid codes are used above in addition to the following abbreviations: $\mathrm{Ac}=$ Acyl cap; $\mathrm{X}=$ Pentenoic Acid; Bcs = Benzylcysteine; $2 \mathrm{meF}=2$-methyl phenylalanine; CyHex = 5-cyclohexylpentanoic acid from Fmoc-5-cyclohexylpentanoic acid, synthesized; CyPent $=5-$ cyclopentylpentanoic acid from Fmoc-5-cyclohexylpentanoic acid, synthesized; C-IAA = Cys containing iodoacetic acid from Fmoc-Cys(OtBu), synthesized; 5-FAM = 5-carboxyfluoroscien * in compound name denotes the compound has a fluorophore

Figure S6: Analytical traces for peptides in this study (A-K).

A) HBS I

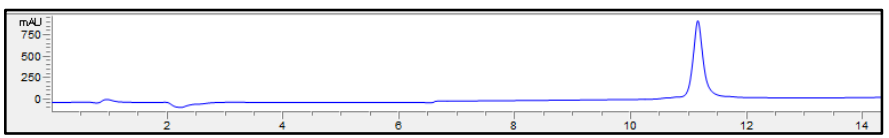

B) HBS I_850_Screen*

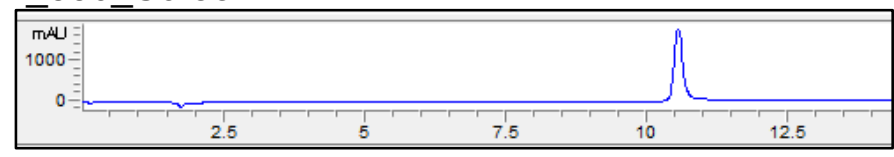

C) HBS I 857 Screen*

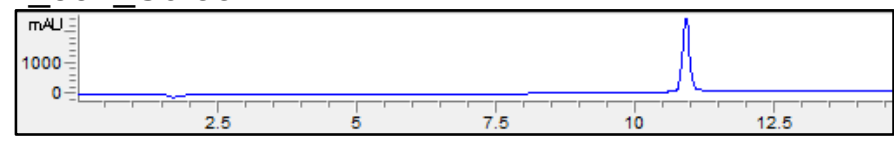


D) HBS I_858_Screen*

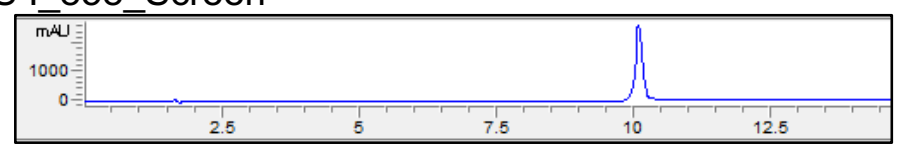

E) HBS I*

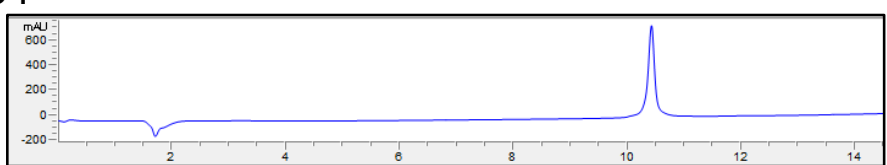

F) HBS III*

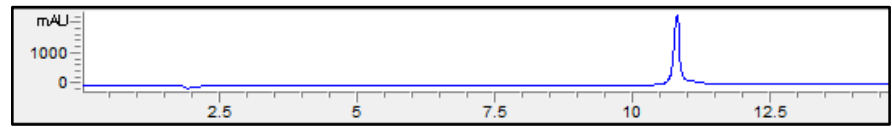

G) HBS IV *

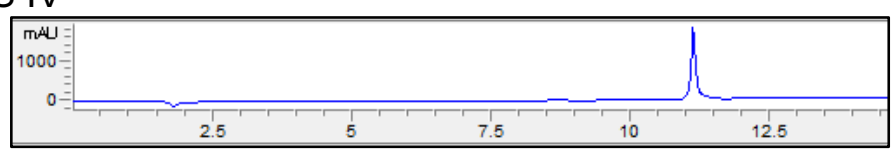

H) HBS V*

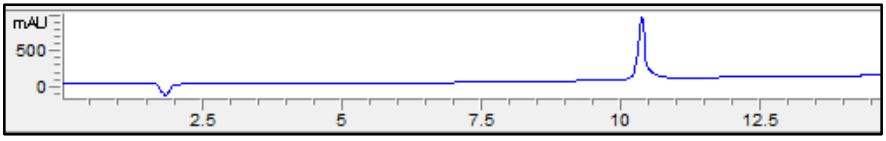

I) HBS VI*

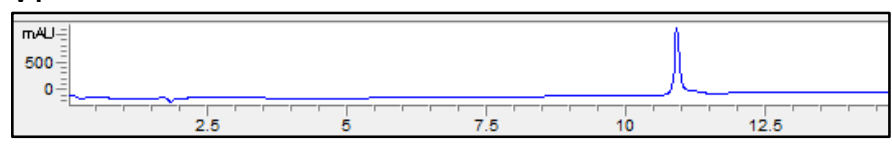

J) HBS $\|^{*}$

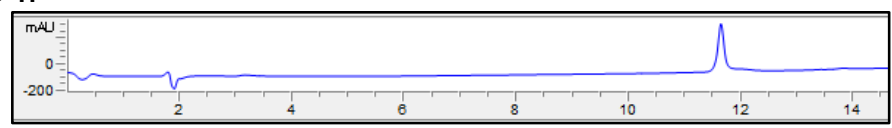

K) HBS II

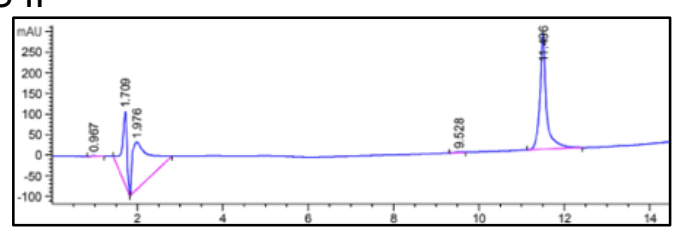




\section{Synthesis Characterization of other peptides used in this study:}

The following peptides can be found in [1]:

MLL ${ }^{847-858:} \quad$ Ac-SDIMDFVLKNTP- $\mathrm{NH}_{2}$

Peptide I: $\quad$ Ac-SDI(Bcs)D(2meF)ILKNYP-OH

Peptide I-NH $\mathrm{N}_{2}$ : Ac-SDI(Bcs)D(2meF)ILKNYP-NH ${ }_{2}$

The following peptide can be found in [2]:

p53 Probe: Ac-EAFSDLWKLLPENNVC ${ }^{\mathrm{Flu}}-\mathrm{NH}_{2}$

Where all single letter amino acid codes are used above in addition to the following abbreviations:

$$
\begin{aligned}
& \text { Ac = Acyl cap } \\
& \text { Bcs = Benzylcysteine } \\
& \text { 2meF = 2-methyl phenylalanine } \\
& \text { Flu = 5-acetamidofluorescein. }
\end{aligned}
$$

\section{E. Circular Dichroism Studies}

Spectra were recorded using AVIV 202SF CD spectrometer or JASCO CS spectrometer in $1 \mathrm{~mm}$ cells at $25.00{ }^{\circ} \mathrm{C}, 1.000 \mathrm{~nm}$ bandwidth slits, from $260.00 \mathrm{~nm}$ to $185.00 \mathrm{~nm}$ with increments of $0.500 \mathrm{~nm}$, averaging time of 0.500 seconds, with 4 scans per sample. Baselines were subtracted from analogous conditions as that from samples. Each sample was prepared at $50 \mu \mathrm{M}$ in $0.1 \mathrm{X}$ PBS (13.7 mM NaCl, $0.27 \mathrm{mM} \mathrm{KCl}, 1 \mathrm{mM} \mathrm{Na}_{2} \mathrm{HPO}_{4}, 0.18 \mathrm{mM} \mathrm{KH}_{2} \mathrm{PO}_{4}, \mathrm{pH} 7.4$ ) as performed in Joy, S. T., et al. and Rooklin, D., et al [1, 3].

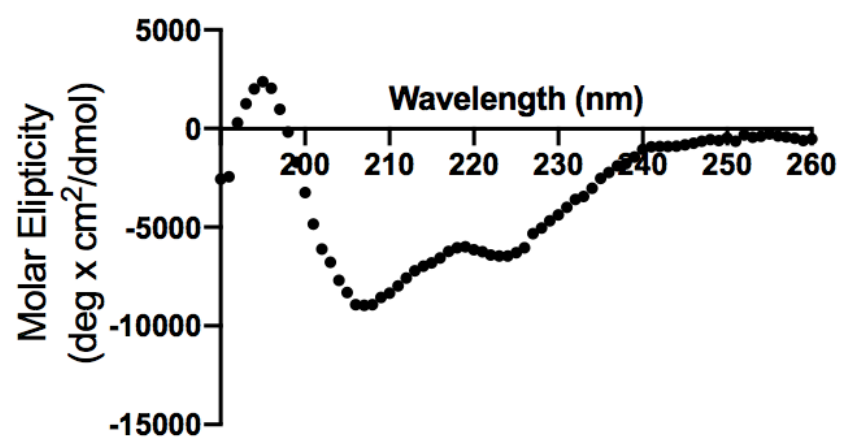

Figure S7: Representative CD data. CD for HBS II.

\section{F. Protein Expression and Purification}

His-KIX expression and purification: was carried out in the same manner as it was in [1].

MDM2 expression and purification: was carried out as performed in [6], with supplementing lysis buffers with DNAse and adjusting the $\mathrm{NaCl}$ concentration to $1 \mathrm{M}$ throughout.

\footnotetext{
${ }^{15} \mathrm{~N}$ Labeled His-KIX expression and purification: All media was supplemented with Ampicillin (100 $\mathrm{mg} / \mathrm{mL}$ in water) and Chlroamphenicol (25 mg/mL in ethanol). LB was inoculated for an overnight growth and grown at $37^{\circ} \mathrm{C}$. Cells were pelleted and the supernatant was discarded. Cells were then added to and grown in $\mathrm{M} 9$ media (M9 salts, ${ }^{15} \mathrm{~N}-\mathrm{NH}_{4} \mathrm{Cl}, \mathrm{MgSO}_{4}, \mathrm{CaCl}_{2}, \mathrm{Glucose}$, and $2.5 \mathrm{~mL}$
} 
of 10X Bioexpress Media from Cambridge Isotopes). At OD $600=0.6$, the temperature was lowered to $25^{\circ} \mathrm{C}$, and the culture was induced with $0.1 \mathrm{mM}$ IPTG. The cells were grown for 12 hours at $25^{\circ} \mathrm{C}$ before harvesting and storing them at $-80{ }^{\circ} \mathrm{C}$ with $10 \%$ glycerol. Purification was performed in the same manner for KIX in [1].

\section{G. Fluorescence Polarization Methods Sample Preparation:}

Concentrations of protein and peptide samples were determined using Nanodrop 2000c (ThermoScientific).

\section{Direct Binding Experiments:}

Experiments were performed in triplicate in a 96-well plate format. His-KIX or MDM2 was concentrated in $10 \%$ glycerol in PBS $\left(137 \mathrm{mM} \mathrm{NaCl}, 2.7 \mathrm{mM} \mathrm{KCl}, 10 \mathrm{mM} \mathrm{Na} 2 \mathrm{HPO}_{4}, 1.8 \mathrm{mM}\right.$ $\mathrm{KH}_{2} \mathrm{PO}_{4}, \mathrm{pH} 7.4$ ) using Amicon Ultra Centrifugal filters according to the manufacturer's protocol. Pluronic F-127 (Sigma) was added to a final concentration of $0.1 \%$ in each experiment. All fluorescently-tagged peptides were dissolved in the same buffer as the protein and were at a final concentration of $15 \mathrm{nM}$. Each plate incubated for 60 minutes at room temperature and was read on a DTX 880 Multimode Detector (Beckman) at $25^{\circ} \mathrm{C}$ with excitation of $485 \mathrm{~nm}$ and emission of $525 \mathrm{~nm}$. Raw values were fit to a Sigmoidal, 4PL, model where $X$ is log(concentration) in GraphPad Prism 8.0. to obtain the $\mathrm{EC}_{50}$ value. The binding affinities $\left(K_{\mathrm{d}}\right)$ for each peptide was determined using the following equation as performed in Lao, et al. [7] The following equation from [8] was used:

$$
K_{\mathrm{d}}=\left(\mathrm{R}_{\mathrm{T}} \times\left(1-\mathrm{F}_{\mathrm{SB}}\right)+\mathrm{L}_{\mathrm{ST}} \times \mathrm{F}_{\mathrm{SB}}{ }^{2}\right) / \mathrm{F}_{\mathrm{SB}}-\mathrm{L}_{\mathrm{ST}}
$$

$\mathrm{R}_{\mathrm{T}}=\mathrm{EC}_{50}$ value determined by prism

$\mathrm{F}_{\mathrm{SB}}=$ fraction bound $=0.5$ (in the case of $\mathrm{EC}_{50}$ )

$\mathrm{L}_{\mathrm{ST}}=$ total concentration of Flu-peptide $=15 \mathrm{nM}$ (for all experiments)

\section{Competition Binding Experiments:}

Inhibition studies were performed using WT-MLL Flu, His-KIX and unlabeled peptides. The WTMLL Flu $^{\text {used in these studies is the same used in [1] with FITC- } \beta A l a-D C G N I L P S D I M D F V L K N T P-~}$ $\mathrm{NH}_{2}$. All studies were performed in triplicate in a 96 well plate format and contained final concentrations of $10 \%$ glycerol and $0.1 \%$ Pluronic F-127 (Sigma) in PBS, pH 7.4. The MLL analogues were dissolved in DMSO and added so that the final concentration of DMSO in the well was $5 \%$. As performed in direct binding studies, the WT-MLL Flu was at a final concentration of 15 $\mathrm{nM}$. A blank direct binding study was performed with WT-MLL Flu and DMSO with no compound present to determine the concentration of His-KIX at $70 \%$ saturation unless except for HBS-FT and HBS-W, which were tested at $65 \%$ saturation. In each well were varying amounts of MLL analogues in DMSO. Samples were incubated at room temperature for 60 minutes before reading the plate. The detection was read with the same parameters as done in the direct binding studies. The competition binding affinities $\left(K_{\mathrm{l}}\right)$ for each peptide was determined using the following equation as performed in Lao, et al. [7] For compounds that did not fully compete out the probe, the $K_{i}$ was estimated by plugging in the $Y=50 \%$ saturation into the $K_{d}$ calculator. $95 \%$ confidence intervals were determined by taking the difference between the lower confidence interval and value determined by Prism. The following equation from [8] was used:

$$
\left.K_{\mathrm{i}}=K_{d}{ }^{*} \mathrm{~F}_{\mathrm{SB}}{ }^{*}\left(\left(\mathrm{~L}_{\mathrm{T}} / \mathrm{L}_{\mathrm{ST}}{ }^{*} \mathrm{~F}_{\mathrm{SB}}-\left(K_{\mathrm{d}}+\mathrm{L}_{\mathrm{ST}}+\mathrm{R}_{\mathrm{T}}\right)^{*} \mathrm{~F}_{\mathrm{SB}}+\mathrm{R}_{\mathrm{T}}\right)\right)-1 /\left(1-\mathrm{F}_{\mathrm{SB}}\right)\right)
$$

$K_{d}=K_{d}$ of WT-MLL Flu to His-KIX from equation Direct Binding (1) 
$\mathrm{F}_{\mathrm{SB}}=$ Fraction of WT-MLL Flu bound to His-KIX at $\mathrm{EC}_{50}$

$\mathrm{L}_{T}=$ Total concentration of WT-MLL Flu

$\mathrm{L}_{S T}=\mathrm{EC}_{50}$ of peptide from competition curve using equation (1) as determined by Prism

$\mathrm{R}_{\mathrm{T}}=$ Total concentration of His-KIX protein

\section{H. Protein NMR Titration Studies}

The ${ }^{1} \mathrm{H}-{ }^{15} \mathrm{~N}-\mathrm{HSQC}$ experiments were carried out using a $600 \mathrm{MHz}$ Bruker 4-channel NMR spectrometer equipped with a $5 \mathrm{~mm} \mathrm{TCl}$ cryogenic probe. Experiments were performed at $27^{\circ} \mathrm{C}$ using a standard pulse sequence and analyzed by Topspin 4.0.6 (Bruker) and MestReNova 6.0.2. Uniformly ${ }^{15} \mathrm{~N}$-labelled $\mathrm{KIX}$ was buffer exchanged into NMR buffer $\left(9: 1 \mathrm{H}_{2} \mathrm{O}: \mathrm{D}_{2} \mathrm{O}, 10 \mathrm{mM}\right.$ phosphate buffer containing $100 \mathrm{mM} \mathrm{NaCl}$ at $\mathrm{pH}$ 7.2) using Amicon Ultra centrifugal filter (Millipore). ${ }^{1} \mathrm{H}-{ }^{15} \mathrm{~N}-\mathrm{HSQC}$ NMR of ${ }^{15} \mathrm{~N}$-labeled $\mathrm{KIX}(100 \mu \mathrm{M})$ was collected, and peaks were assigned based on published data [9,10]. For peptide titration experiments, 0.5 and 1 molar equivalents of HBS II dissolved in NMR buffer were added to the protein solution. The change in chemical shift after the addition of peptide was plotted for each KIX residue. Chemical shift changes ${ }^{1} \mathrm{H}$ and ${ }^{15} \mathrm{~N}$ were averaged by using the formula:

$$
\text { Shift }=\sqrt{0.5 \times\left[\delta_{\mathrm{H}}^{2}+\left(\alpha \times \delta_{\mathrm{N}}^{2}\right)\right]}
$$

with the scale factor $\alpha$ taken to be 0.14 [11]. 


\section{Synthesis, Purification, and Characterization of Small Molecules General synthesis for disulfides:}

Disulfide precursors were synthesized similar to those activated disulfides in [12]. 465 mgs (1.5 mmoles, 1 eq.) of 2,2'-Dithiobis(5-nitropyridine) aka DTNP were dissolved in $15 \mathrm{mLs}$ of TFA/DCM $50 / 50$. The respective thiols ( 1.8 mmoles, 1.2 eq.) were added directly to the solution and stirred for two hours at room temperature. TLC confirmed disappearance of the DTNP starting material and the product was concentrated in vacuo. The products were used as crude alkylators in the screening studies. DS-2 was also synthesized and purified and used in a crude versus purified disulfide alkylator study.

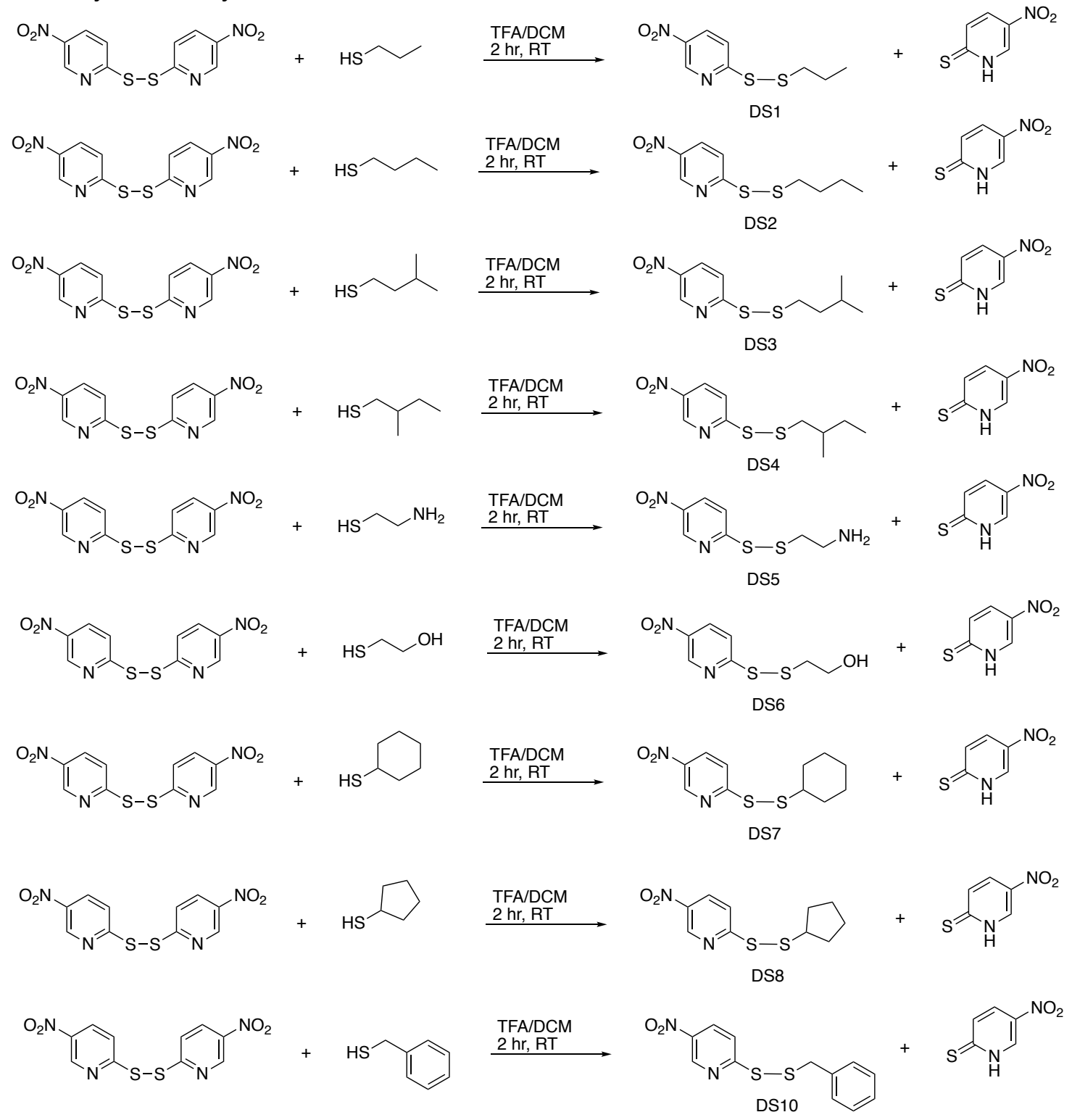

Scheme S3: Asymmetric disulfide synthesis. 
DS1: DS1 was synthesized according to the general procedure for disulfides using 465 mgs (1.5 mmoles, 1 eq.) of 2,2'-Dithiobis(5-nitropyridine) (1.8 mmoles, 1.2 eq.) and $163 \mu \mathrm{Ls}$ (1.8 mmoles, 1.2 eq.) of propylmercaptan. The product was not isolated.

DS2 Crude: DS2 Crude was synthesized according to the general procedure for disulfides using 465 mgs (1.5 mmoles, 1 eq.) of 2,2'-Dithiobis(5-nitropyridine) (1.8 mmoles, 1.2 eq.) and $193 \mu \mathrm{Ls}$ (1.8 mmoles, 1.2 eq.) of n-butylmeraptan. The product was not isolated.

DS3: DS3 was synthesized according to the general procedure for disulfides using 465 mgs (1.5 mmoles, 1 eq.) of 2,2'-Dithiobis(5-nitropyridine) (1.8 mmoles, 1.2 eq.) and $225 \mu \mathrm{Ls}$ (1.8 mmoles, 1.2 eq.) of 3-methyl-1-butanethiol. The product was not isolated.

DS4: DS4 was synthesized according to the general procedure for disulfides using 465 mgs (1.5 mmoles, 1 eq.) of 2,2'-Dithiobis(5-nitropyridine) (1.8 mmoles, 1.2 eq.) and $221 \mu \mathrm{Ls}$ (1.8 mmoles, 1.2 eq.) of 2-methylbutane-1-thiol. The product was not isolated.

DS5: DS5 was synthesized according to the general procedure for disulfides using 465 mgs (1.5 mmoles, 1 eq.) of 2,2'-Dithiobis(5-nitropyridine) (1.8 mmoles, 1.2 eq.) and 203 mgs (1.8 mmoles, 1.2 eq.) of cysteamine- $\mathrm{HCl}$. The product was not isolated.

DS6: DS6 was synthesized according to the general procedure for disulfides using 465 mgs (1.5 mmoles, 1 eq.) of 2,2'-Dithiobis(5-nitropyridine) (1.8 mmoles, 1.2 eq.) and $127 \mu \mathrm{Ls}$ (1.8 mmoles, 1.2 eq.) of mercaptoethanol. The product was not isolated.

DS7: DS7 was synthesized according to the general procedure for disulfides using 465 mgs (1.5 mmoles, 1 eq.) of 2,2'-Dithiobis(5-nitropyridine) (1.8 mmoles, 1.2 eq.) and $220 \mu \mathrm{Ls}$ (1.8 mmoles, 1.2 eq.) of cyclohexanethiol. The product was not isolated.

DS8: DS8 was synthesized according to the general procedure for disulfides using 465 mgs (1.5 mmoles, 1 eq.) of 2,2'-Dithiobis(5-nitropyridine) (1.8 mmoles, 1.2 eq.) and $193 \mu \mathrm{Ls}$ (1.8 mmoles, 1.2 eq.) of cyclopentanethiol. The product was not isolated.

DS10: DS10 was synthesized according to the general procedure for disulfides using $465 \mathrm{mgs}$ (1.5 mmoles, 1 eq.) of 2,2'-Dithiobis(5-nitropyridine) (1.8 mmoles, 1.2 eq.) and $184 \mu \mathrm{Ls}$ (1.8 mmoles, 1.2 eq.) of benzylmercaptan. The product was not isolated.

DS2 Pure: See Scheme S3 for scheme.

In addition to the crude variant, DS2 Pure was synthesized according to the general procedure for disulfides using $465 \mathrm{mgs}$ (1.5 mmoles, 1 eq.) of 2,2'-Dithiobis(5-nitropyridine) (1.8 mmoles, 1.2 eq.) and $193 \mu \mathrm{Ls}$ (1.8 mmoles, 1.2 eq.) of $n$-butylmercaptan The product was purified on a Biotage Isolera One silica column using a 1-7\% gradient of ethyl acetate in hexanes. The product was obtained as an off white solid ( $205 \mathrm{mgs}, 56 \%$ yield).

$\mathrm{R}_{f}=0.41$ in $5 \%$ EtOAc/hexane

HRMS (APCI): Calculated [M+H] $]^{+}$245.0340, Observed [M+H] ${ }^{+} 245.0615$.

${ }^{1} \mathrm{H}$ NMR $\left(500 \mathrm{MHz}, \mathrm{CDCl}_{3}\right) \delta 9.21(\mathrm{~d}, J=2.5 \mathrm{~Hz}, 1 \mathrm{H}), 8.38(\mathrm{dd}, J=8.9,2.6 \mathrm{~Hz}, 1 \mathrm{H}), 7.90(\mathrm{~d}, J=$ $8.9 \mathrm{~Hz}, 1 \mathrm{H}), 2.83-2.78(\mathrm{~m}, 2 \mathrm{H}), 1.69-1.61(\mathrm{~m}, 2 \mathrm{H}), 1.45-1.35(\mathrm{~m}, 2 \mathrm{H}), 0.88(\mathrm{t}, \mathrm{J}=7.4 \mathrm{~Hz}$, $3 \mathrm{H})$

${ }^{13} \mathrm{C} \mathrm{NMR}\left(126 \mathrm{MHz}, \mathrm{CDCl}_{3}\right) \delta 169.39,145.06,141.92,131.60,119.09,77.42,77.16,76.91,38.74$, $31.04,21.64,13.62$. 
Preparation of (1A) Fmoc-5-cyclohexylpent-4-enoic acid:<smiles>C=CCC(NC=C)C(=O)O</smiles>

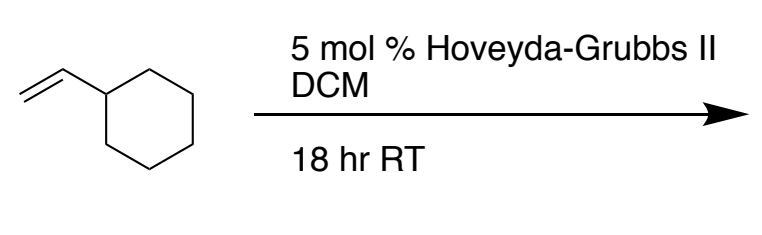

Scheme S4: Preparation of $1 \mathrm{~A}$.<smiles>O=C(O)[C@H](C/C=C/C1CCCCC1)NC(F)F</smiles>

$1 \mathrm{~A}$

$750 \mathrm{mgs}$ (2.22 mmol, 1 eq.) of Fmoc-allyl-L-glycine-OH and $70 \mathrm{mgs}(0.11 \mathrm{mmol}, 0.05$ eq.) of Hoveyda-Grubbs second generation catalyst were dissolved in $10 \mathrm{mLs}$ of anhydrous, degassed dichloromethane. $1.52 \mathrm{mLs}(11.11 \mathrm{mmol}, 5 \mathrm{eq}$.) of vinylcyclohexne were added and the reaction was stirred overnight at room temperature. The product was purified by column chromatography using a Biotage Isolera One using a 5-45\% ethyl acetate in hexanes gradient supplemented with $0.2 \%$ formic acid. $1 \mathrm{~A}$ was obtained as an off-white solid (376 $\mathrm{mgs}, 40 \%$ yield).

$\mathrm{R}_{f}=0.58$ in $35 \%$ EtOAc/hexane $+0.2 \%$ formic acid HRMS (APCl): Calculated [M+H] $]^{+} 420.2097$, Observed [M+H] 420.2178

${ }^{1} \mathrm{H} \mathrm{NMR}\left(500 \mathrm{MHz}, \mathrm{CDCl}_{3}\right) \delta 7.77(\mathrm{~d}, J=7.5 \mathrm{~Hz}, 2 \mathrm{H}), 7.59(\mathrm{~m}, J=7.0 \mathrm{~Hz}, 2 \mathrm{H}), 7.40(\mathrm{t}, J=7.4$ $\mathrm{Hz}, 2 \mathrm{H}), 7.31(\mathrm{~m}, \mathrm{~J}=7.4,0.8 \mathrm{~Hz}, 2 \mathrm{H}), 5.58-5.44(\mathrm{~m}, 1 \mathrm{H}), 5.33-5.19(\mathrm{~m}, 2 \mathrm{H}), 4.49-4.335(\mathrm{~m}$, $3 \mathrm{H}), 4.24(\mathrm{t}, J=6.6 \mathrm{~Hz}, 1 \mathrm{H}), 2.52(\mathrm{~m}, J=27.4,13.7,6.9 \mathrm{~Hz}, 2 \mathrm{H}), 1.94(\mathrm{~m}, J=3.8 \mathrm{~Hz}, 1 \mathrm{H}), 1.75$ -1.52 (overlapping, $5 \mathrm{H}$ ), $1.32-0.98$ (overlapping, $5 \mathrm{H}$ )

${ }^{13} \mathrm{C}$ NMR $\left(126 \mathrm{MHz}, \mathrm{CDCl}_{3}\right) \delta 176.40,156.02,143.83,142.56,141.46,127.89,127.21,125.25$, $120.37,120.15,77.16,67.32,53.43,47.27,40.85,35.33,33.05,26.23,26.08$.

\section{Preparation of (1B) Fmoc-5-cyclohexylpentanoic acid:}<smiles>O=C(O)[C@H](C/C=C/C1CCCCC1)NC(F)F</smiles>

$1 \mathrm{~A}$

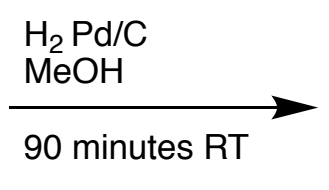

Scheme S5: Preparation of 1B.<smiles>O=C(O)[C@H](CCCC1CCCCC1)NC(F)F</smiles>

1B

$376 \mathrm{mgs}$ ( 0.90 mmoles, 1 eq.) of $1 \mathrm{~A}$ was dissolved in $90 \mathrm{mLs}$ of $\mathrm{MeOH}$. The reaction vessel was flushed with nitrogen and $9.5 \mathrm{mgs}$ of $\mathrm{Pd} / \mathrm{C}(0.09 \mathrm{mmoles}, 0.10 \mathrm{~mol} \%, 0.1 \mathrm{eq}$.) was added to the solution. The reaction vessel was then flushed with hydrogen $(\mathrm{g})$ and the reaction was allowed to proceed for 90 minutes. Upon completion, the reaction was filtered over Celite ${ }^{\circledR}$ and dried in vacuo to yield an off white solid (421 $\mathrm{mgs}, 85 \%$ yield).

$\mathrm{R}_{f}=0.62$ in $35 \%$ EtOAc/hexane $+0.2 \%$ formic acid HRMS (APCI): Calculated [M+H] $]^{+} 422.2253$, Observed $[\mathrm{M}+\mathrm{H}]^{+} 422.2369$ 
${ }^{1} \mathrm{H}$ NMR $\left(500 \mathrm{MHz}, \mathrm{CDCl}_{3}\right) \delta 7.76(\mathrm{~d}, J=7.2 \mathrm{~Hz}, 2 \mathrm{H}), 7.59(\mathrm{~m}, 2 \mathrm{H}), 7.39(\mathrm{~m}, J=7.2 \mathrm{~Hz}, 2 \mathrm{H}), 7.34$ $-7.28(\mathrm{~m}, 2 \mathrm{H}), 5.24(\mathrm{~d}, J=6.9 \mathrm{~Hz}, 1 \mathrm{H}), 4.42(\mathrm{~d}, J=6.4 \mathrm{~Hz}, 2 \mathrm{H}), 4.23(\mathrm{~s}, 1 \mathrm{H}), 1.88(\mathrm{~s}, 1 \mathrm{H}), 1.64$ $(\mathrm{m}, J=33.8,12.9 \mathrm{~Hz}, 5 \mathrm{H}), 1.53(\mathrm{dd}, J=7.5,2.0 \mathrm{~Hz}, 1 \mathrm{H}), 1.48(\mathrm{~s}, 1 \mathrm{H}), 1.39(\mathrm{~s}, 2 \mathrm{H}), 1.27-1.08$ $(\mathrm{m}, 5 \mathrm{H}), 0.86(\mathrm{~d}, J=9.6 \mathrm{~Hz}, 2 \mathrm{H})$.

${ }^{13} \mathrm{C}$ NMR $\left(126 \mathrm{MHz}, \mathrm{CDCl}_{3}\right) \delta$ 141.47, 127.89, 127.23, 125.20, 47.29, 37.55, 33.48, 26.78, 26.48.

Preparation of fmoc-5-cyclopentylpent-4-enoic acid (2A):<smiles>C=CC[C@H](NC(F)F)C(=O)O</smiles><smiles>C=CC1CCCC1</smiles>
$5 \mathrm{~mol} \%$ Hoveyda-Grubbs II

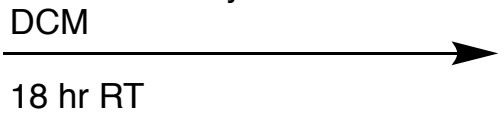<smiles>O=C(O)[C@H](C/C=C/C1CCCC1)NC(F)F</smiles>

$2 \mathrm{~A}$

Scheme S6: Preparation of 2A.

$750 \mathrm{mgs}$ (2.22 mmol, 1 eq.) of Fmoc-allyl-L-glycine-OH and $70 \mathrm{mgs}(0.11 \mathrm{mmol}, 0.05$ eq.) of Hoveyda-Grubbs second generation catalyst were dissolved in $10 \mathrm{mLs}$ of anhydrous, degassed dichloromethane. $1.52 \mathrm{mLs}(11.11 \mathrm{mmol}, 5 \mathrm{eq}$.) of vinylcyclopentane were added and the reaction was stirred overnight at room temperature. The product was purified by column chromatography using a $5-45 \%$ ethyl acetate in hexanes gradient supplemented with $0.2 \%$ formic acid. $2 \mathrm{~A}$ was obtained as an off-white solid (254 mgs, $28 \%$ yield).

$\mathrm{R}_{f}=0.57$ in $35 \%$ EtOAc/hexane $+0.2 \%$ formic acid HRMS (APCI): Calculated $[\mathrm{M}+\mathrm{H}]^{+}$406.1940, Observed [M+H] 406.2040 ${ }^{1} \mathrm{H}$ NMR $\left(500 \mathrm{MHz}_{\mathrm{CDCl}}\right) \delta 7.77(\mathrm{~d}, J=7.5 \mathrm{~Hz}, 2 \mathrm{H}), 7.59(\mathrm{~m}, J=7.1 \mathrm{~Hz}, 2 \mathrm{H}), 7.40(\mathrm{t}, J=7.4$ $\mathrm{Hz}, 2 \mathrm{H}), 7.31(\mathrm{t}, J=7.4 \mathrm{~Hz}, 2 \mathrm{H}), 5.56(\mathrm{dt}, J=17.5,8.8 \mathrm{~Hz}, 1 \mathrm{H}), 5.29(\mathrm{~m}, J=28.7,14.3,7.5 \mathrm{~Hz}$, $2 \mathrm{H}), 4.53-4.33(\mathrm{~m}, 2 \mathrm{H}), 4.23(\mathrm{~m}, \mathrm{~J}=8.9,4.9 \mathrm{~Hz}, 1 \mathrm{H}), 2.77-2.46(\mathrm{~m}, 2 \mathrm{H}), 2.42(\mathrm{dd}, J=16.0$, $8.0 \mathrm{~Hz}, 1 \mathrm{H}), 1.82-1.63(\mathrm{~m}, 2 \mathrm{H}), 1.55(\mathrm{dd}, J=7.2,4.1 \mathrm{~Hz}, 4 \mathrm{H}), 1.31-1.18(\mathrm{~m}, 2 \mathrm{H})$.

${ }^{13} \mathrm{C}$ NMR $\left(126 \mathrm{MHz}, \mathrm{CDCl}_{3}\right) \delta 176.66,156.03,143.83,141.46,141.24,127.89,127.21,125.21$, $120.91,120.15,77.16,67.33,53.47,47.27,43.32,38.24,35.27,33.22,25.58,25.24$.

\section{Preparation of fmoc-5-cyclopentylpentanoic acid (2B):}<smiles>O=C(O)C(C/C=C/C1CCCC1)NC(F)F</smiles>

$2 \mathrm{~A}$

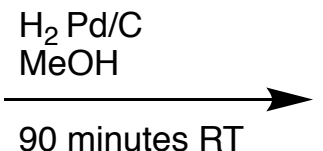

90 minutes $\mathrm{RT}$<smiles>O=C(O)[C@H](CCCC1CCCC1)NC(F)F</smiles>

2B

Scheme S7: Preparation of 2B.

$254 \mathrm{mgs}(0.63 \mathrm{mmol}, 1$ eq. ) of $2 \mathrm{~A}$ was dissolved in $66 \mathrm{mLs}$ of $\mathrm{MeOH}$. The reaction vessel was flushed with nitrogen and $6.6 \mathrm{mgs}$ of $\mathrm{Pd} / \mathrm{C}(10 \mathrm{~mol} \%)$ were added to the solution. The reaction vessel was then flushed with hydrogen $(\mathrm{g})$ and the reaction was allowed to proceed for 90 
minutes. Upon completion, the reaction was filtered over Celite ${ }^{\circledR}$ and dried in vacuo to yield an off white solid (195 mgs, 76\% yield).

$\mathrm{R}_{f}=0.62$ in $35 \%$ EtOAc/hexane $+0.2 \%$ formic acid

HRMS (APCI): Calculated [M+H] 408.2098 , Observed [M+H] 408.2207

${ }^{1} \mathrm{H}$ NMR $\left(500 \mathrm{MHz}, \mathrm{CDCl}_{3}\right) \delta 7.76(\mathrm{~d}, J=7.2 \mathrm{~Hz}, 3 \mathrm{H}), 7.58(\mathrm{~m}, J=16.7,10.8 \mathrm{~Hz}, 2 \mathrm{H}), 7.38(\mathrm{~m}, J$ $=14.7,7.1 \mathrm{~Hz}, 2 \mathrm{H}), 7.32(\mathrm{~m}, J=12.3,3.7 \mathrm{~Hz}, 2 \mathrm{H}), 5.35-5.20(\mathrm{~m}, 1 \mathrm{H}), 4.56-4.35(\mathrm{~m}, 2 \mathrm{H}), 4.23$ $(\mathrm{t}, J=6.7 \mathrm{~Hz}, 1 \mathrm{H}), 1.88(\mathrm{~s}, 1 \mathrm{H}), 1.73(\mathrm{~s}, 4 \mathrm{H}), 1.59(\mathrm{~s}, 2 \mathrm{H}), 1.55-1.45(\mathrm{~m}, 2 \mathrm{H}), 1.43-1.22(\mathrm{~m}$, $4 \mathrm{H}), 1.06(\mathrm{~s}, 2 \mathrm{H})$.

${ }^{13} \mathrm{C}$ NMR $\left(126 \mathrm{MHz}, \mathrm{CDCl}_{3}\right) \delta 149.13,141.46,127.88,127.22,127.07,127.05,124.15,120.15$, 119.98, 77.16, 67.27, 47.29, 42.57, 39.99, 35.72, 32.81, 32.75, 25.28, 24.56, 18.32.

\section{Preparation of (3) Fmoc-Cys(OtBu)-OH:}<smiles>O=C(O)C(CS[Tl])NC(F)F</smiles>

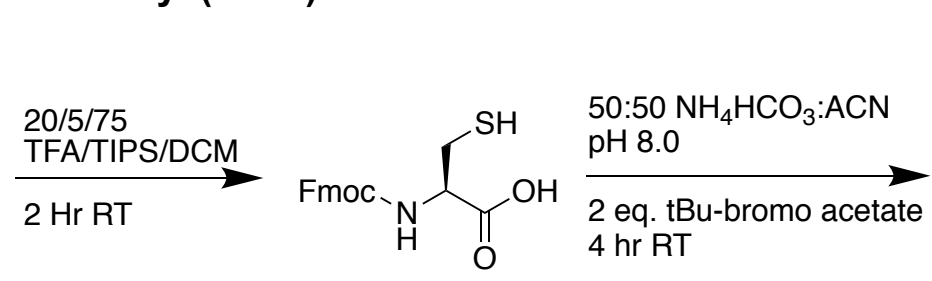

Scheme S8: Preparation of 3.

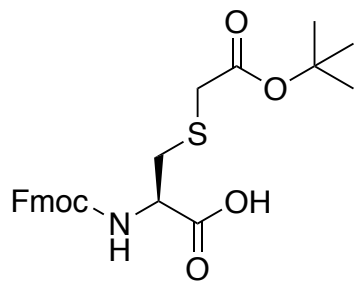

3

$3 \mathrm{~g}$ (5.12 mmol, 1 eq.) of Fmoc-Cys(Trt)-OH was dissolved in $75 \mathrm{mLs}$ of DCM. $20 \mathrm{mLs}$ of TFA and $5 \mathrm{mLs}$ of triisopropylsilane (TIPS) were added and stirred at room temperature for 2 hours. The solution was concentrated in vacuo and rinsed with DCM to remove excess TFA. Fmoc-Cys$\mathrm{OH}$ was then dissolved in $250 \mathrm{mLs}$ of $100 \mathrm{mM}$ ammonium bicarbonate and $250 \mathrm{~mL}$ acetonitrile. The $\mathrm{pH}$ was adjusted to $\mathrm{pH} 8.0$ using solid ammonium bicarbonate. $1.35 \mathrm{mLs}$ (10.24 mmol, 2 eq.) of tert-butyl bromoacetate were added directly to the solution and the solution was stirred for 4 hours at room temperature. Upon completion, the $\mathrm{pH}$ was adjusted to 7 using $5 \%$ citric acid aqueous solution. The acetonitrile was removed in vacuo and compound 3 was extracted using ethyl acetate (2X). The organic layer was subsequently washed with water (3X) and brine (1X) before drying over magnesium sulfate and concentrating in vacuo. Compound 3 was purified using a $10-50 \%$ gradient of ethyl acetate in hexane supplemented with $0.2 \%$ formic acid (543 mgs, $23 \%$ yield over two steps). The proton NMR is in agreement with established literature results of compound 3 [13].

$\mathrm{R}_{f}=0.43$ in $35 \%$ EtOAc/hexane $+0.2 \%$ formic acid HRMS (APCI): Calculated [M+H] ${ }^{+} 458.1559$, Observed [M+H] 458.1663

${ }^{1} \mathrm{H}$ NMR $\left(500 \mathrm{MHz}, \mathrm{CDCl}_{3}\right) \delta 9.21(\mathrm{~s}, 1 \mathrm{H}), 7.76(\mathrm{~d}, J=7.5 \mathrm{~Hz}, 2 \mathrm{H}), 7.61(\mathrm{~m}, J=29.8,14.9 \mathrm{~Hz}$, 2H), $7.44-7.35(\mathrm{~m}, 2 \mathrm{H}), 7.32(\mathrm{~m}, J=7.5,1.0 \mathrm{~Hz}, 2 \mathrm{H}), 6.17(\mathrm{~d}, J=7.9 \mathrm{~Hz}, 1 \mathrm{H}), 4.67(\mathrm{~m}, J=13.0$, $5.7 \mathrm{~Hz}, 1 \mathrm{H}), 4.41(\mathrm{~d}, J=7.2 \mathrm{~Hz}, 2 \mathrm{H}), 4.24(\mathrm{t}, J=7.1 \mathrm{~Hz}, 1 \mathrm{H}), 3.31-3.08(\mathrm{~m}, 2 \mathrm{H}), 1.48(\mathrm{~s}, 9 \mathrm{H})$.

${ }^{13} \mathrm{C}$ NMR $\left(126 \mathrm{MHz}, \mathrm{CDCl}_{3}\right) \delta 174.48,170.12,164.71,156.34,143.84,143.72,141.35,127.81$, 127.17, 125.25, 120.05, 82.67, 77.16, 67.48, 60.71, 53.69, 47.11, 35.49, 34.62, 28.01. 
NMR spectra:

Compound DS-2 ${ }^{1} \mathrm{H}$ NMR

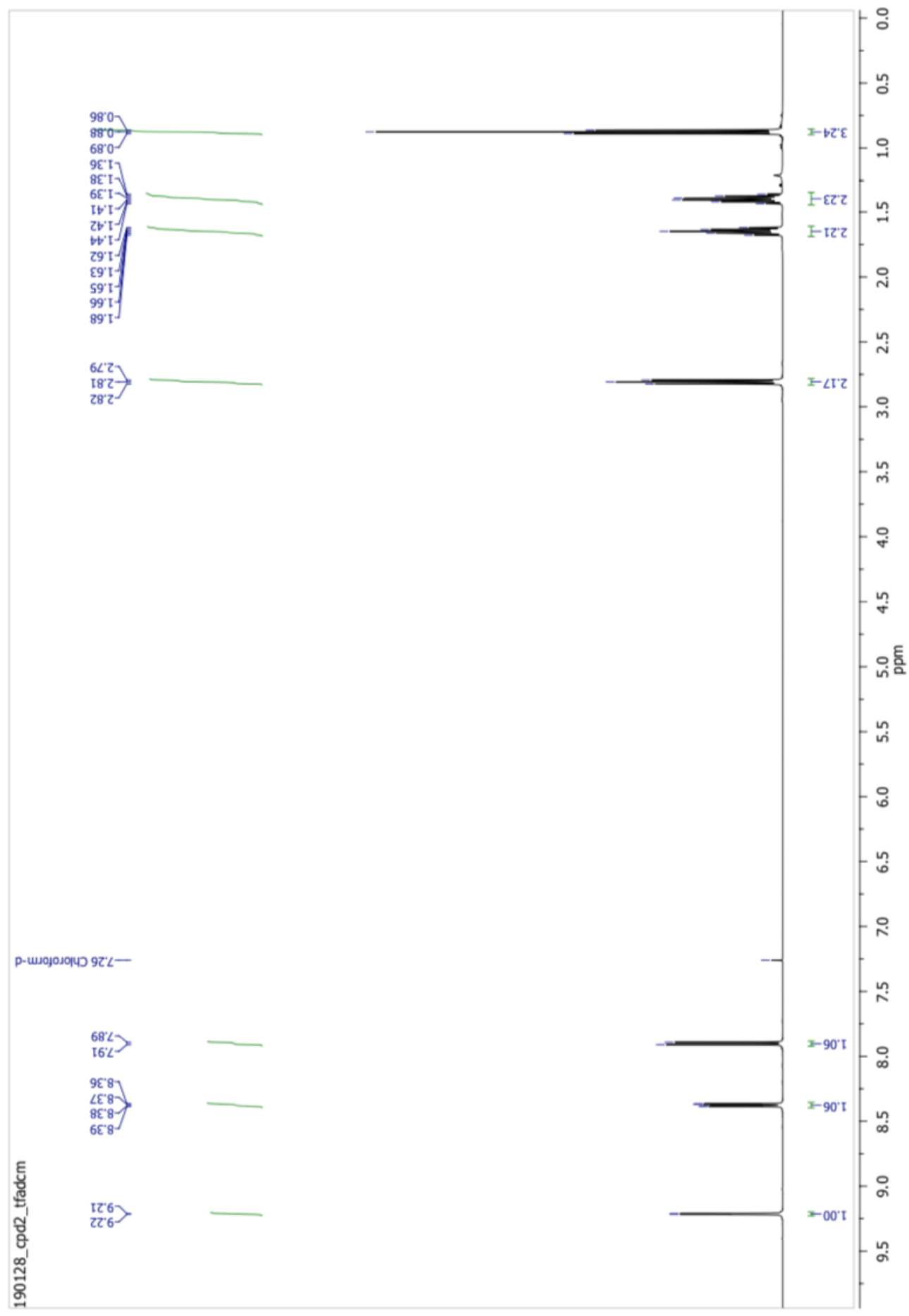


Compound DS-2 ${ }^{13} \mathrm{C}$ NMR

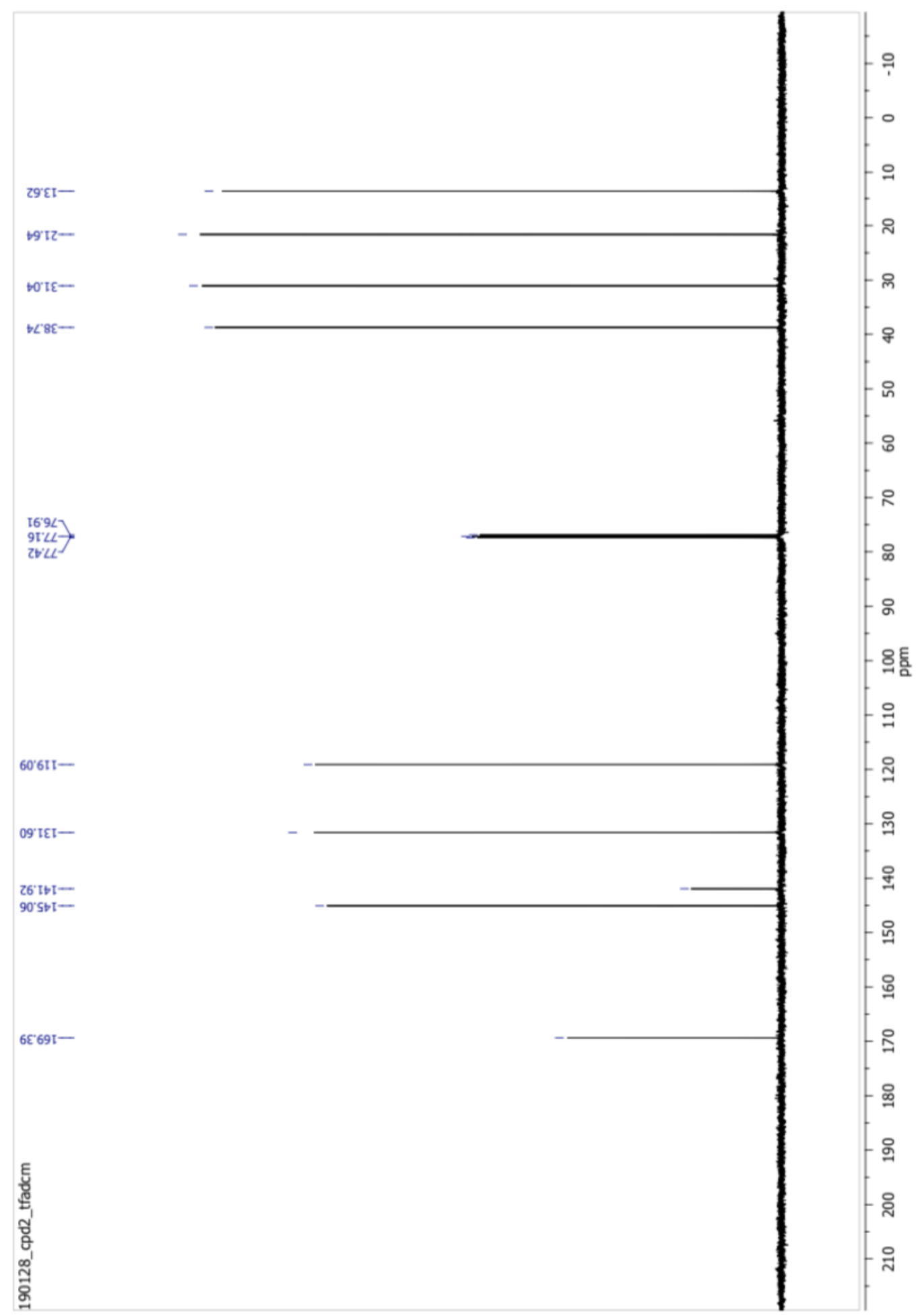


Compound $1 \mathrm{~A}^{1} \mathrm{H}$ NMR

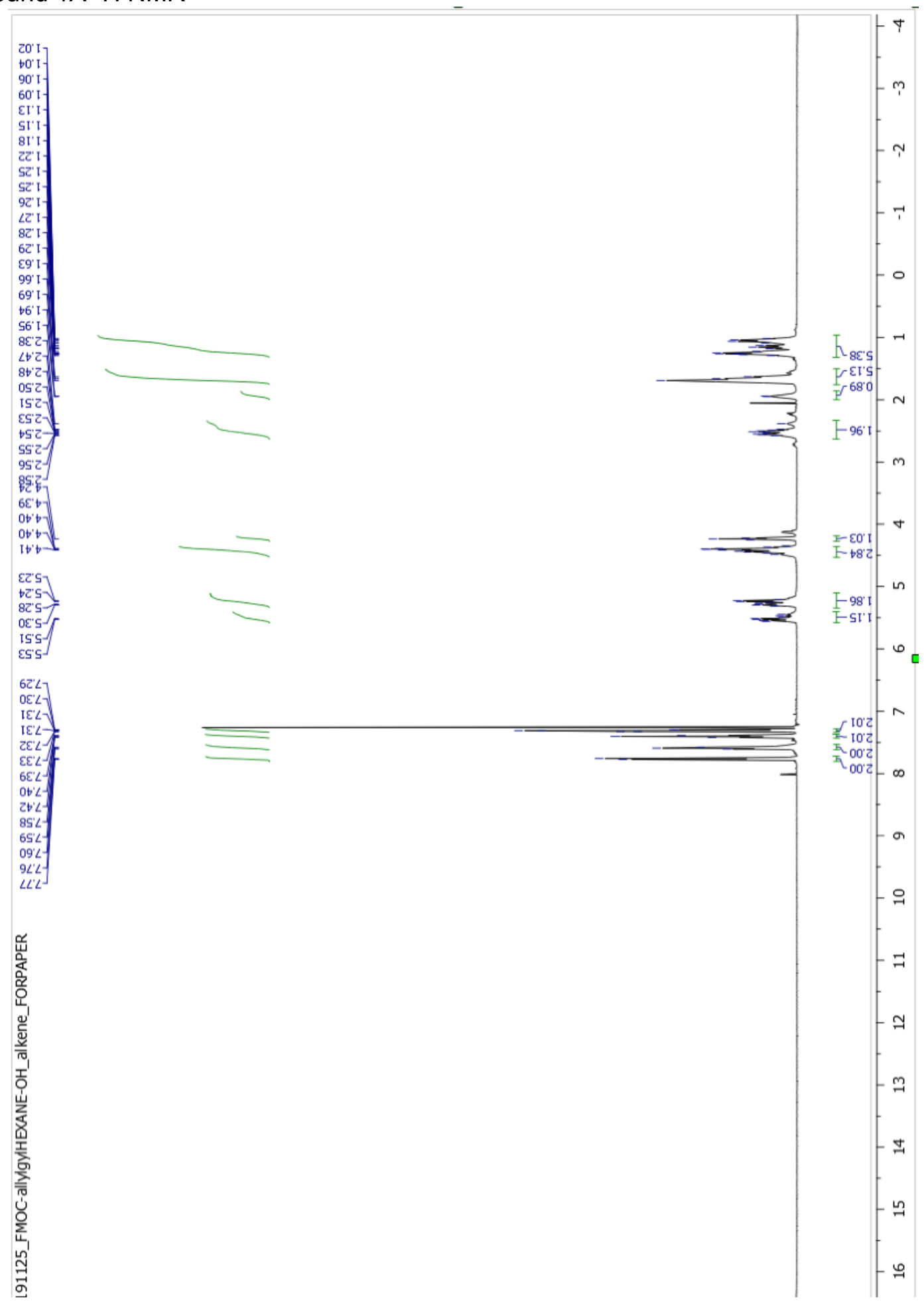


Compound $1 \mathrm{~A}{ }^{13} \mathrm{C}$ NMR

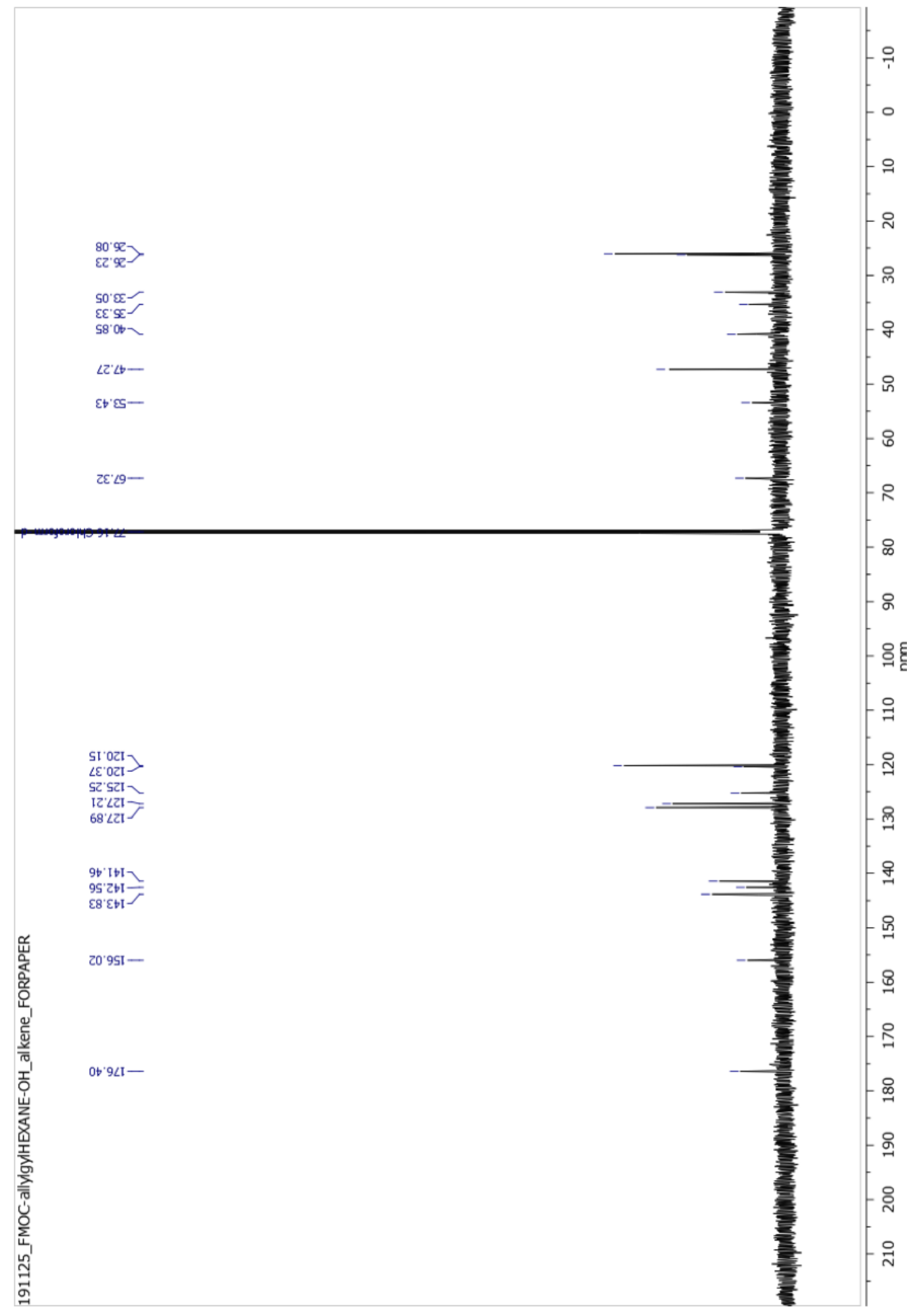


Compound 1B ${ }^{1} \mathrm{H}$ NMR

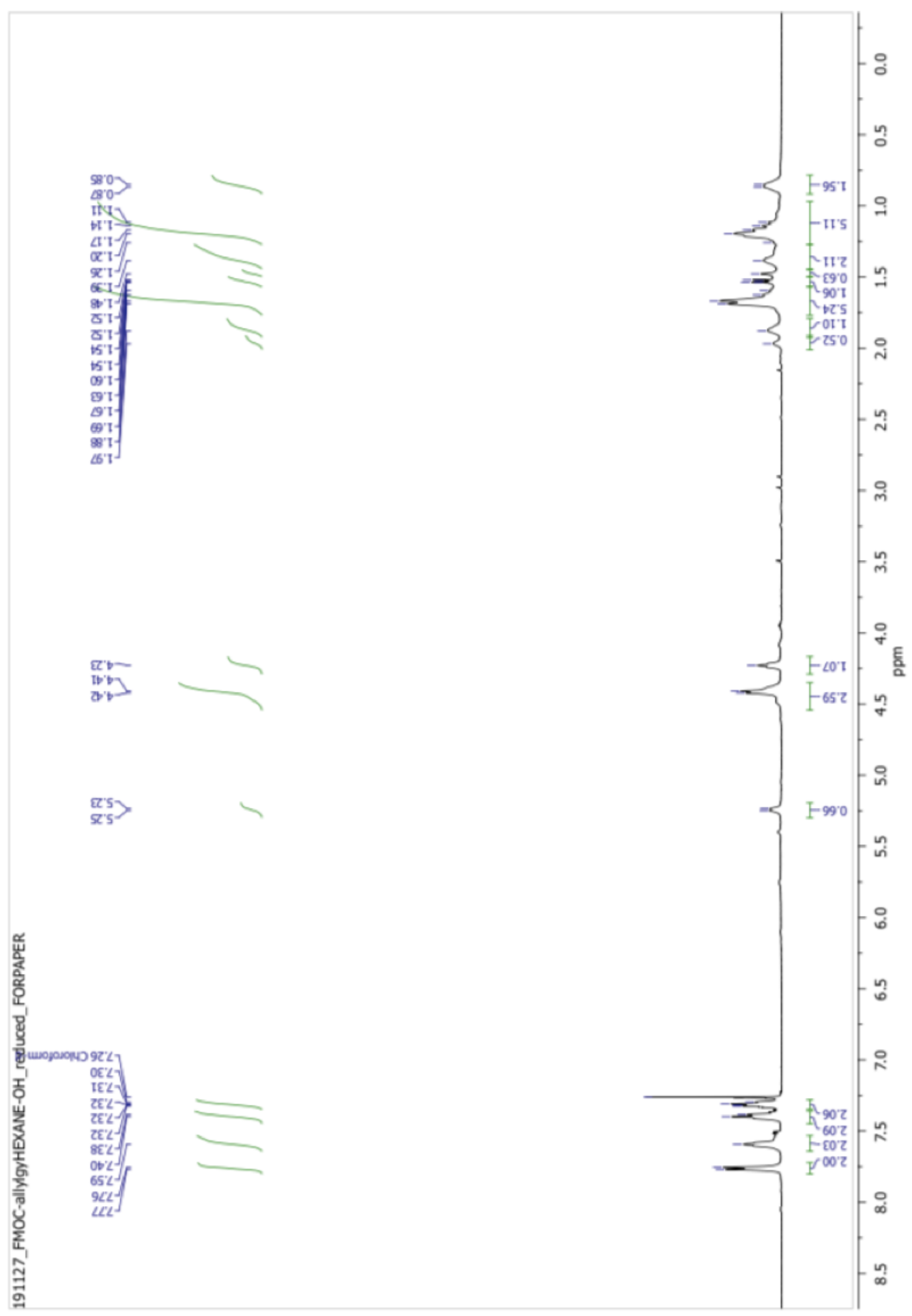


Compound $1 \mathrm{~B}{ }^{13} \mathrm{C}$ NMR

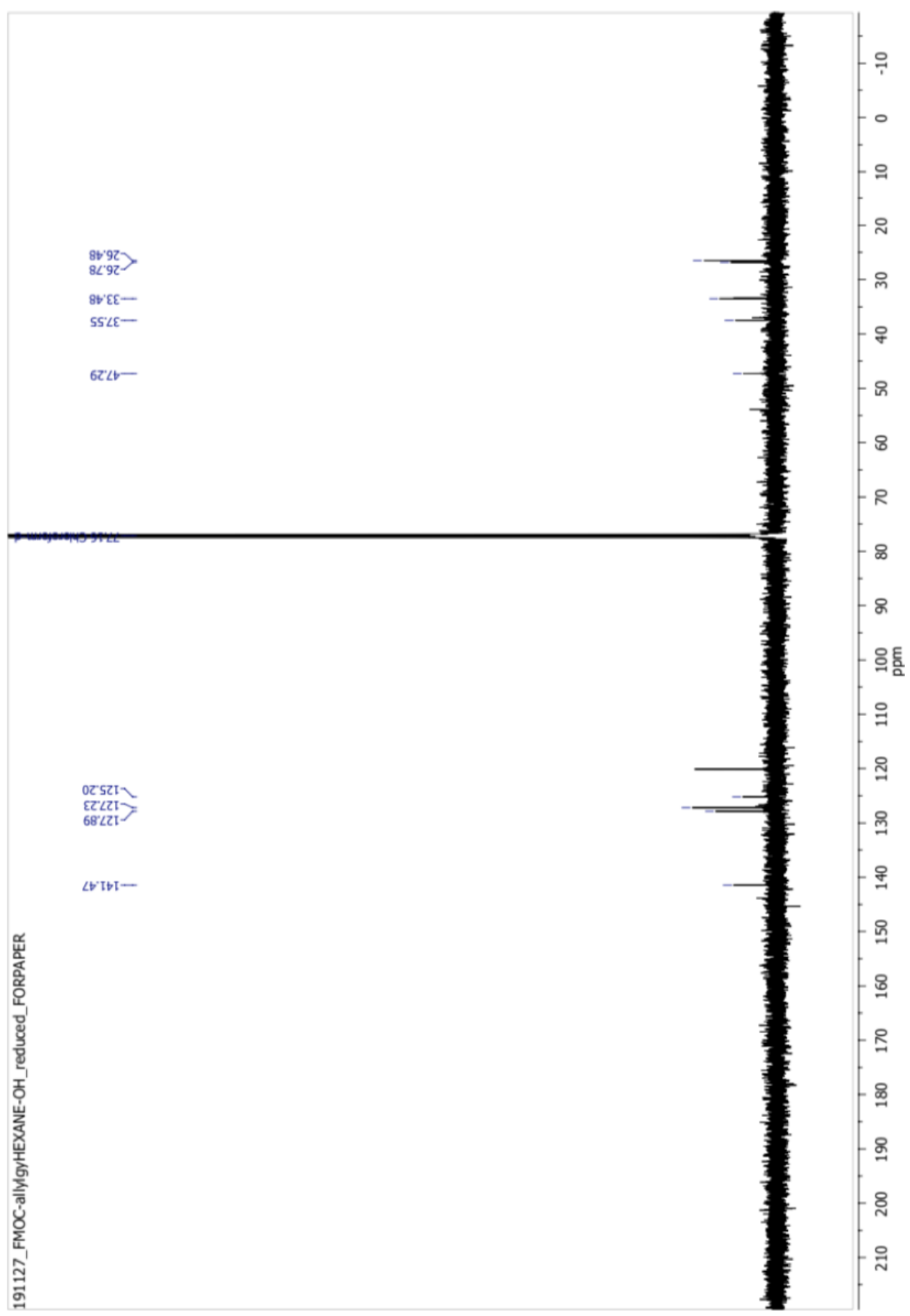


Compound $2 \mathrm{~A}^{1} \mathrm{H}$ NMR

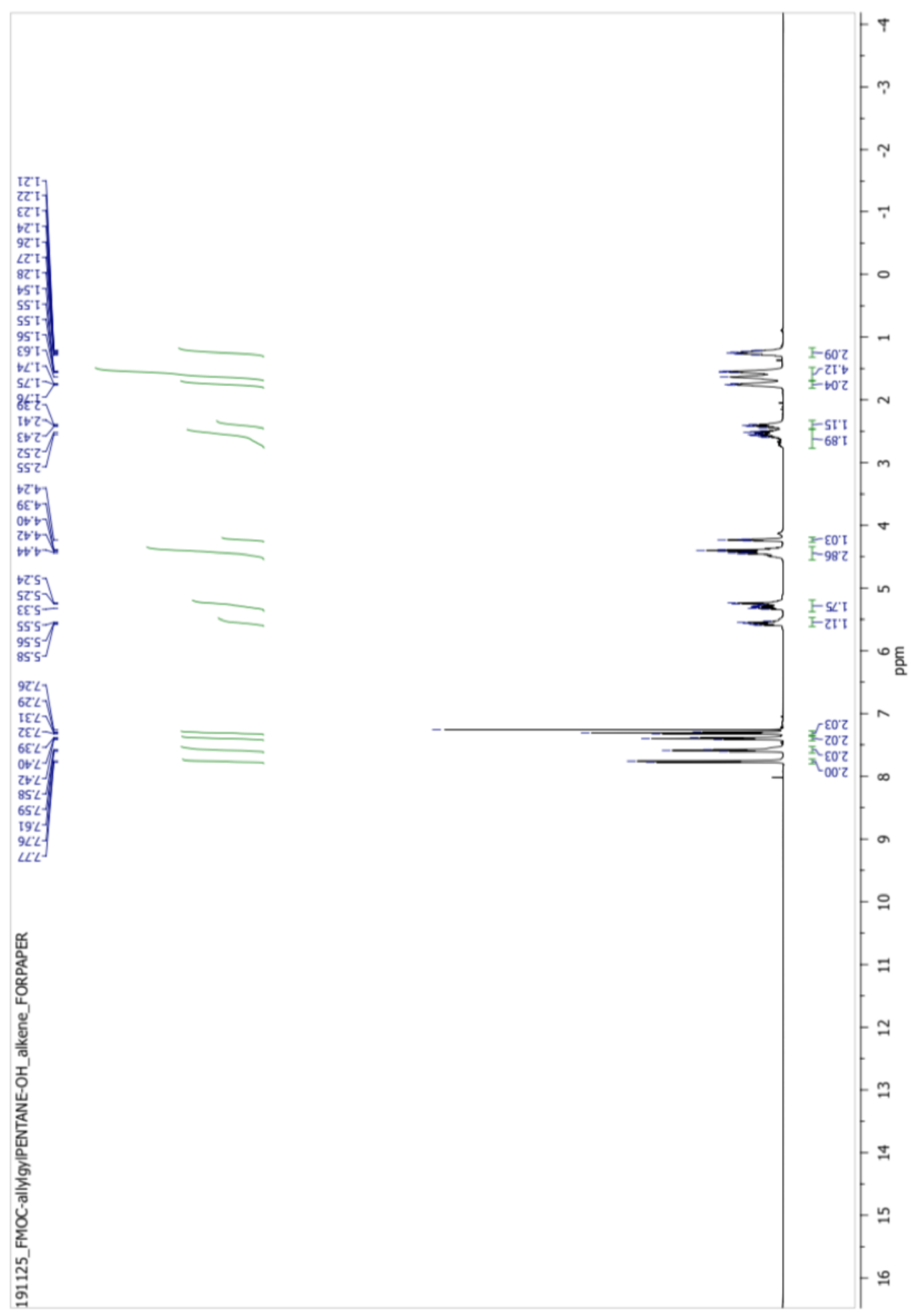


Compound $2 \mathrm{~A}{ }^{13} \mathrm{C}$ NMR

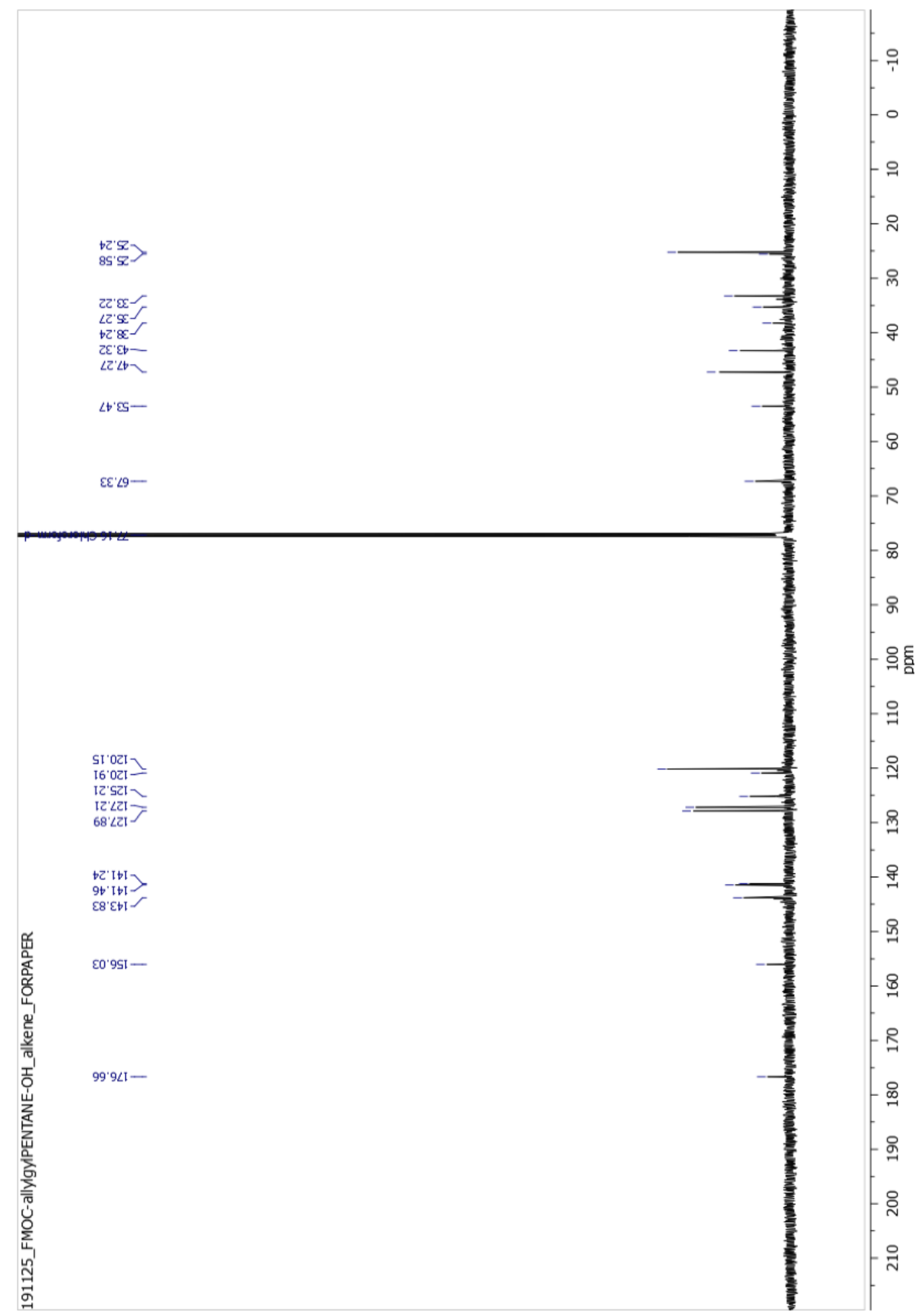


Compound $2 \mathrm{~B}^{1} \mathrm{H}$ NMR

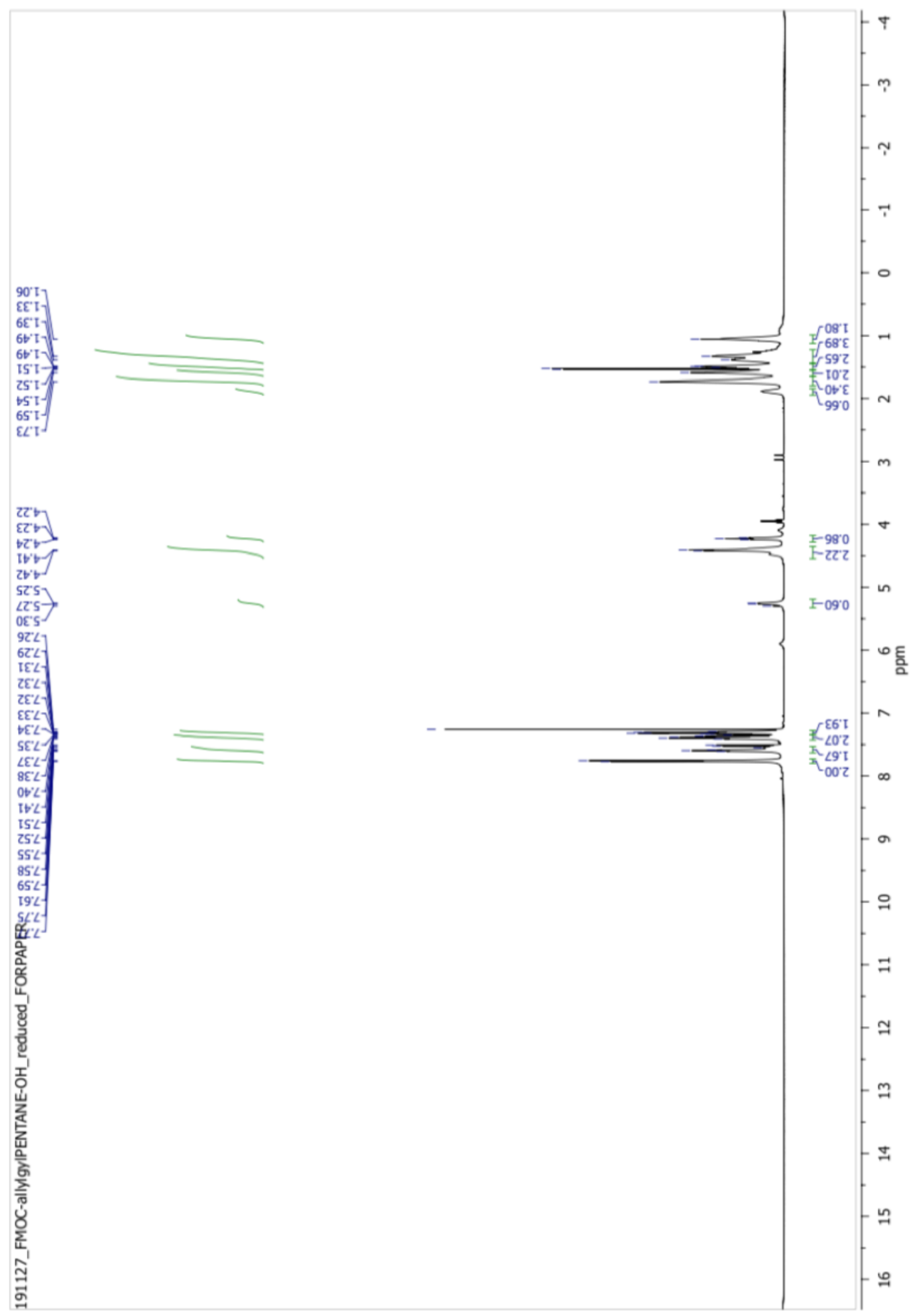


Compound $2 \mathrm{~B}{ }^{13} \mathrm{C}$ NMR

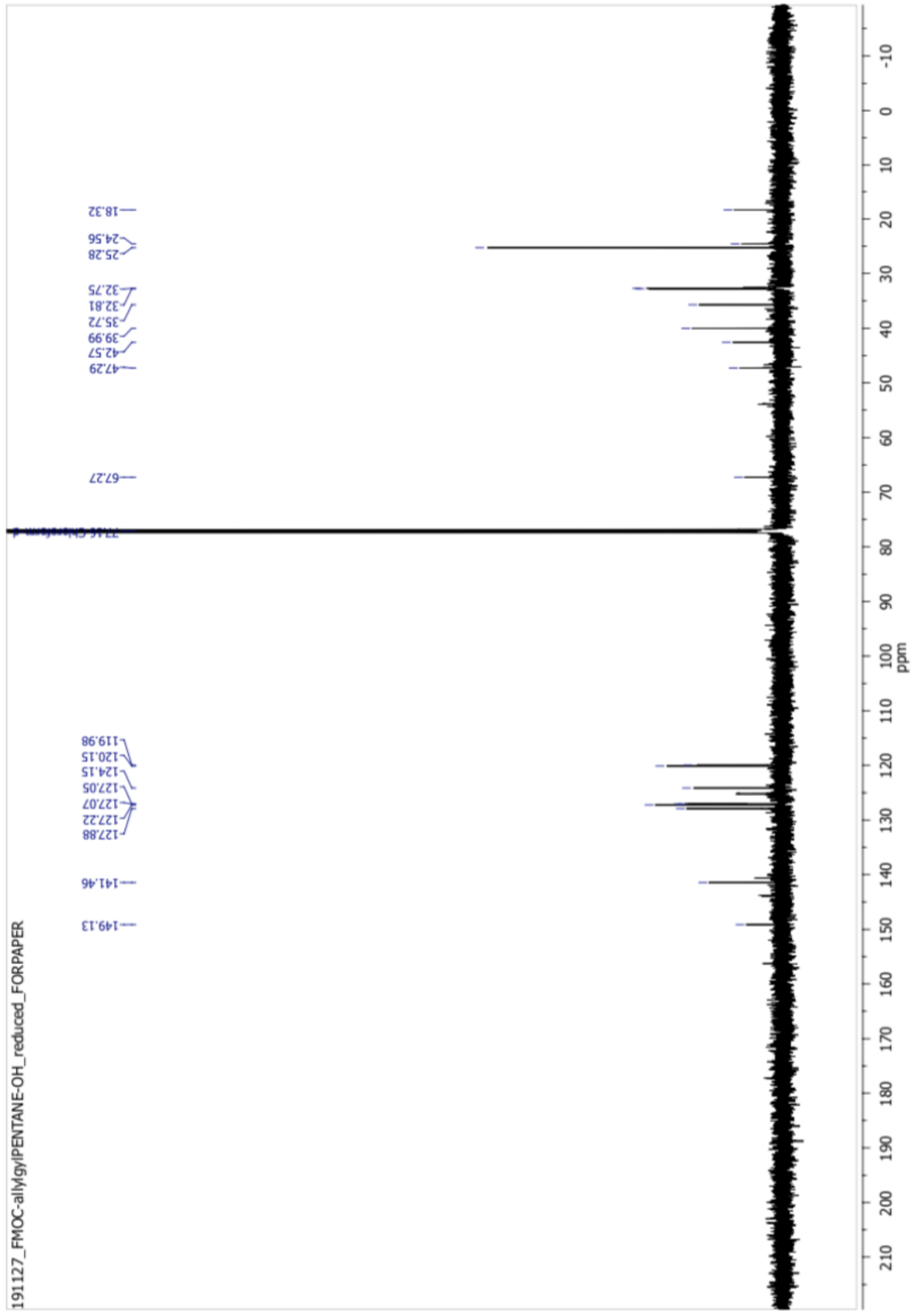


Compound $3{ }^{1} \mathrm{H}$ NMR

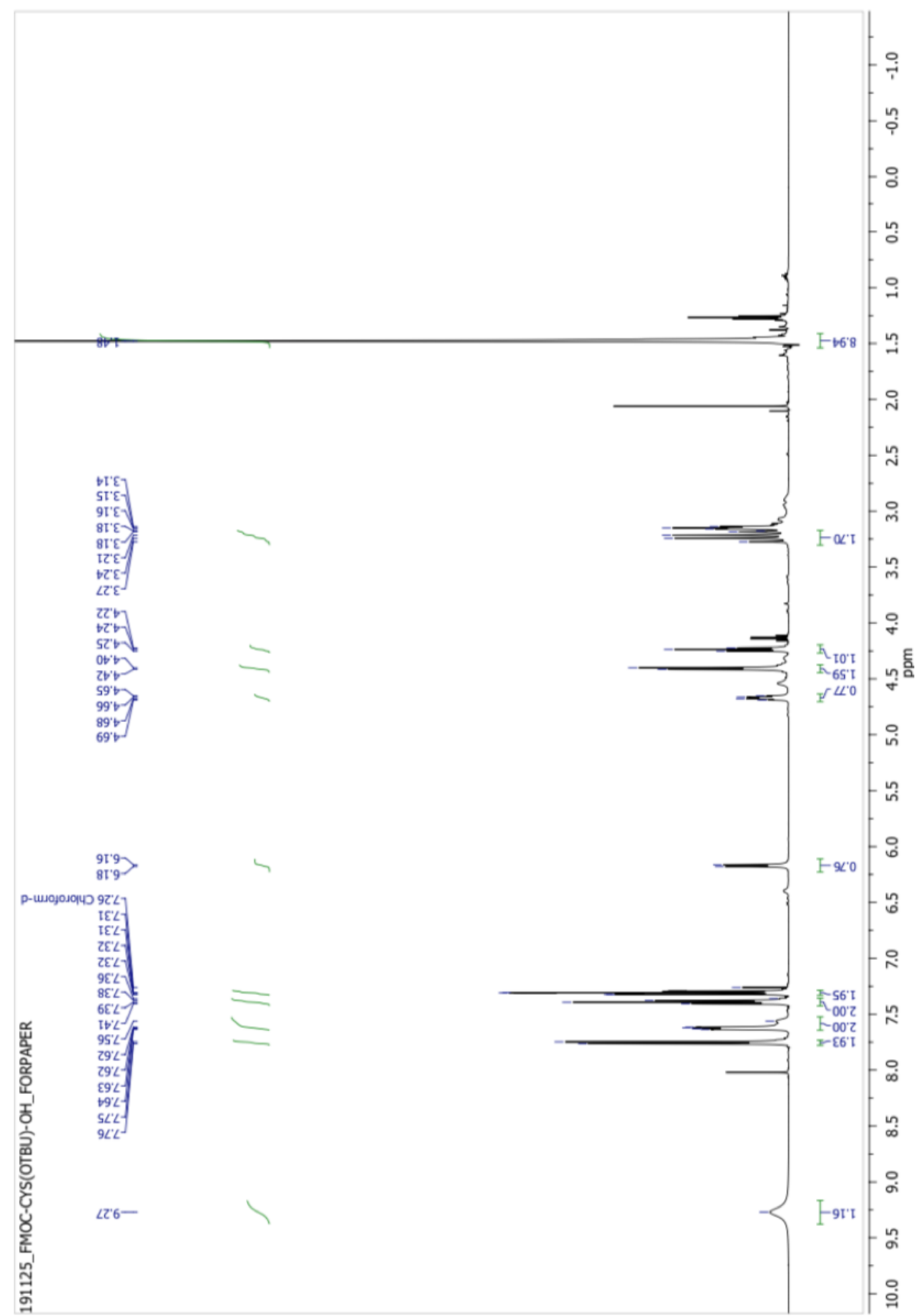


Compound $3{ }^{13} \mathrm{C}$ NMR

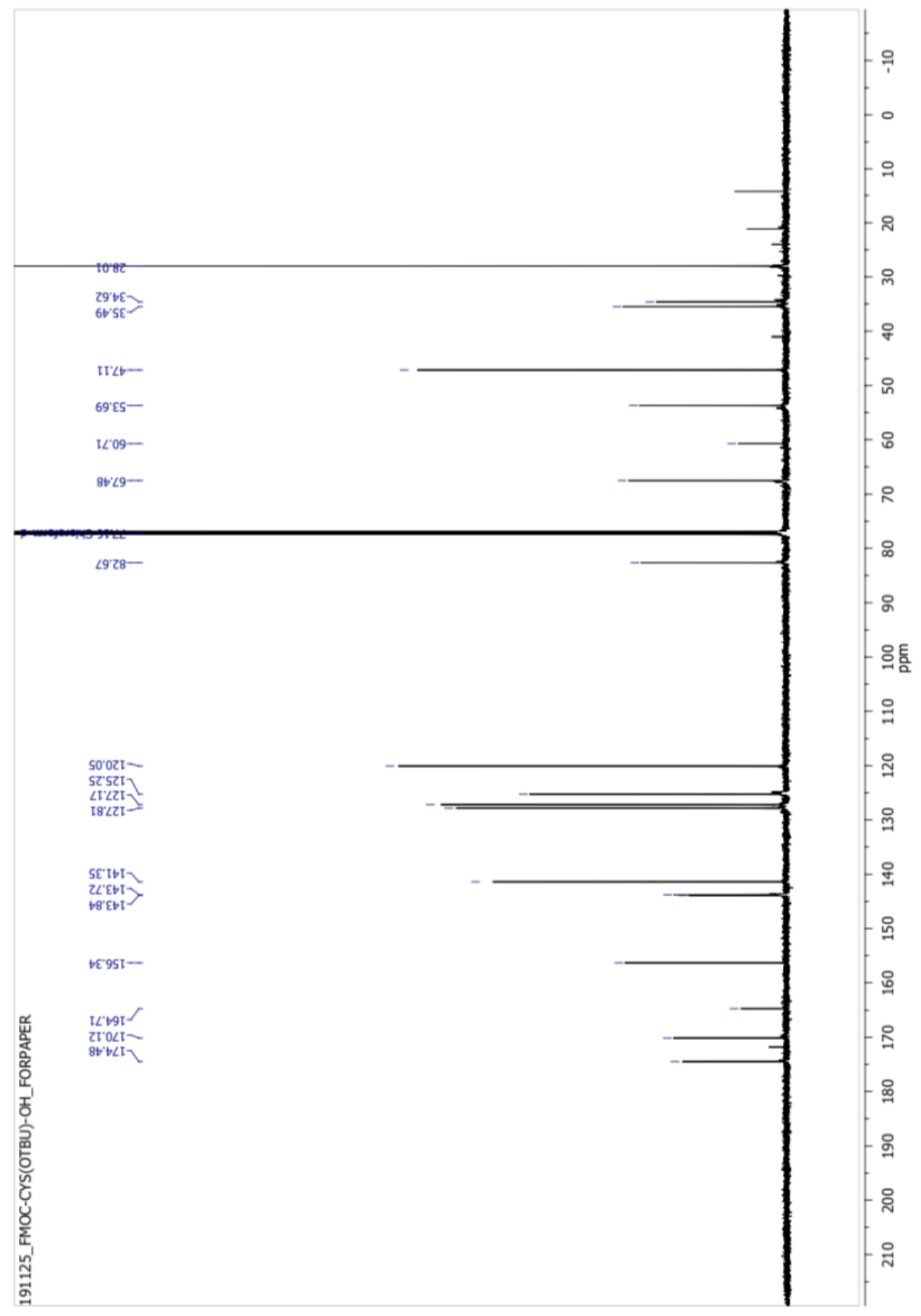




\section{J. Alkylation Test Reactions Methods General Alkylation Reaction Procedure:}

Each alkylator was prepared and tested on the peptide individually. The HBS I_850_screen peptide $\left(\mathrm{XSDG}^{*} \mathrm{CD}(2 \mathrm{meF})\right.$ ILKNYPW(K-5-FAM)- $\mathrm{NH}_{2}$ ) was used in all test reactions. For each test reaction, the fluorescent peptide was brought up in $60 \% 50 \mathrm{mM}$ ammonium bicarbonate, $\mathrm{pH} 8.0$ in $40 \%$ acetonitrile. The peptide's concentration was adjusted to $180 \mu \mathrm{M}$ using $\mathrm{E}_{494}=77,000$ $\mathrm{L} \cdot \mathrm{mol}^{-1} \cdot \mathrm{cm}^{-1}$. Concentrations of protein and peptide samples were determined using Nanodrop 2000c (ThermoScientific). Each alkylator was prepared individually to have a stock concentration of $4.5 \mathrm{mM}$ in $100 \%$ acetonitrile. $2 \mu \mathrm{L}$ of alkylator and $10 \mu \mathrm{L}$ of 5-FAM-peptide were mixed in an Eppendorf so that the final concentration of the peptide in the well was $150 \mu \mathrm{M}$, and the alkylators were present at $5 \mathrm{X}$ the concentration at $750 \mu \mathrm{M}$. The final mixture yielded $50 / 50$ acetonitrile/50 $\mathrm{mM}$ ammonium bicarbonate, $\mathrm{pH}$ 8.0. The reaction was agitated in the dark at room temperature. Alkylators containing benzyl bromide moieties or iodoacetamide (IAM) or iodoacetic acid (IAA) were purchased. Asymmetric disulfide compounds were synthesized and used crude with the exception of the purified compound DS2 to confirm that the crude alkylator produces the same results as the purified alkylator.

\section{General Analysis Procedure:}

Time points were removed from the test reaction at $0,30,60$ and 90 minutes for Bruker UltrafleXtreme MALDI-TOF analysis. The sample was prepared by mixing the reaction with the $\alpha$-cyano-4-hydroxycinnamic acid matrix, which was dissolved in 50/50 acetonitrile/water with $0.1 \%$ TFA. The peaks next to the labeled peaks are the $\mathrm{Na}^{+}$adduct and not labeled for clarity. Additionally, at the 90-minute time point, the sample was diluted with water and analyzed by analytical HPLC (C-18, $3.5 \mu \mathrm{m}, 2.1 \times 150 \mathrm{~mm})$ using a $5-95 \%$ acetonitrile in water with $0.1 \%$ TFA gradient over 15 minutes. Both analytical techniques subject the sample to $0.1 \%$ TFA, which lowers the $\mathrm{pH}$ and thus quenches the reaction. A representative analytical HPLC trace of the sample peptide at $\mathrm{t}=0$ (with no alkylator) is shown below. 


\section{K. Alkylation Test Reactions Results}

For all test reactions, HBS I_850_Screen was used.

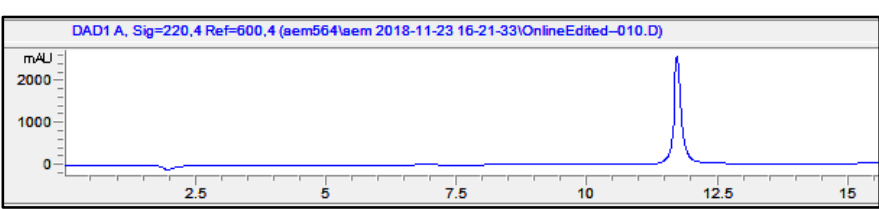

Figure S8: HPLC trace of peptide with no alkylator.

\section{Bromide Alkylation}

The benzyl bromide alkylation took place according to the general alkylation procedure. The MALDI-TOF analysis confirms that no disulfides were formed and alkylation only occurred once (there is no double alkylation). The starting material is consumed in 60 minutes.

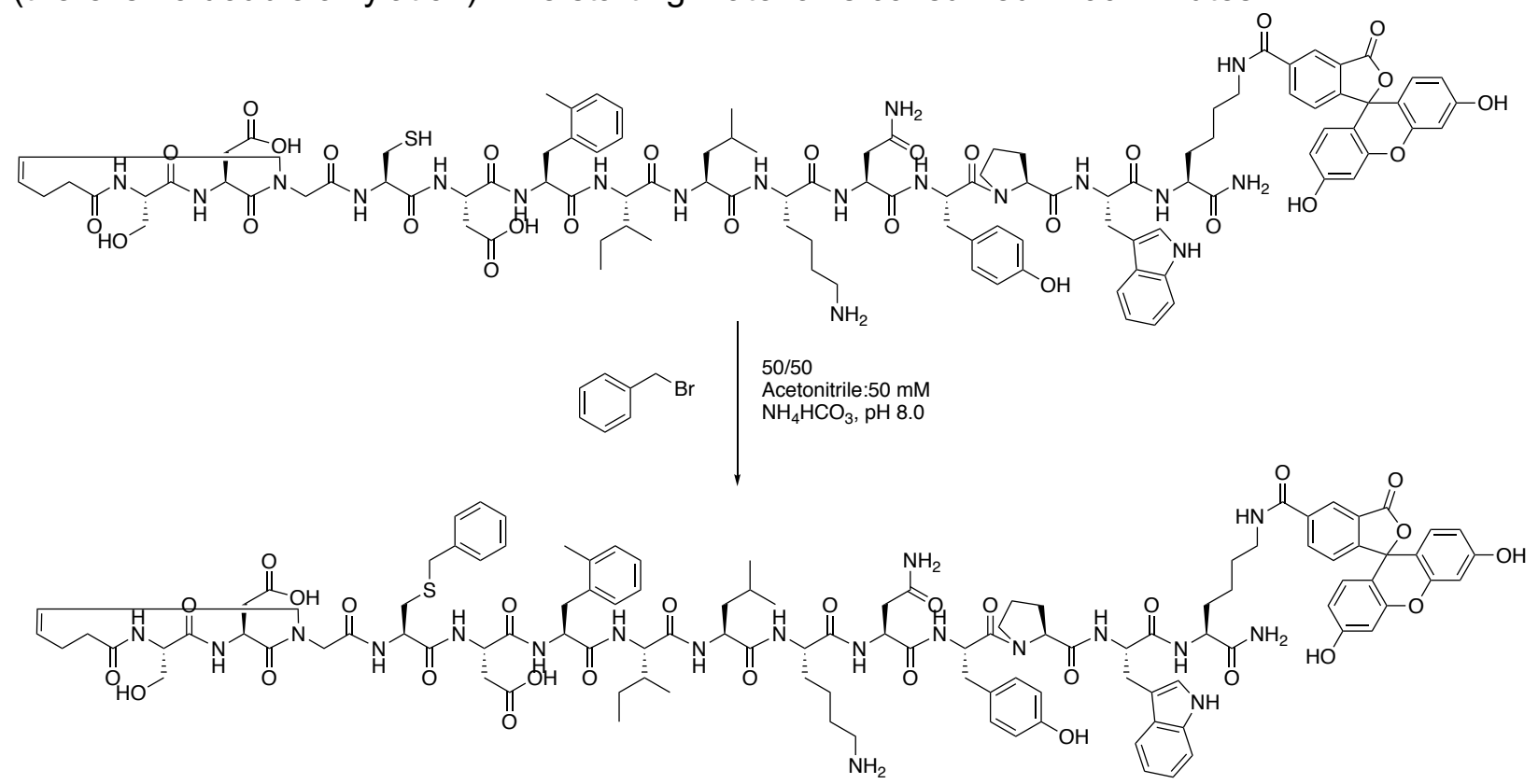

Scheme S9: Benzyl bromide test reaction scheme. 


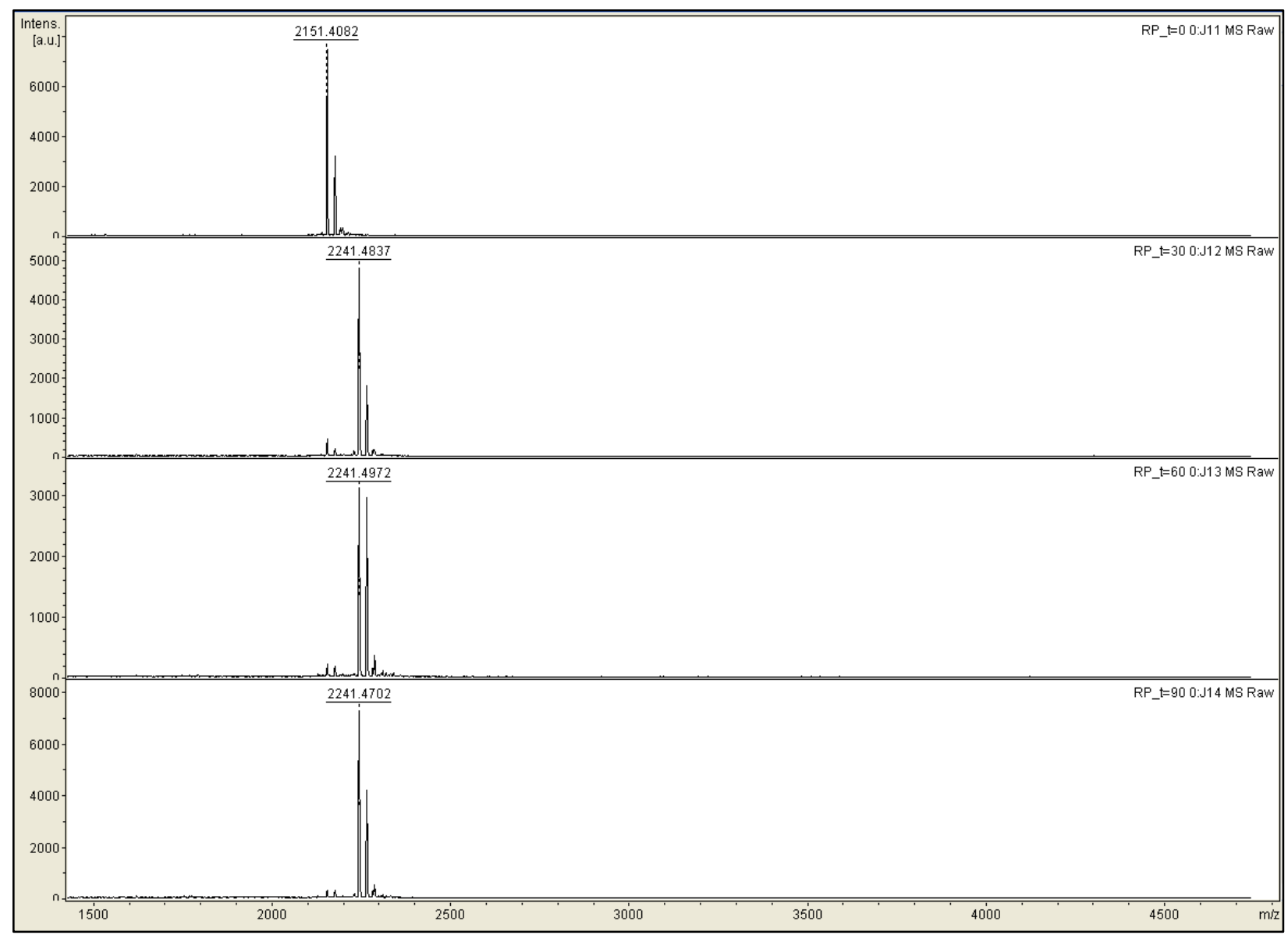

Figure S9: MALDI-TOF data of benzyl bromide test reaction. Masses showing time = 0 minutes (top), followed by 30 minutes, 60 minutes and 90 minutes.

Table S5: Summary of benzyl bromide $(\mathrm{BnBr})$ alkylation test reaction masses.

\begin{tabular}{|c|c|c|}
\hline Compound & Expected Mass $[\mathbf{M + H}]^{+}$ & ${\text {Observed Mass }[\mathbf{M + H}]^{+}}^{+}$ \\
\hline Starting peptide (Free Thiol) & 2150.913 & 2151.408 \\
\hline Peptide + BnBr Product & 2240.960 & 2241.470 \\
\hline Change in mass & 90.047 & 90.062 \\
\hline
\end{tabular}

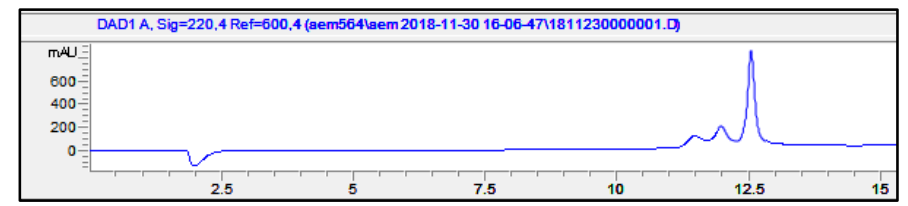

Figure S10: HPLC trace of alkylated peptide of benzyl bromide. 


\section{lodoacetamide Alkylation}

The iodoacetamide alkylation took place according to the general alkylation procedure. The MALDI confirms that no disulfides were formed and alkylation only happed once (there is no double alkylation). The starting material is consumed in 30 minutes.

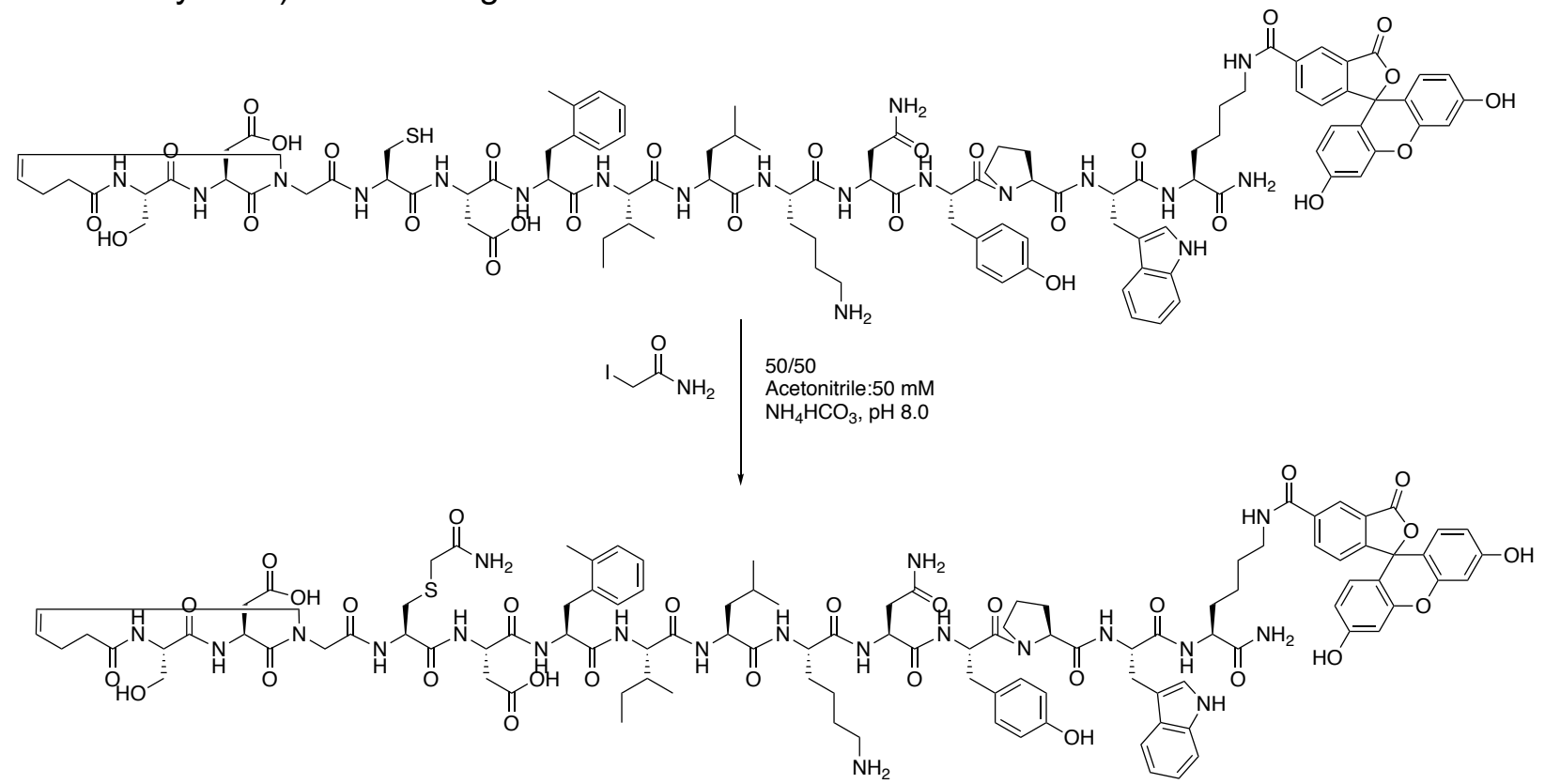

Scheme S10: lodoacetamide test reaction scheme. 


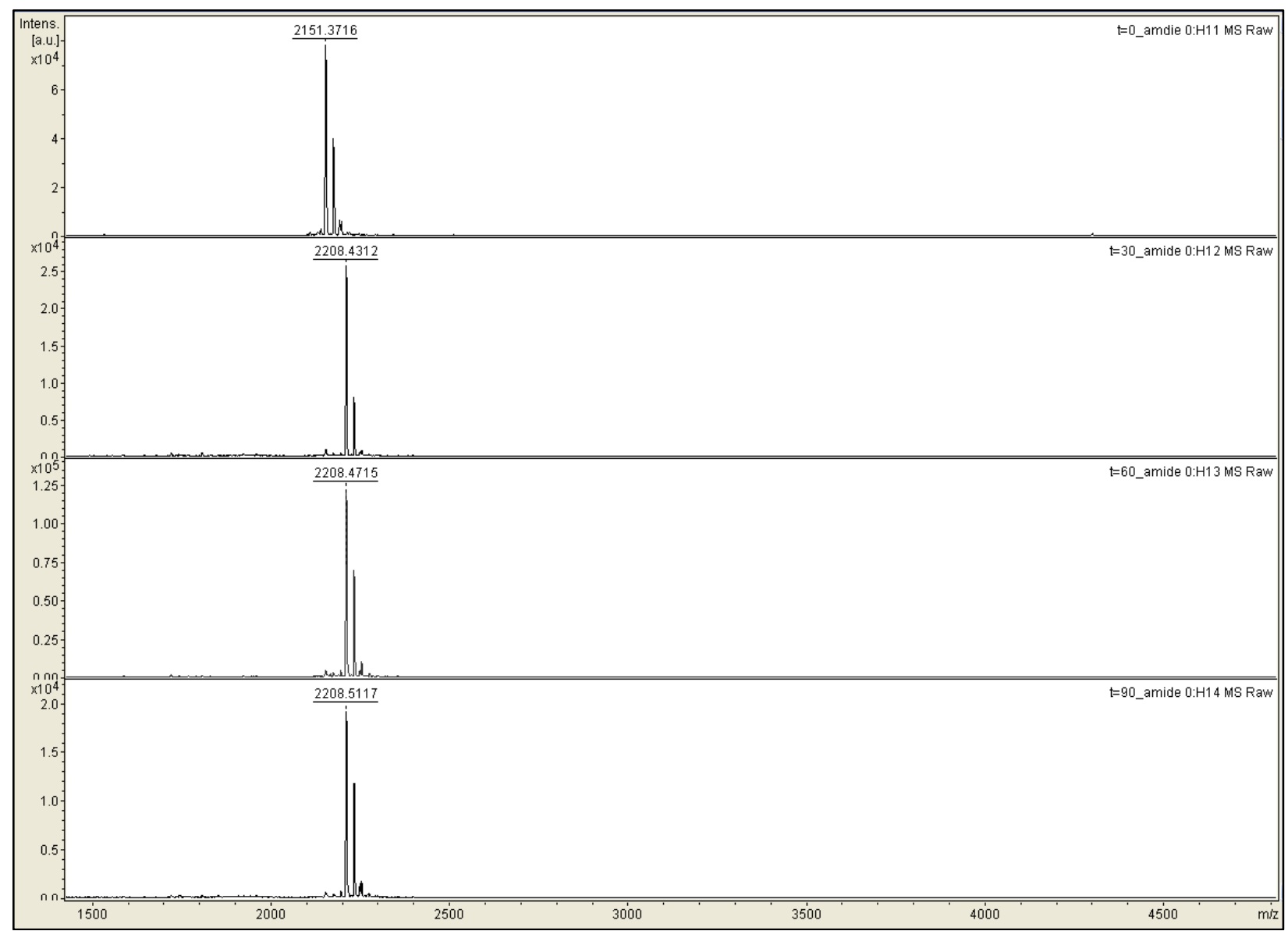

Figure S11: MALDI-TOF data of iodoacetamide test reaction. Masses showing time $=0$ minutes (top), followed by 30 minutes, 60 minutes and 90 minutes.

Table S6: Summary of iodoacetamide (IAM) alkylation test reaction masses.

\begin{tabular}{|c|c|c|}
\hline Compound & Expected Mass $[\mathbf{M + H}]^{+}$ & ${\text {Observed Mass }[\mathbf{M}+\mathbf{H}]^{+}}^{+}$ \\
\hline Starting peptide (Free Thiol) & 2150.913 & 2151.372 \\
\hline Peptide + IAM Product & 2207.935 & 2208.512 \\
\hline Change in mass & 57.021 & 57.140 \\
\hline
\end{tabular}

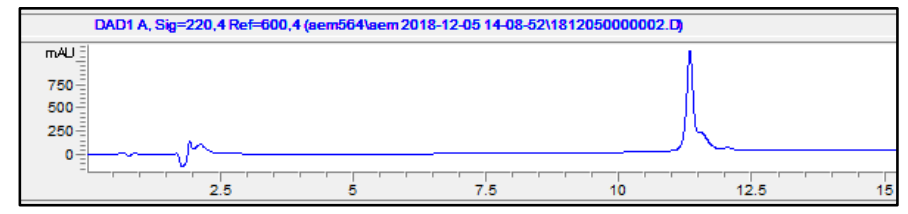

Figure S12: HPLC trace of alkylated peptide of iodoacetamide. 


\section{lodoacetic Acid Alkylation}

The iodoacetamide alkylation took place according to the general alkylation procedure. The MALDI confirms that no disulfides were formed and alkylation only happed once (there is no double alkylation). The reaction is completed in 90 minutes.

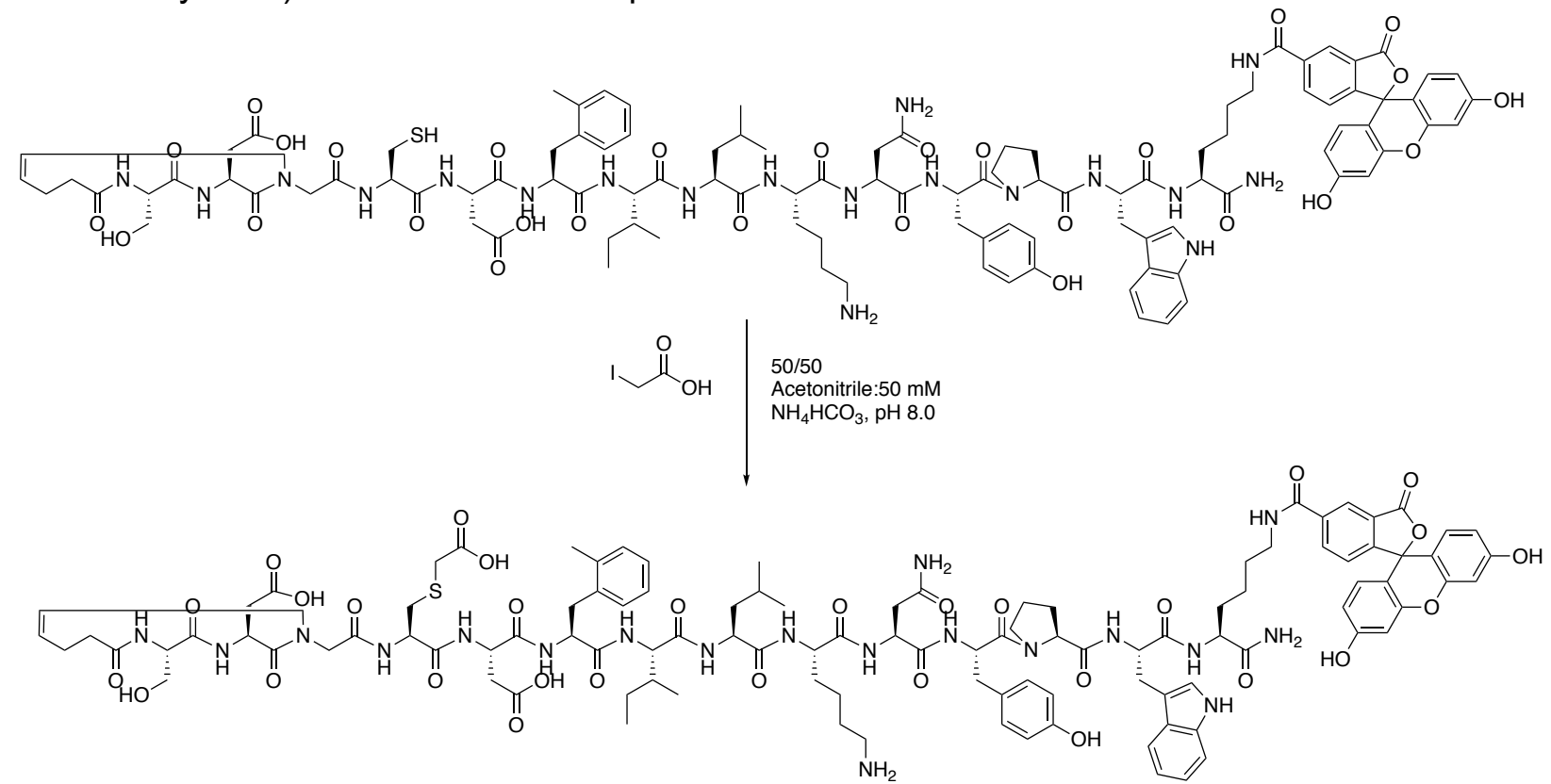

Scheme S11: lodoacetic acid test reaction scheme. 


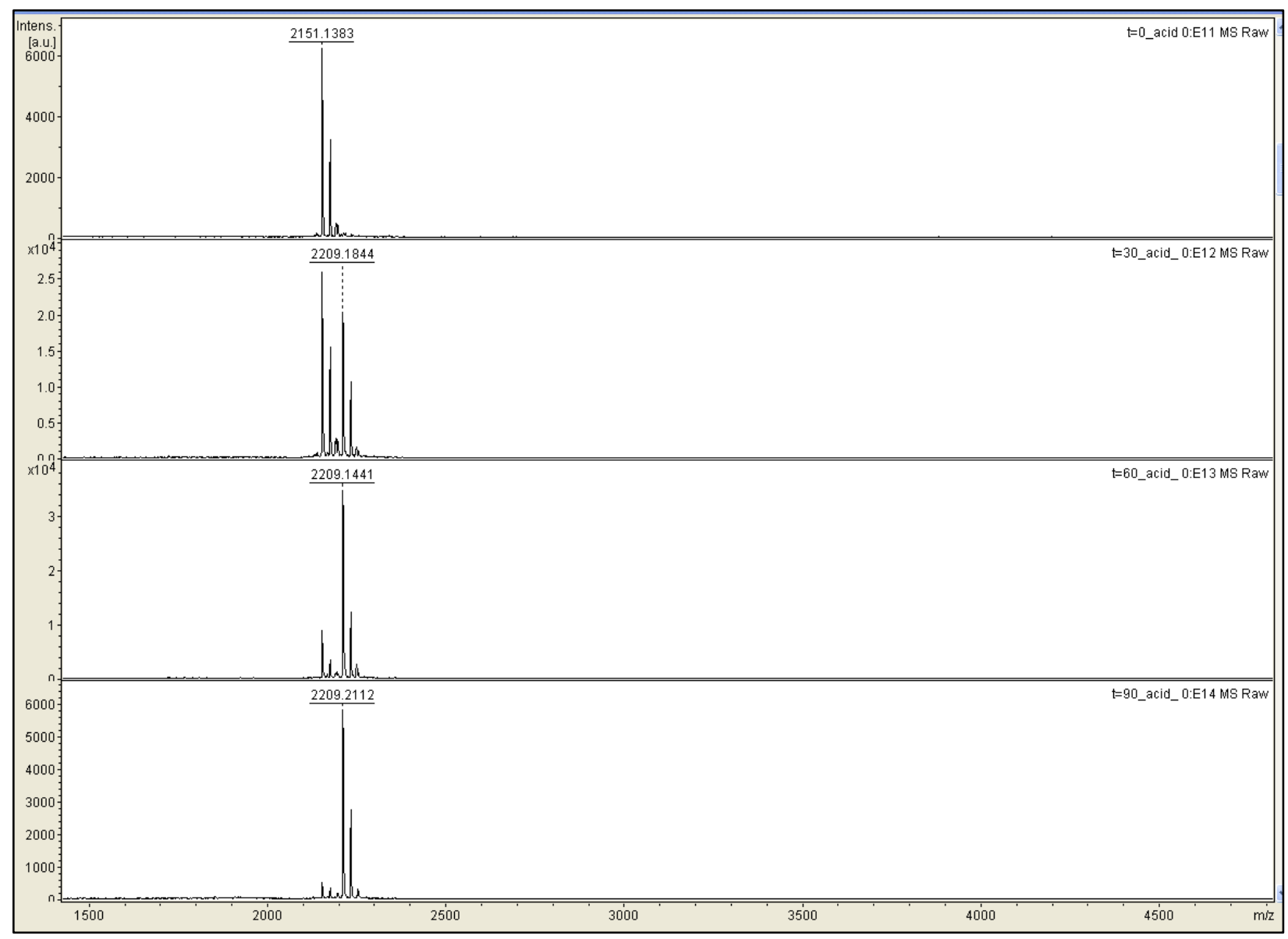

Figure S13: MALDI-TOF data of iodoacetic acid test reaction. Masses showing time $=0$ minutes (top), followed by 30 minutes, 60 minutes and 90 minutes.

Table S7: Summary of iodoacetic acid (IAA) alkylation test reaction masses.

\begin{tabular}{|c|c|c|}
\hline Compound & Expected Mass $[\mathbf{M + H}]^{+}$ & Observed Mass $[\mathbf{M + H}]^{+}$ \\
\hline Starting Peptide (Free Thiol) & 2150.913 & 2151.138 \\
\hline Peptide + IAA Product & 2208.919 & 2209.211 \\
\hline Change in mass & 58.005 & 58.073 \\
\hline
\end{tabular}

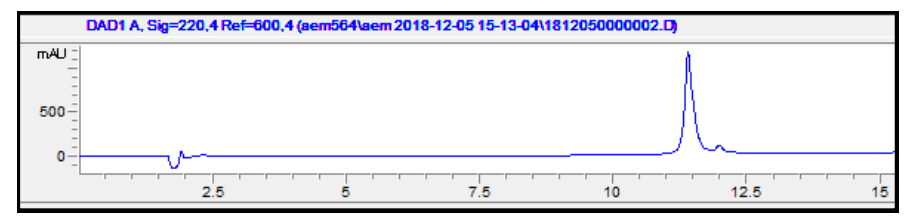

Figure S14: HPLC trace of alkylated peptide of iodoacetic acid. 


\section{Activated Disulfide Alkylation}

The disulfide alkylation took place according to the general alkylation procedure. The MALDI confirms that no disulfides were formed and alkylation only happed once (there is no double alkylation). The reaction is completed in 90 minutes. The crude disulfide mass was calculated as $4.5 \mathrm{mM}$ of the total weight of the crude product (i.e.,DS-2: $244.0340+155.9993 \mathrm{~g} / \mathrm{mol}$ ) to account for the side product produced at 1 equivalent. The 0.2 eq. of thiol leftover is accounted as negligible since it is most likely evaporated off after concentration of the crude compound.

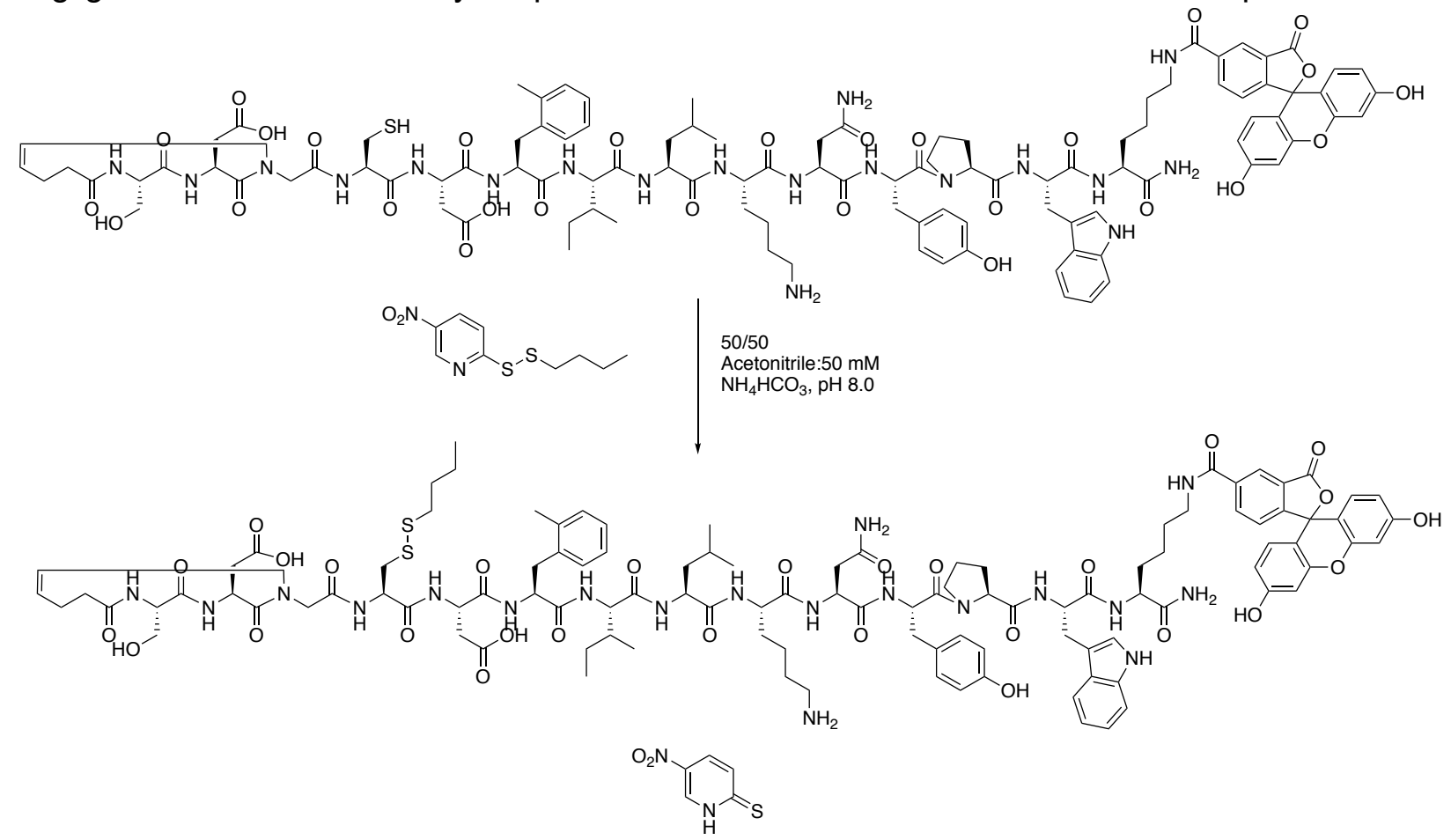

Scheme S12: Activated disulfide test reaction scheme. 


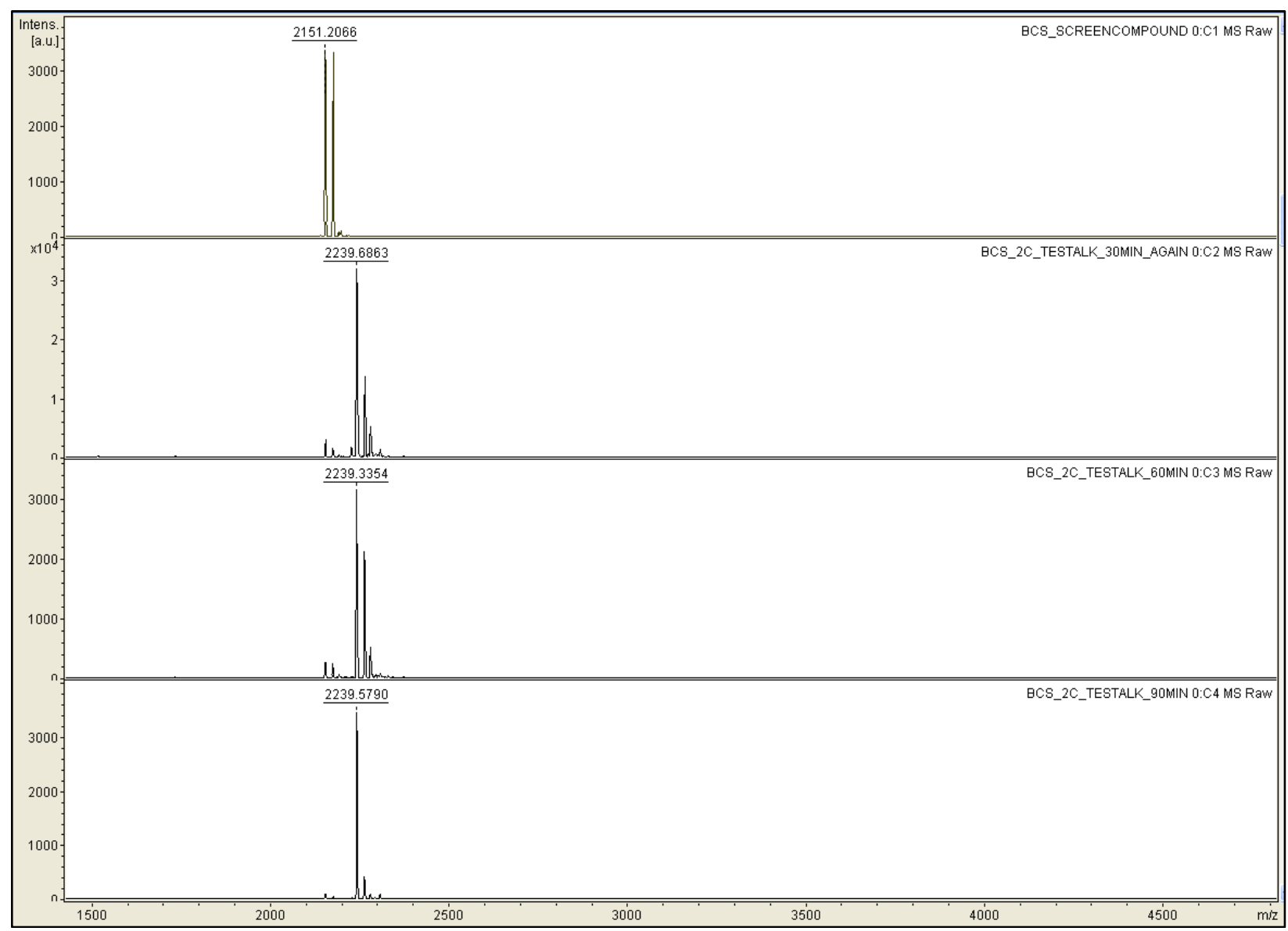

Figure S15: MALDI-TOF data of disulfide test reaction. Masses showing time $=0$ minutes (top), followed by 30 minutes, 60 minutes and 90 minutes.

Table S8: Summary of disulfide alkylation test reaction masses.

\begin{tabular}{|c|c|c|}
\hline Compound & Expected Mass $[\mathbf{M + H}]^{+}$ & ${\text {Observed Mass }[\mathbf{M + H}]^{+}}^{+}$ \\
\hline Starting Peptide (Free Thiol) & 2150.913 & 2151.207 \\
\hline Peptide + DS Product & 2238.948 & 2239.57 \\
\hline Change in mass & 88.035 & 88.366 \\
\hline
\end{tabular}

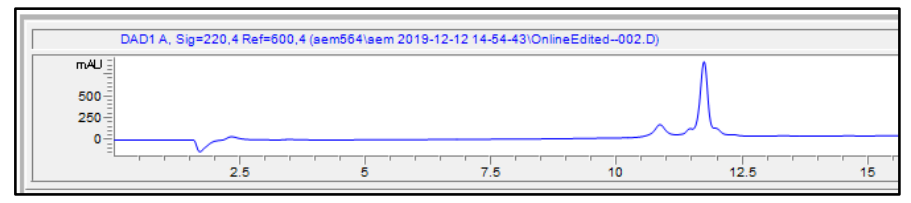

Figure S16: HPLC trace of alkylated peptide with disulfide using pure DS2. 


\section{Screening Assay Methods General Screening Protocol:}

Alkylators were prepared as performed in the test reactions with a final concentration of peptide at $150 \mu \mathrm{M}$ and alkylator at $750 \mu \mathrm{M}$. All reactions proceeded for 90 minutes (the time it takes for all test reactions to be completed). Upon completion of the reaction (confirmed by MALDI-TOF consumption of starting material), each alkylated peptide was diluted in PBS pH 7.4 with $10 \%$ glycerol and $0.1 \%$ Pluronic acid F-127 (Sigma) to a concentration of $30 \mathrm{nM}$. Equal amounts of alkylated peptide and KIX protein were mixed to produce $15 \mathrm{nM}$ of alkylated peptide in the well with $40 \mu \mathrm{M}$ of $\mathrm{KIX}$ in triplicate in a 384 well plate format. The alkylators were also mixed with buffer (PBS pH 7.4 with $10 \%$ glycerol and $0.1 \%$ Pluronic acid) for a blank reading in triplicate. Fluorescence polarization was read after 60 minutes. The blank reading for each alkylated peptide was averaged and subtracted from the experiment wells. Screens were performed in triplicate and repeated at least once.

\section{Initial disulfide crude versus pure disulfide test:}

The pure disulfide mass was calculated as the purified product $(244.0340 \mathrm{~g} / \mathrm{mol})$ in the test reaction and the screen protocol was used to compare the crude disulfide alkylator with the purified one. Results are within error and confirm that the crude alkylator produces similar results to the purified alkylator.

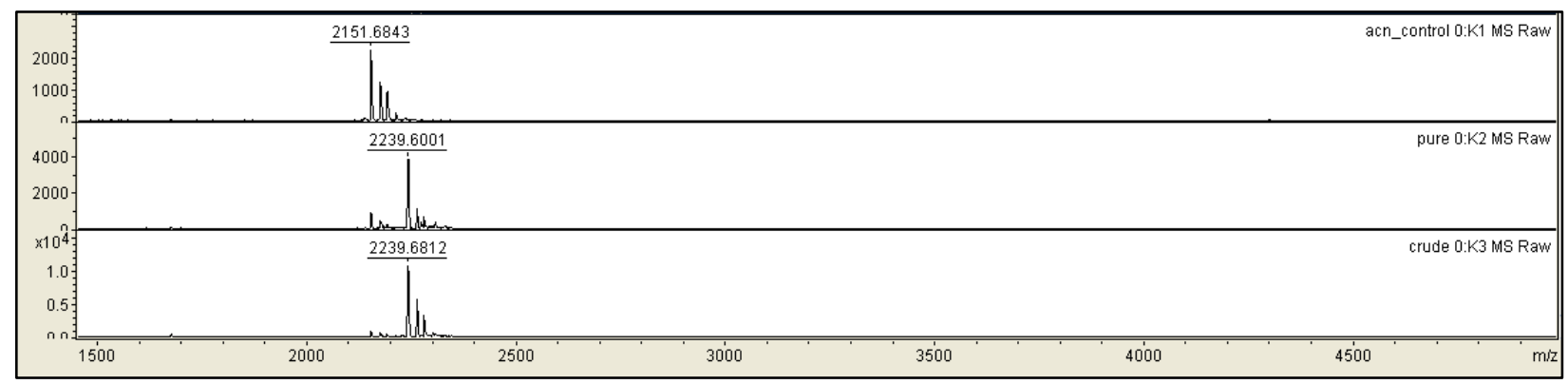

Figure S17: Alkylated peptide with pure and crude disulfide. Acetonitrile control is at the top. Alkylated mass with pure DS2 is in the middle, and alkylated mass with crude DS2 is shown at the bottom.

Table S9: Disulfide (DS) alkylation test reaction masses - Pure DS2.

\begin{tabular}{|c|c|c|}
\hline Compound & Expected Mass $[\mathbf{M + H}]^{+}$ & Observed Mass $[\mathbf{M + H}]^{+}$ \\
\hline Starting Peptide (Free Thiol) & 2150.913 & 2151.684 \\
\hline Peptide + DS Product (Pure) & 2238.948 & 2239.681 \\
\hline Change in mass & 88.035 & 87.997 \\
\hline
\end{tabular}


Table S10: Disulfide (DS) alkylation test reaction masses - Crude DS2.

\begin{tabular}{|c|c|c|}
\hline Compound & Expected Mass $[\mathbf{M + H}]^{+}$ & ${\text {Observed Mass }[\mathbf{M}+\mathbf{H}]^{+}}^{+}$ \\
\hline Starting Peptide (Free Thiol) & 2150.913 & 2151.684 \\
\hline Peptide + DS Product (Crude) & 2238.948 & 2239.948 \\
\hline Change in mass & 88.035 & 88.264 \\
\hline
\end{tabular}

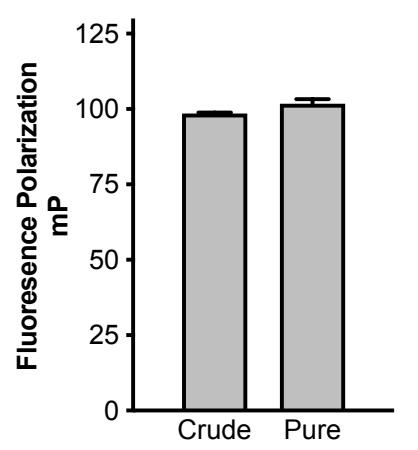

Figure S18: Crude versus pure disulfide results. Alkylation of the Bcs to $C$ peptide with crude DS2 versus pure DS2. 
M. Screening Assay Results

Bcs to C Screen using peptide HBS I_850_Screen

A)

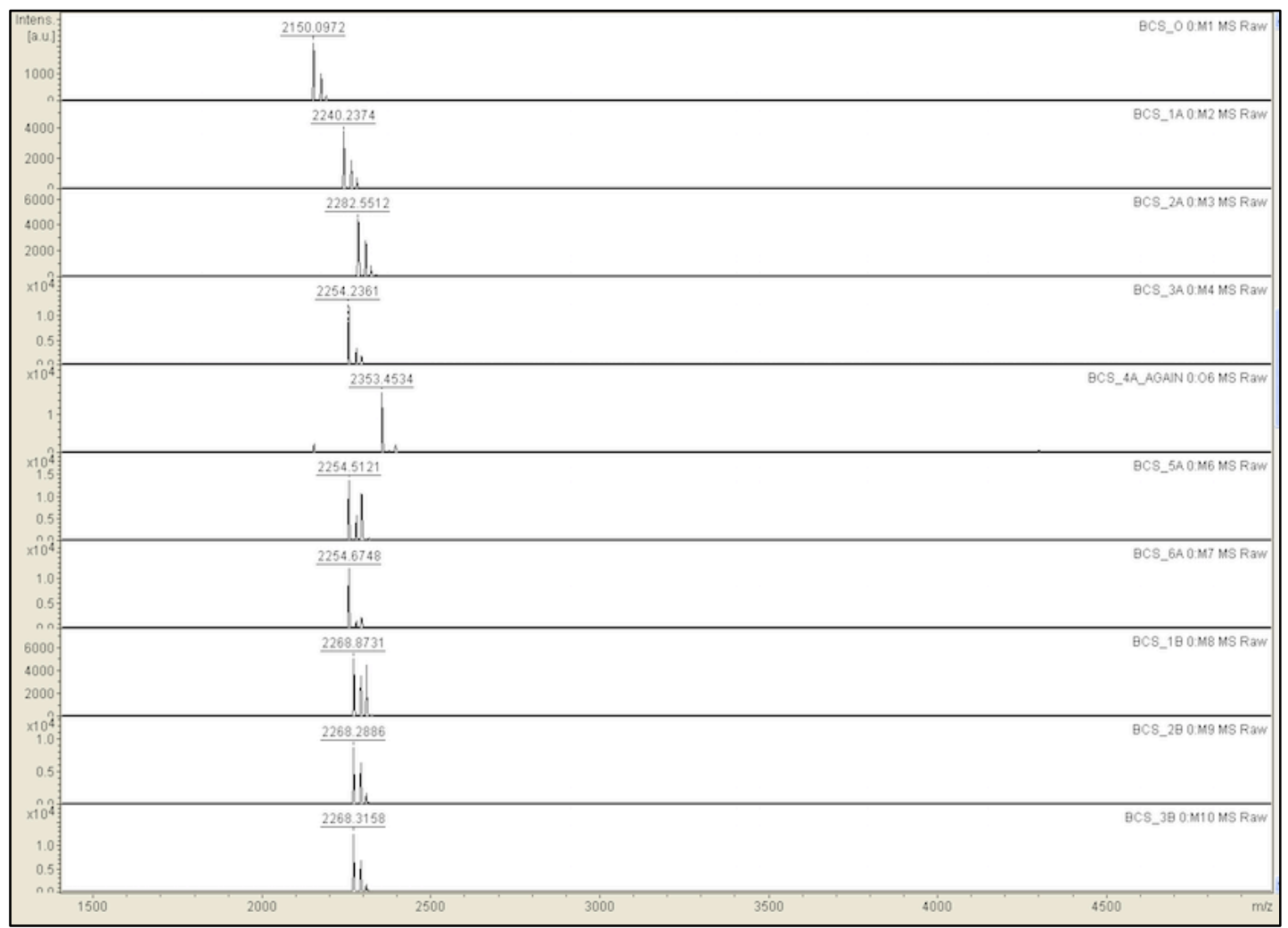

Figure S19: A) MALDI data showing alkylation of HBS I_850_Screen with fragments. 
B)

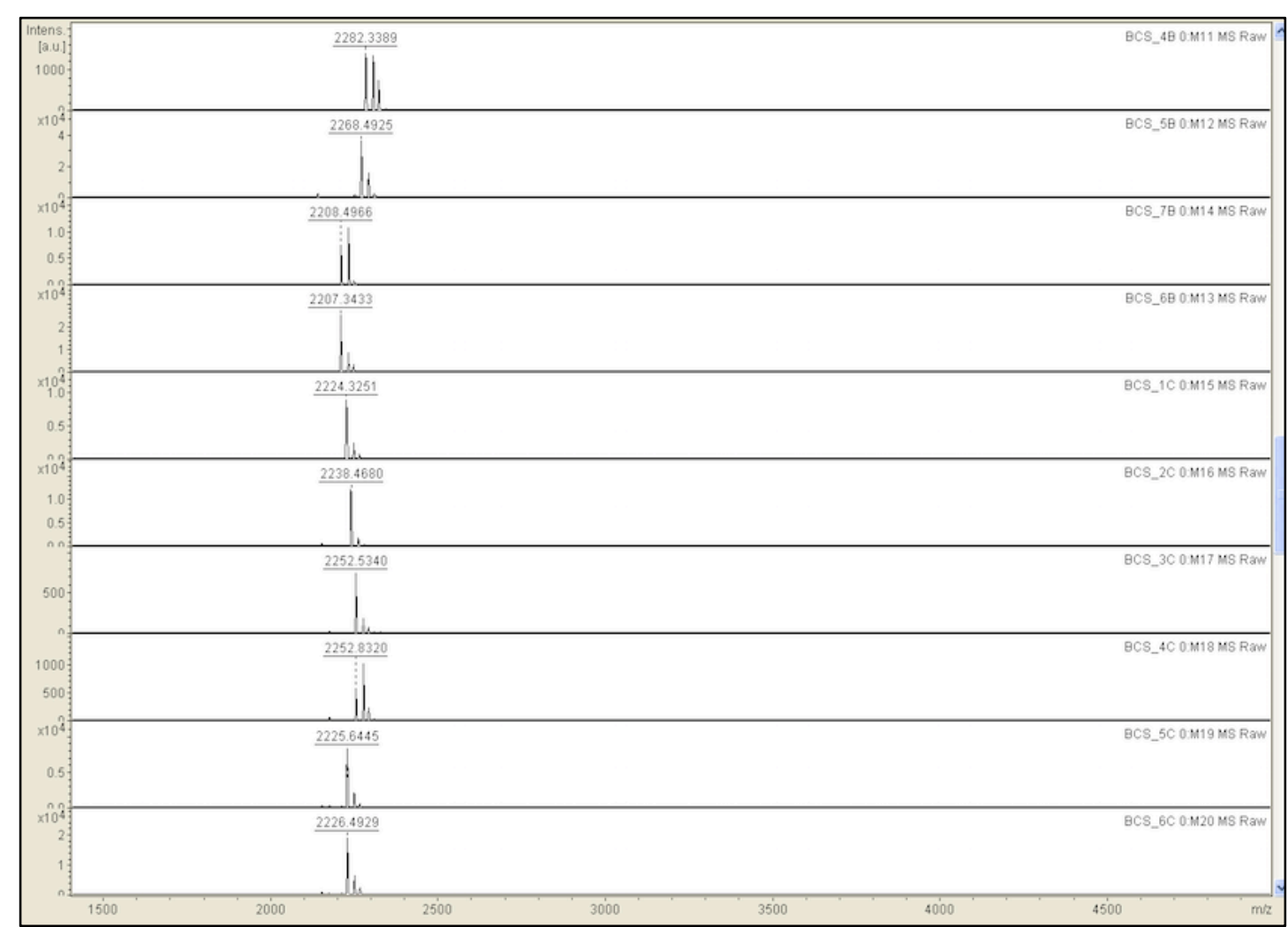

C)

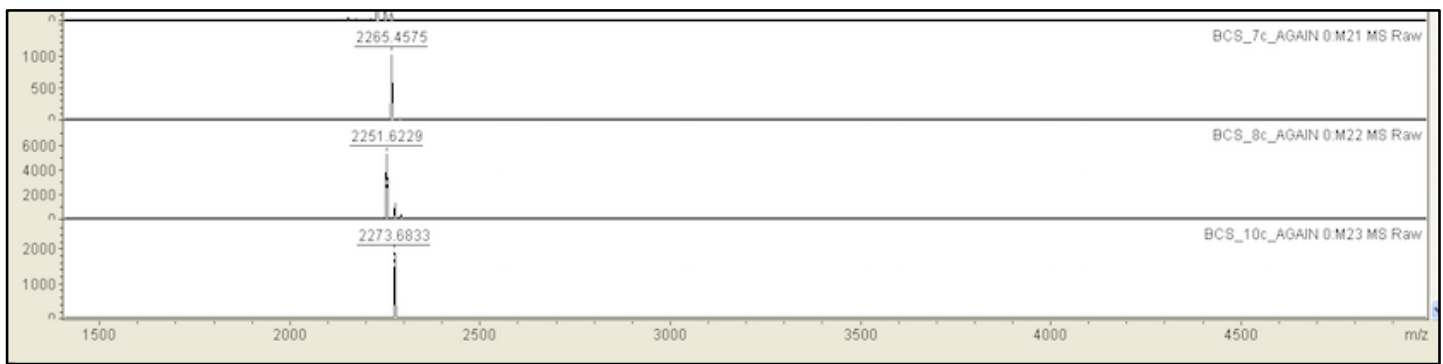

Figure S19: B-C) MALDI data showing alkylation of HBS I_850_Screen with fragments cont. 
Table S11: MALDI summary of Bcs to C. Screen at 850 .

\begin{tabular}{|c|c|c|}
\hline Fragment & $\begin{array}{c}\text { Expected } \\
\text { Mass }[\mathrm{M}+\mathrm{H}]^{+}\end{array}$ & $\begin{array}{c}\text { Observed } \\
\text { Mass }[\mathrm{M}+\mathrm{H}]^{+}\end{array}$ \\
\hline $\begin{array}{c}0-\text { No } \\
\text { Alkylator }\end{array}$ & 2150.913 & 2150.097 \\
\hline 1 & 2240.960 & 2240.237 \\
\hline 2 & 2283.007 & 2282.551 \\
\hline 3 & 2254.976 & 2254.236 \\
\hline 4 & 2353.085 & 2353.453 \\
\hline 5 & 2254.976 & 2254.512 \\
\hline 6 & 2254.976 & 2254.675 \\
\hline 7 & 2268.991 & 2268.873 \\
\hline 8 & 2268.991 & 2268.289 \\
\hline 9 & 2268.991 & 2268.316 \\
\hline 10 & 2283.007 & 2282.339 \\
\hline 11 & 2268.991 & 2268.493 \\
\hline 12 & 2208.919 & 2208.497 \\
\hline 13 & 2207.935 & 2207.343 \\
\hline 14 & 2224.932 & 2224.364 \\
\hline 15 & 2238.948 & 2238.468 \\
\hline 16 & 2252.964 & 2252.534 \\
\hline 17 & 2252.964 & 2252.832 \\
\hline 18 & 2225.927 & 2225.645 \\
\hline 19 & 2226.912 & 2226.493 \\
\hline 20 & 2264.964 & 2265.458 \\
\hline 21 & 2250.948 & 2251.623 \\
\hline 22 & 2272.932 & 2273.683 \\
\hline
\end{tabular}


Y to $C$ Screen using peptide HBS I_857_Screen

A)

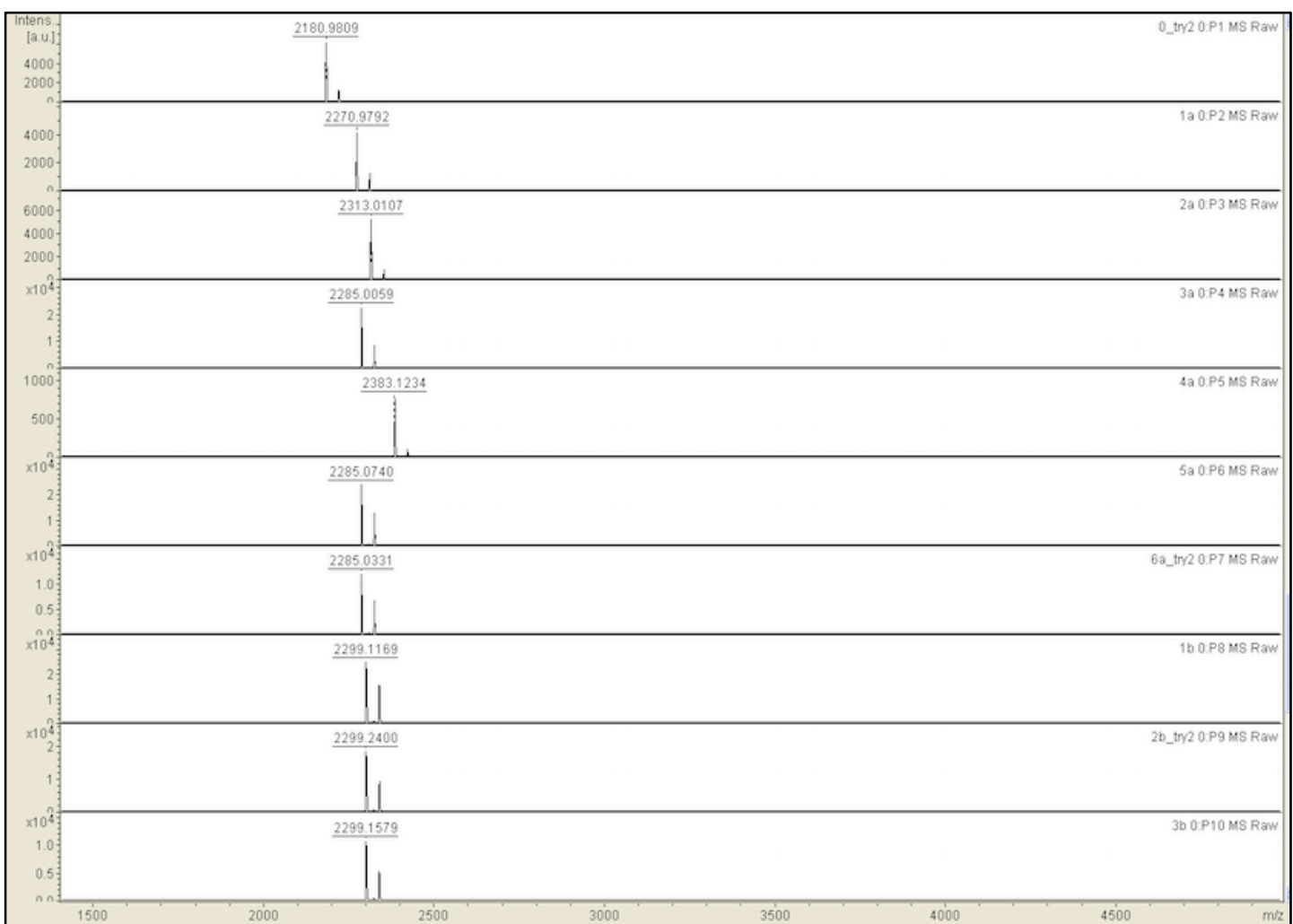

Figure S20: A) MALDI data showing alkylation of HBS I_857_Screen with fragments. 
B)

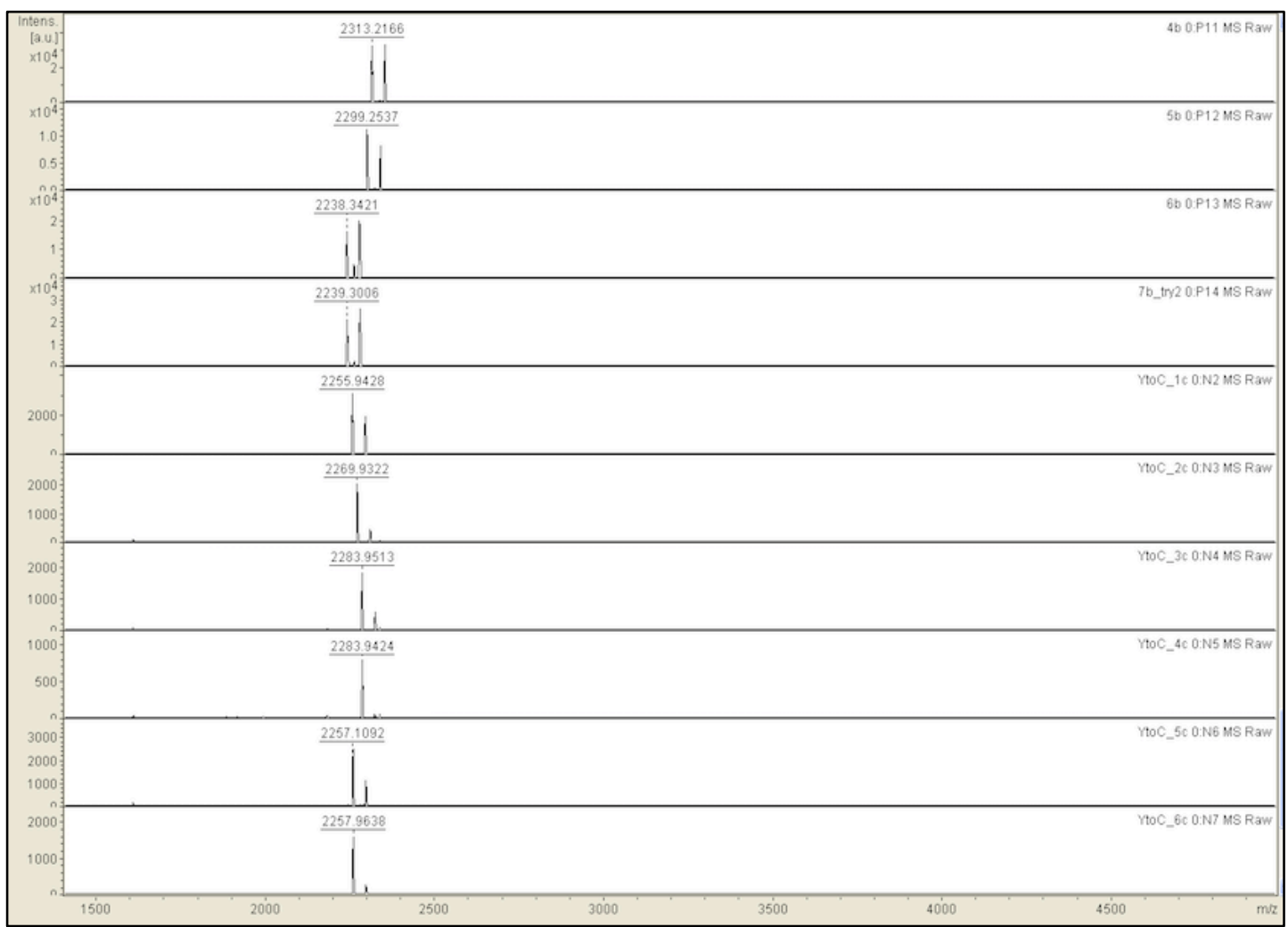

C)

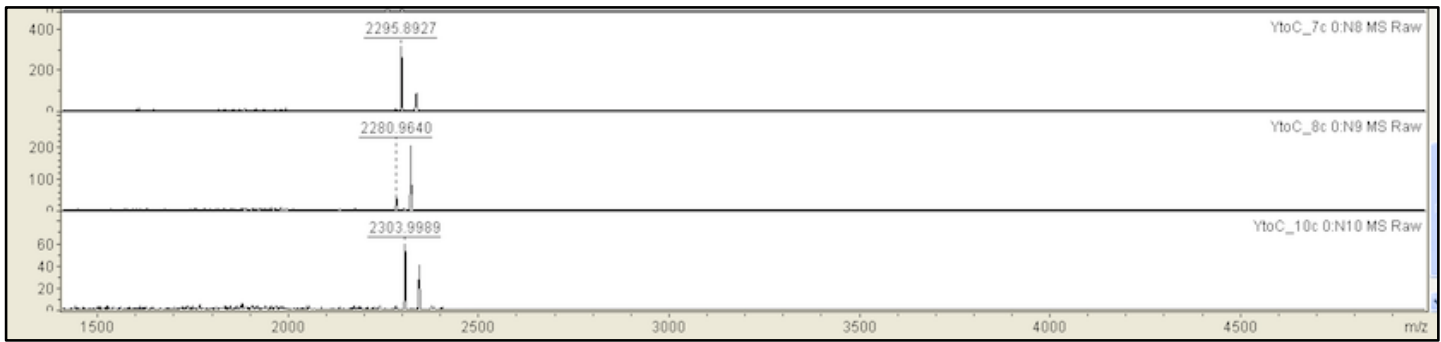

Figure S20: B-C) MALDI data showing alkylation of HBS I_857_Screen with fragments cont. 
Table S12: MALDI summary of $Y$ to $C$. Screen at 857.

\begin{tabular}{|c|c|c|}
\hline Fragment & $\begin{array}{c}\text { Expected } \\
\text { Mass } \\
{[\mathbf{M}+]^{+}}\end{array}$ & $\begin{array}{c}\text { Observed }^{+} \\
\text {Mass } \\
{[\mathbf{M}+]^{+}}\end{array}$ \\
\hline $\begin{array}{c}{ }^{+}-\text {No } \\
\text { Alkylator }\end{array}$ & 2180.906 & 2180.981 \\
\hline 1 & 2270.953 & 2270.979 \\
\hline 2 & 2313.000 & 2313.011 \\
\hline 3 & 2284.969 & 2285.006 \\
\hline 4 & 2383.078 & 2383.123 \\
\hline 5 & 2284.969 & 2285.074 \\
\hline 6 & 2284.969 & 2285.033 \\
\hline 7 & 2298.984 & 2299.117 \\
\hline 8 & 2298.984 & 2299.240 \\
\hline 9 & 2298.984 & 2299.158 \\
\hline 10 & 2313.000 & 2313.217 \\
\hline 11 & 2298.984 & 2299.254 \\
\hline 12 & 2238.911 & 2238.342 \\
\hline 13 & 2237.927 & 2239.301 \\
\hline 14 & 2254.925 & 2255.943 \\
\hline 15 & 2268.941 & 2269.932 \\
\hline 16 & 2282.956 & 2283.951 \\
\hline 17 & 2282.956 & 2283.942 \\
\hline 18 & 2255.920 & 2257.109 \\
\hline 19 & 2256.904 & 2257.964 \\
\hline 20 & 2294.956 & 2295.893 \\
\hline 21 & 2280.941 & 2280.964 \\
\hline 22 & 2302.925 & 2303.999 \\
\hline & & \\
\hline
\end{tabular}


P to $C$ Screen using peptide HBS I_858_Screen

A)

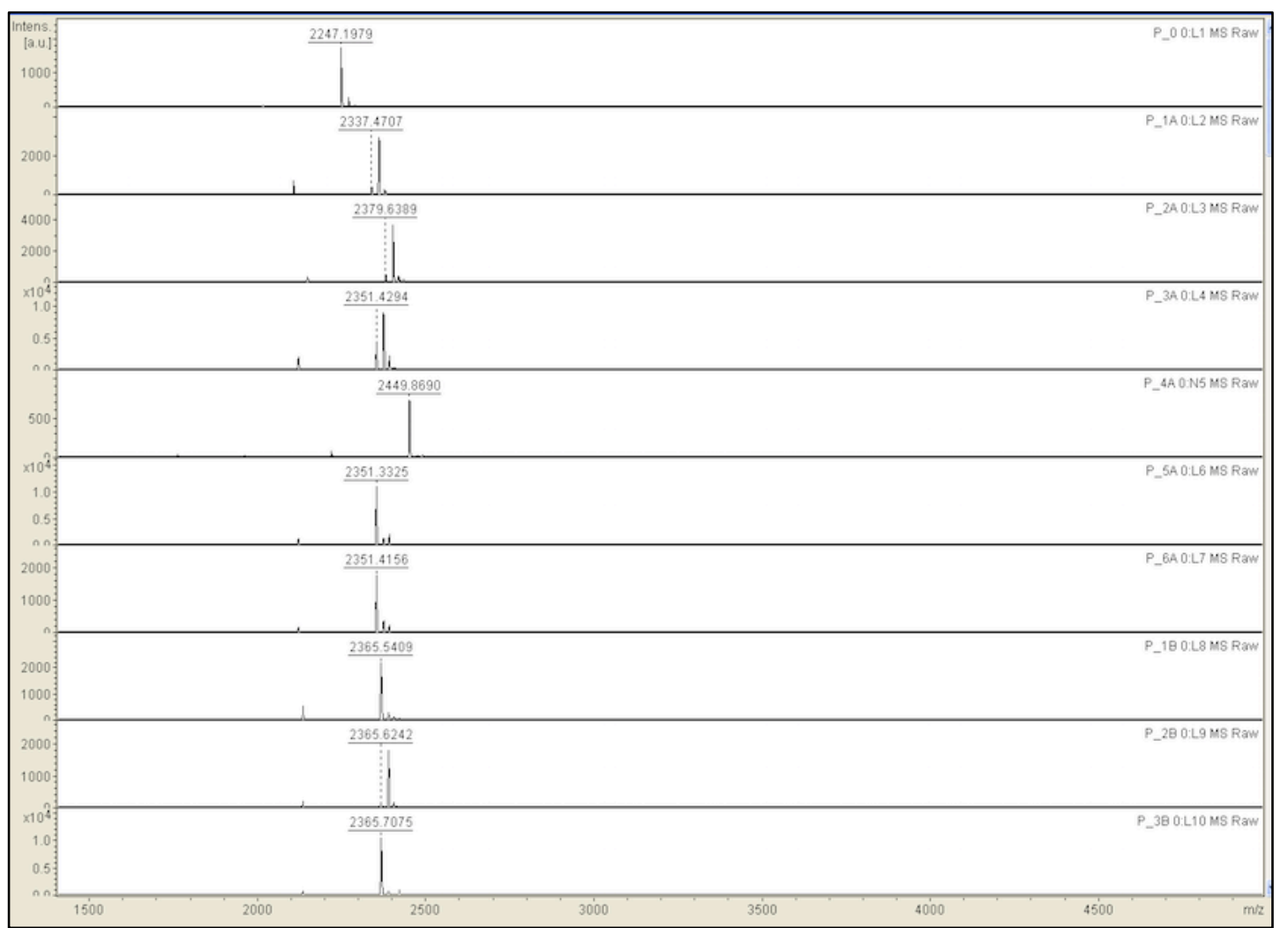

Figure S21: A) MALDI data showing alkylation of HBS I_858_Screen with fragments. 
B)

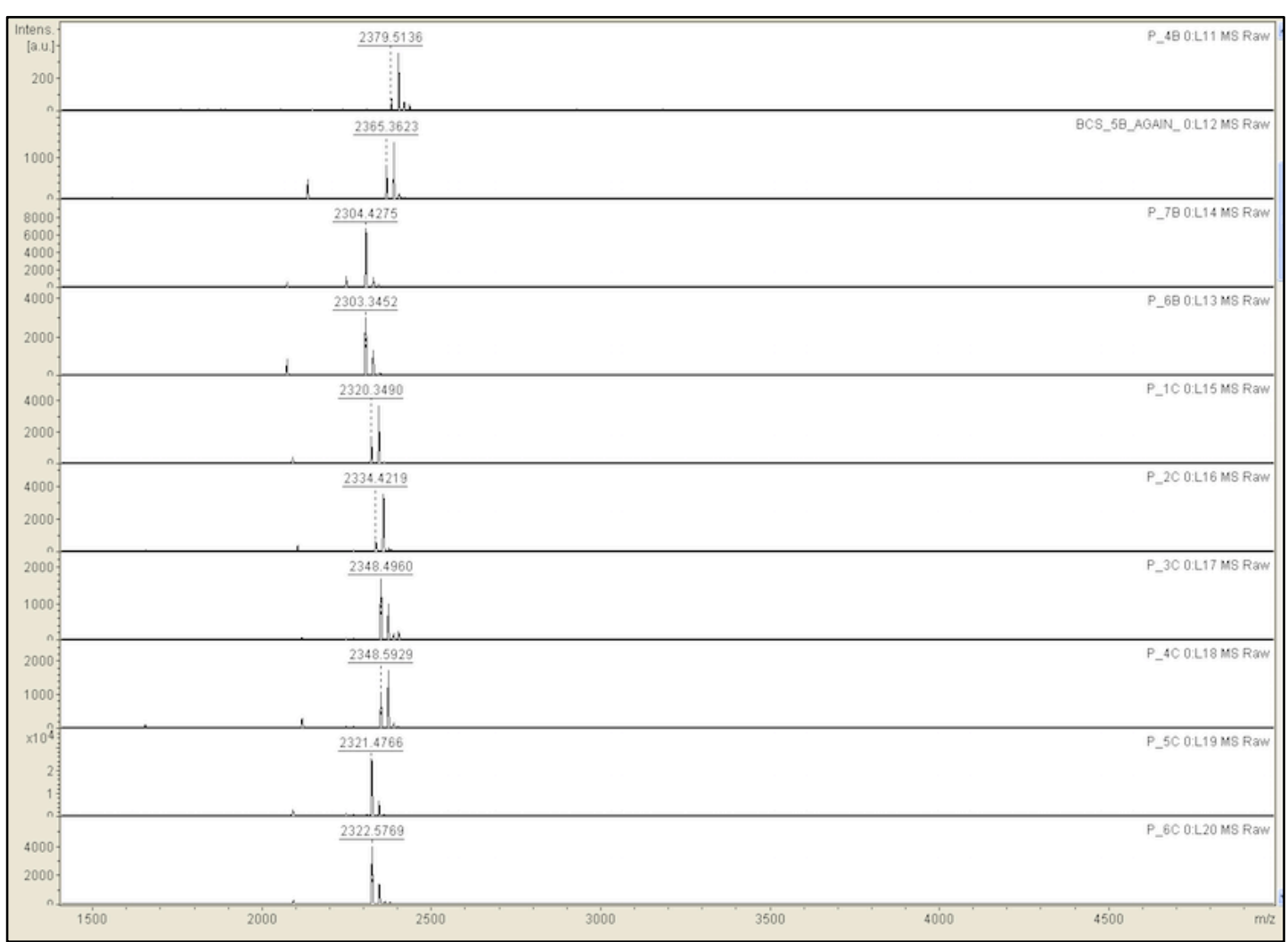

C)

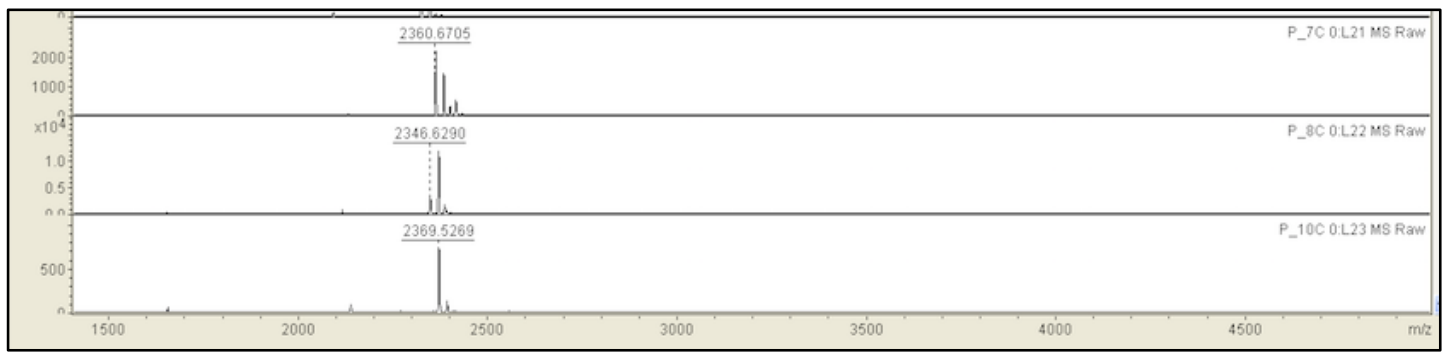

Figure S21: B-C) MALDI data showing alkylation of HBS I_858_Screen with fragments cont. 
Table S13: MALDI summary of $P$ to $C$. Screen at 850.

\begin{tabular}{|c|c|c|}
\hline Fragment & $\begin{array}{c}\text { Expected } \\
\text { Mass } \\
{[\mathbf{M}+]^{+}}\end{array}$ & $\begin{array}{c}\text { Observed } \\
\text { Mass } \\
{[\mathbf{M}+]^{+}}\end{array}$ \\
\hline $\begin{array}{c}{ }^{+} \text {- No } \\
\text { Alkylator }\end{array}$ & 2246.917 & 2247.198 \\
\hline 1 & 2336.963 & 2337.471 \\
\hline 2 & 2379.010 & 2379.639 \\
\hline 3 & 2350.979 & 2351.429 \\
\hline 4 & 2449.089 & 2449.869 \\
\hline 5 & 2350.979 & 2351.333 \\
\hline 6 & 2350.979 & 2351.416 \\
\hline 7 & 2364.995 & 2365.541 \\
\hline 8 & 2364.995 & 2365.624 \\
\hline 9 & 2364.995 & 2365.708 \\
\hline 10 & 2379.010 & 2379.514 \\
\hline 11 & 2364.995 & 2365.362 \\
\hline 12 & 2304.922 & 2304.428 \\
\hline 13 & 2303.938 & 2303.345 \\
\hline 14 & 2320.936 & 2320.349 \\
\hline 15 & 2334.951 & 2334.422 \\
\hline 16 & 2348.967 & 2348.496 \\
\hline 17 & 2348.967 & 2348.593 \\
\hline 18 & 2321.931 & 2321.477 \\
\hline 19 & 2322.915 & 2322.577 \\
\hline 20 & 2360.967 & 2360.671 \\
\hline 21 & 2346.951 & 2346.629 \\
\hline 22 & 2368.936 & 2369.527 \\
\hline & & \\
\hline
\end{tabular}




\section{N. Designs of Cell-Stable Analogues from Screening Hits}

Disulfide bonds were replaced with aliphatic linkages for cyclohexane and cyclopentane hits (Figure S22A and B), and the iodoacetic acid hit had no modifications (Figure S22C)

A)

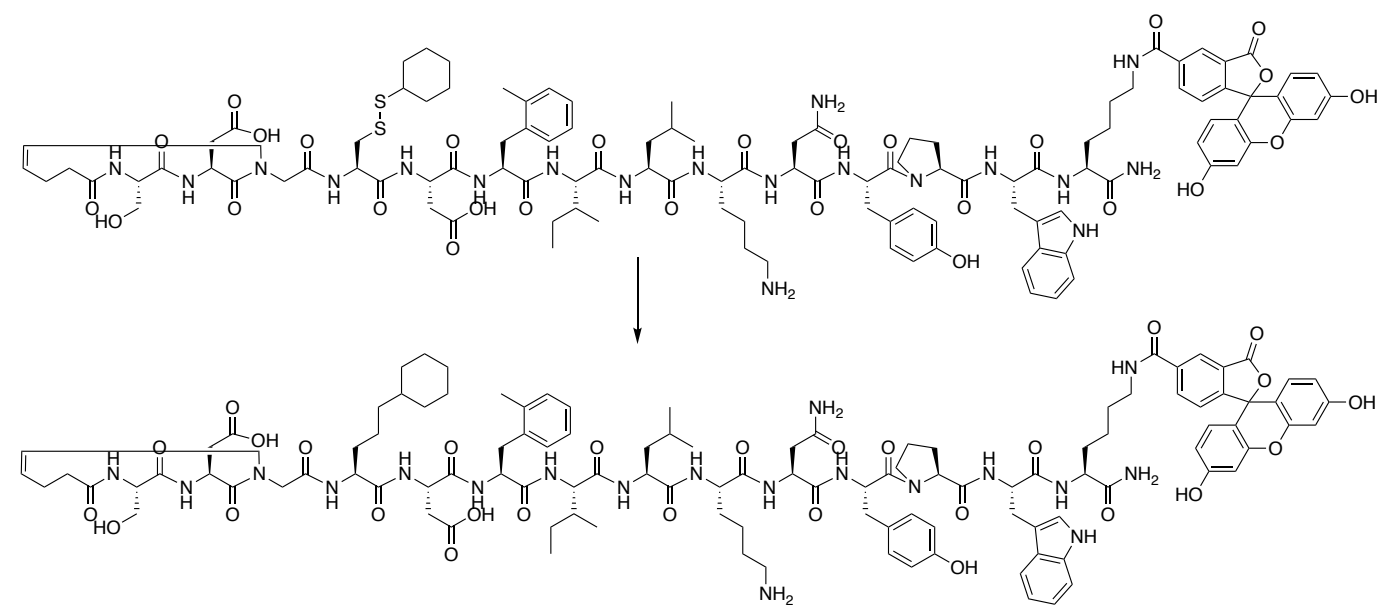

B)

C)
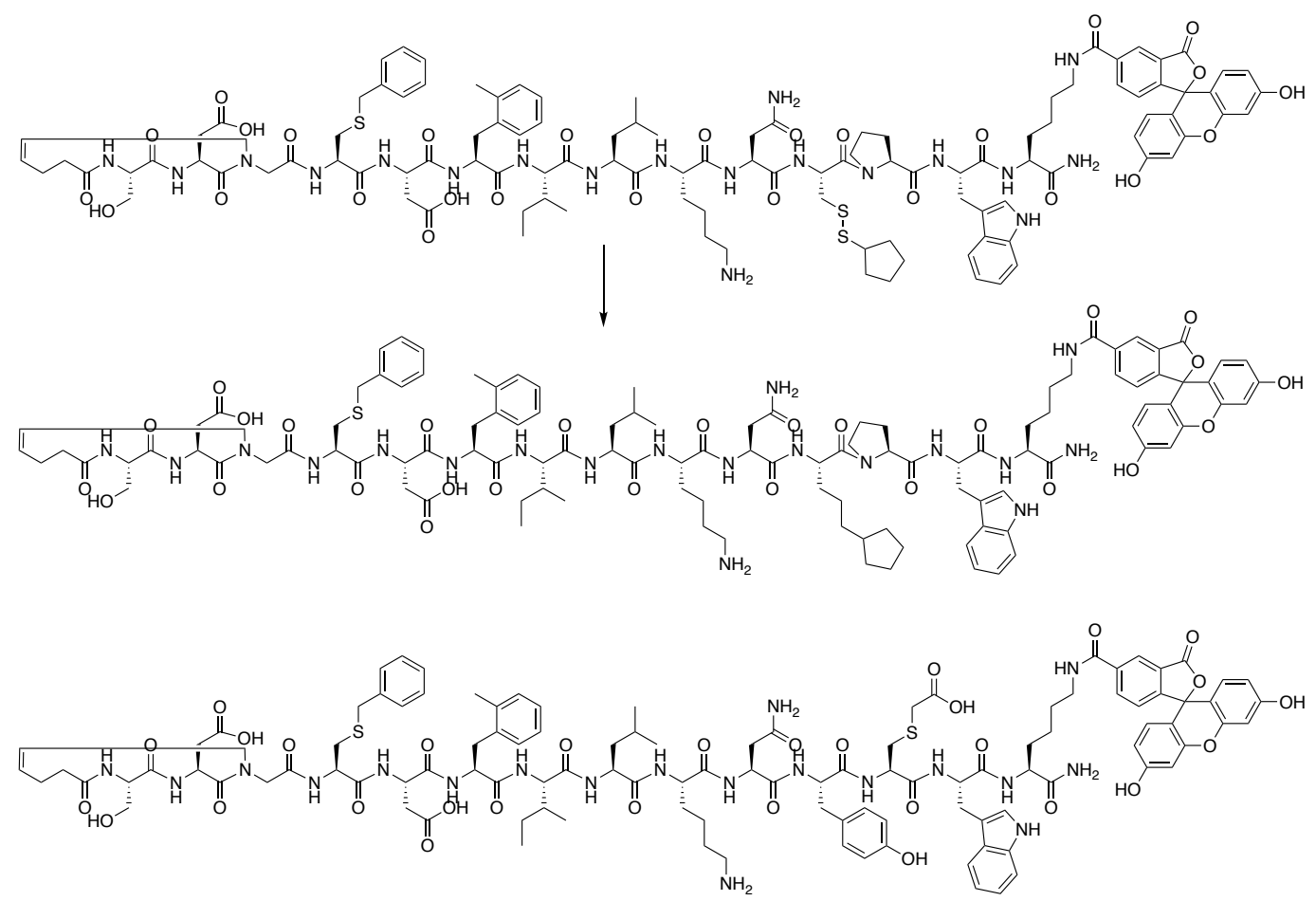

Figure S22: Design of stable analogues. (A) Top: hit from screen at the 850 Bcs position. Bottom: cell-stable analogue HBS III*. (B) Top: hit from screen at the $857 \mathrm{Y}$ position. Bottom: cell-stable analogue HBS IV*. (C) Hit from screen at the $858 \mathrm{P}$ position. Bottom: cell-stable analogue HBS $\mathrm{V}^{*}$. 


\section{O. Supplemental References:}

1. Rooklin, D., et al., Targeting Unoccupied Surfaces on Protein-Protein Interfaces. J Am Chem Soc, 2017. 139(44): p. 15560-15563.

2. Patgiri, A., S.T. Joy, and P.S. Arora, Nucleation effects in peptide foldamers. J Am Chem Soc, 2012. 134(28): p. 11495-502.

3. Joy, S.T. and P.S. Arora, An optimal hydrogen-bond surrogate for alpha-helices. Chem Commun (Camb), 2016. 52(33): p. 5738-41.

4. Miller, S.E., P.F. Thomson, and P.S. Arora, Synthesis of hydrogen-bond surrogate alpha-helices as inhibitors of protein-protein interactions. Curr Protoc Chem Biol, 2014. 6(2): p. 101-116.

5. Subiros-Funosas, R., A. El-Faham, and F. Albericio, Aspartimide formation in peptide chemistry: occurrence, prevention strategies and the role of $\mathrm{N}$-hydroxylamines. Tetrahedron, 2011. 67(45): p. 8595-8606.

6. Henchey, L.K., et al., High specificity in protein recognition by hydrogen-bond-surrogate alpha-helices: selective inhibition of the p53/MDM2 complex. Chembiochem, 2010. 11(15): p. 2104-7.

7. Lao, B.B., et al., Rational design of topographical helix mimics as potent inhibitors of protein-protein interactions. J Am Chem Soc, 2014. 136(22): p. 7877-88.

8. Roehrl, M.H., J.Y. Wang, and G. Wagner, A general framework for development and data analysis of competitive high-throughput screens for small-molecule inhibitors of protein-protein interactions by fluorescence polarization. Biochemistry, 2004. 43(51): $p$. 16056-66.

9. Gee, C.T., E.J. Koleski, and W.C. Pomerantz, Fragment Screening and Druggability Assessment for the CBP/p300 KIX Domain through Protein-Observed 19F NMR Spectroscopy. Angewandte Chemie International Edition, 2015. 54(12): p. 3735-3739.

10. Majmudar, C.Y., et al., Sekikaic acid and lobaric acid target a dynamic interface of the coactivator CBP/p300. Angewandte Chemie, 2012. 124(45): p. 11420-11424.

11. Williamson, M.P., Using chemical shift perturbation to characterise ligand binding. Progress in nuclear magnetic resonance spectroscopy, 2013. 73: p. 1-16.

12. Kuil, J., et al., Cell permeable ITAM constructs for the modulation of mediator release in mast cells. Org Biomol Chem, 2011. 9(3): p. 820-33.

13. Kelleman, A., et al., Incorporation of thioether building blocks into an alphavbeta3specific RGD peptide: synthesis and biological activity. Biopolymers, 2003. 71(6): p. 68695. 